\title{
REVIEW OF SODIUM EFFECTS ON CANDIDATE MATERIALS FOR CENTRAL RECEIVER SOLAR-THERMAL POWER SYSTEMS
}

\author{
by \\ O. K. Chopra, J. Y. N. Wang, \\ and K. Natesan
}

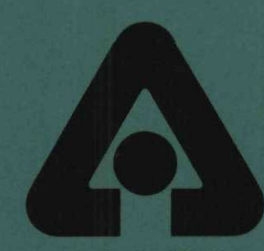

U OfC-AUA-USDOE

ARGONNE NATIONAL LABORATORY, ARGONNE, ILLINOIS Prepared for the U. S. DEPARTMENT OF ENERGY under Contract W-31-109-Eng-38 
The facilities of Argonne National Laboratory are owned by the United States Government. Under the terms of a contract (W-31-109-Eng-38) among the U. S. Department of Energy, Argonne Universities Association and The University of Chicago, the University employs the staff and operates the Laboratory in accordance with policies and programs formulated, approved and reviewed by the Association.

\section{MEMBERS OF ARGONNE UNIVERSITIES ASSOCIATION}

The University of Arizona Carnegie-Mellon University Case Western Reserve University The University of Chicago University of Cincinnati Illinois Institute of Technology University of Illinois Indiana University The University of Iowa Iowa State University
The University of Kansas Kansas State University Loyola University of Chicago Marquette University The University of Michigan Michigan State University University of Minnesota University of Missouri Northwestern University University of Notre Dame
The Ohio State University

Ohio University

The Pennsylvania State University

Purdue University

Saint Louis University

Southern Illinois University

The University of Texas at Austin

Washington University

Wayne State University

The University of Wisconsin-Madison

\section{-NOTICE}

This report was prepared as an account of work sponsored by an agency of the United States Government. Neither the United States nor any agency thereof, nor any of their employees, makes any warranty, expressed or implied, or assumes any legal liability or responsibility for any third party's use or the results of such use of any information, apparatus, product or process disclosed in this report, or represents that its use by such third party would not infringe privately owned rights. Mention of commercial products, their manufacturers, or their suppliers in this publication does not imply or connote approval or disapproval of the product by Argonne National Laboratory or the United States Government.

Printed in the United States of America

Available from

National Technical Information Service

U. S. Department of Commerce

5285 Port Royal Road

Springfield, VA 22161

NTIS price codes

Printed copy: A03

Microfiche copy: A01 


\section{DISCLAIMER}

This report was prepared as an account of work sponsored by an agency of the United States Government. Neither the United States Government nor any agency Thereof, nor any of their employees, makes any warranty, express or implied, or assumes any legal liability or responsibility for the accuracy, completeness, or usefulness of any information, apparatus, product, or process disclosed, or represents that its use would not infringe privately owned rights. Reference herein to any specific commercial product, process, or service by trade name, trademark, manufacturer, or otherwise does not necessarily constitute or imply its endorsement, recommendation, or favoring by the United States Government or any agency thereof. The views and opinions of authors expressed herein do not necessarily state or reflect those of the United States Government or any agency thereof. 


\section{DISCLAIMER}

Portions of this document may be illegible in electronic image products. Images are produced from the best available original document. 
Distribution Category:

Solar Thermal-Large Scale

Systems (UC-62c)

ANL-79-36

\section{ARGONNE NATIONAL LABORATORY \\ 9700 South Cass Avenue \\ Argonne, Illinois 60439}

\section{REVIEW OF SODIUM EFFECTS ON CANDIDATE MATERIALS \\ FOR CENTRAL RECEIVER SOLAR-THERMAL POWER SYSTEMS}

by

O. K. Chopra, J. Y. N. Wang, and K. Natesan

\section{Materials Science Division}

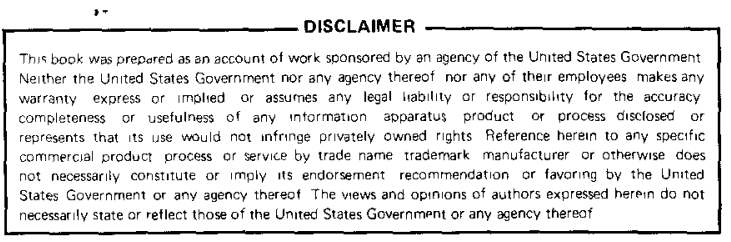

July 1979 
TABLE OF CONTENTS

Page

ABSTRACT . . . . . . . . . . . . . . . . . . 8

I. INTRODUCTION ...................... 8

II. BEHAVIOR OF FERRITIC STEELS IN SODIUM . . . . . . . . . . 10

A. Corrosion ................. . 10

B. Interstitial Transfer . . . . . . . . . . . . 12

C. Mechanical Properties................ 17

III. BEHAVIOR OF AUSTENITIC STAINLESS STEELS IN SODIUM . . . . . . 25

A. Corrosion . . . . . . . . . . . . . . . 26

B. Interstitial Transfer. . . . . . . . . . . . 27

C. Mechanical Properties.............. . 33

IV. BEHAVIOR OF ALLOY 800 IN SODIUM . . . . . . . . . . . 40

A. Corrosion . . . . . . . . . . . . . . 40

B. Interstitial Transfer . . . . . . . . . . . . . 42

C. Mechanical Properties. . . . . . . . . . . . 43

V. SPECIAL CONSIDERATIONS . . . . . . . . . . . . . . . 44

A. Tube Wastage by $\mathrm{Na}_{2} \mathrm{O}$ Reactions ... . . . . . . . 44

B. Therma1-striping Phenomena . . . . . . . . . . 47

VI. RECOMMENDATIONS FOR FUTURE WORK . . . . . . . . . . . . 49

REFERENCES . . . . . . . . . . . . . . . . . . . 49

APPENDIX . . . . . . . . . . . . . . . . . . . . 60

A. List of Abbreviations . . . . . . . . . . . . 60

B. Temperature Conversion Table ............ 61 
LIST OF FIGURES

No.

Page

1. Effect of Temperature on the Corrosion Rate of Ferritic

Steels in Flowing Sodium . . . . . . . . . . . . .

2. Carbon Activity-Concentration Relationship for $\mathrm{Fe}-2 \frac{1}{4} \mathrm{Cr}-1 \mathrm{Mo}$

Steel at Temperatures between 823 and $1023 \mathrm{~K}$ (Ref. 1) . . .

3. Carbon Activity-Concentration Relationships for $\mathrm{Fe}-9 \mathrm{Cr}-\mathrm{Mo}$ Steel at Temperatures between 773 and $973 \mathrm{~K}$; (a) High-purity Steels, (b) Commercial Steels (Ref. 21) ..........

4. Temperature Dependence of Decarburization Rate Constants for $\mathrm{Fe}-2 \frac{1}{4} \mathrm{Cr}-1 \mathrm{Mo}$ Steel in Sodium . . . . . . . . . . . .

5. Temperature Dependence of Carburization/Decarburization Rate Constants for Fe-9Cr-Mo Steels in Sodium (Ref. 21) . . . . .

6. Change in Carbon and Nitrogen Concentrations in Normalized and Tempered $\mathrm{Fe}-2 \frac{1}{4} \mathrm{Cr}-1 \mathrm{Mo}$ Steel after Exposure to Flowing Sodium (Ref. 8).........................

7. Nitrogen Concentration-Distance Profiles in Fe-9Cr-Mo Stee1s after Exposure to Flowing Sodium at Temperatures between 773 and $973 \mathrm{~K}$ (Ref. 8,21) ...............

8. Yield and Tensile Strengths for $\mathrm{Fe}-2 \frac{1}{4} \mathrm{Cr}-1 \mathrm{Mo}$ Steels Containing Different Bulk Carbon Concentrations . . . . . . . . . .

9. Yield and Tensile Strengths for $\mathrm{Fe}-2 \frac{1}{4} \mathrm{Cr}-1$ Mo Steels after Decarburization in Sodium . . . . . . . . . . . . .

10. Tensile Strength of Decarburized $\mathrm{Fe}-2 \frac{1}{4} \mathrm{Cr}-1 \mathrm{Mo}$ Steel as a Function of Bulk Carbon Concentration (Ref. 31) . . . . . . 20

11. Larson-Miller Parameter Diagram for $\mathrm{Fe}-2 \frac{3}{4} \mathrm{Cr}-1 \mathrm{Mo}$ Stee1s Containing Different Bulk Carbon Concentrations . . . . . . . .

12. Creep-rupture Strength for $\mathrm{Fe}-2 \frac{1}{4} \mathrm{Cr}-1 \mathrm{Mo}$ Steel as a Function of Bulk Carbon Concentration . . . . . . . . . . . .

13. Relation between Loss of Carbon due to Decarburization in

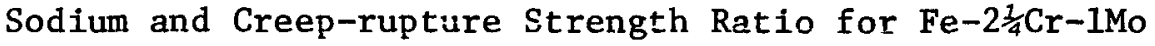
Steel

14. Change in Carbon Concentration and Creep-rupture Strength for Fe-2 $\frac{3}{5} \mathrm{Cr}-1 \mathrm{Mn}$ Steel as a Function of Wall Thickness . . . . .

15. Fatigue-1ife Curves for $\mathrm{Fe}-2 \frac{3}{4} \mathrm{Cr}-1 \mathrm{Mo}$ Steel Tested in Sodium at (a) $755 \mathrm{~K}$ and (b) $811 \mathrm{~K}$ 
LIST OF FIGURES

No.

$\underline{\text { Page }}$

16. Effect of Temperature on the (a) Yield and (b) Ultimate Strengths of Fer9Cr-Mo Steels . . . . . . . . . . .

17. Stressmrupture Curves for Fe-9Cr-Mo Steels at (a) $811 \mathrm{~K}$ and

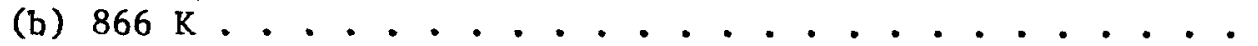

18. Fatiguenlife Curves for Fe-9Cr-1Mo Steel Tested in Air and Helium Environments (Ref. 50) .............

19. Effect of Temperature on the Corrosion Rate of Type 316

Stainless Steel in Flowing Sodium . . . . . . . . . . .

20. Effective Diffusion Coefficients for Carbon Transfer in Austenitic and Ferritic Steels in a Sodium Environment . .

21. Carburization-Decarburization Regimes for Types 316 and 304 Stainless Steel Relative to the Carbon Concentration in Sodium and Temperature (Ref. 73) ............

22. Effect of Temperature on the Carburization-Decarburization Behavior of Austenitic Stainless Steels......... . 30-31

23. Relationship between Carbon Contamination Rate of FFTF and EBR-II Primary Systems and the Steady-state Carbon Concentration in the Sodium (Ref. 73) . . . . . . . . . .

24. Effective Diffusion Coefficient for Nitrogen Transfer in Austenitic Stainless Steels in a Sodium Environmert. . . .

25. Effect of Sodium Exposure on the Ultimate Tensile Strength of (a) Type 304 and (b) Type 316 Stainless Steels (Ref. 78) . .

26. Effect of Sodium Exposure on the Uniform Elongation of (a) Type 304 and (b) Type 316 Stainless Steels (Ref. 78) • . 34

27. Effect of Sodium Exposure on the Total Elongation of (a) Type 304 and (b) Type 316 Stainless Steels (Ref. 78) . . . . .

28. Variation of Time to Rupture and Minimum Creep Rate with Applied Stress for Type 304 Stainless Steel at 973, 923, and $873 \mathrm{~K}$. . . . . . . . . . . . . . . . .

29. Variation of Time to Rupture and Minimum Creep Rate with Applied Stress for Type 316 Stainless Stee1 at 973, 923, 873,

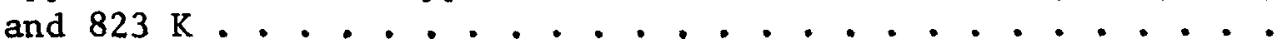




\section{LIST OF FIGURES}

№.

$\underline{\text { Page }}$

30. Fatiguenlife Curves for Types 304 and 316 Stainless Steel Tested in Air and Sodium at Temperatures between 811 and $973 \mathrm{~K}$ (Refs. 91-95)................ 38-39

31. Fatigue Crack-propagation Behavior of Annealed Type 304 Stainless Steel in Sodium at $700 \mathrm{~K}$ (Ref. 96) . . . . . . 40

32. Corrosion-rate Data for Alloy 800 in Flowing Sodium at Temperatures between 870 and $990 \mathrm{~K}$. . . . . . . . .

33. Microstructures of Several Alloys after Exposure to Flowing Sodium for $15,726 \mathrm{~h}$ at $980 \mathrm{~K}$ (Ref. 105) . . . . . . . .

34. Relationship between Depth of Intergranular Penetration and Exposure Time for Alloy 800 (Ref. 105) . . . . . . .

35. Carbon Activity-Concentration Relationship for Alloy 800 at Temperatures between 866 and $1033 \mathrm{~K}$ (Ref. 108) . . . . .

36. Creep-rupture Behavior of Alloy 800 in Sodium and Argon Environments ....................

37. Log Penetration Rate versus Reciprocal Jet Temperature for (a) $\mathrm{Fe}-2 \frac{1}{4} \mathrm{Cr}-1 \mathrm{Mo}$ Steel and (b) $\mathrm{Fe}-2 \frac{1}{4} \mathrm{Cr}-1 \mathrm{Mo}$ Steel and Stainless Steel (Ref. 117) . . . . . . . . . . . . 46

38. Self-enlargement of Microleaks with Time (Ref. 116)..... 48 
No.

I. Materials Selection for Various Components of Sodiumcooled Reactors...................... 9

II. Composition of Ferritic Steels . . . . . . . . . . . . . . 14

III. Wastage Resistance of Candidate Materials Relative to the Fen2 $\frac{1}{4} \mathrm{Cr}-1$ Mo Alloy at $733 \mathrm{~K}$ (Ref. 116)........... 46

IV. Penetration Rate and Comparative Wastage Resistance of Candidate Materials (Ref. 118) 


\title{
REVIEW OF SODIUM EFFECTS ON CANDIDATE MATERIALS \\ FOR CENTRAL RECEIVER SOLAR-THERMAL POWER SYSTEMS
}

O. K. Chopra, J. Y. N. Wang, and K. Natesan

\begin{abstract}
Available information on the corrosion behavior and mechanical properties of structural materials in a high-temperature sodium environment has been reviewed to compile a data base for selection of materials for advanced central-receiver solar-power systems, for which sodium is being considered as a heat-transfer fluid and thermalstorage medium. Candidate materials for this application (e.g., Types 304, 316, and 321 stainless steel, Alloy 800, and $\mathrm{Fe}-2 \frac{1}{4} \mathrm{Cr}-1 \mathrm{Mo}$ and $\mathrm{Fe}-9 \mathrm{Cr}-1 \mathrm{Mo}$ ferritic steels) have been used in the construction of various components for liquidmetal fast-breeder reactors in this country and abroad with considerable success. Requirements for additional information on material properties in a sodium environment are identified. The additional data coupled with more quantitative deformation models, failure criteria, and component design rules will further reduce uncertainties in the assessment of performance limits and component reliability in large sodium heat-transport systems.
\end{abstract}

\section{INTRODUCTION}

Sodium is being considered as a heat-transfer fluid and thermalstorage medium in advanced solar central-receiver power systems, which can produce electric power when coupled with sodium-to-water steam generators and conventional turbines. The broad technology base that has been developed in liquid-metal fast-breeder reactor (LMFBR) programs in this country and abroad over the past 25 years can be applied in the design, materials selection, and construction of components for solar centralreceiver systems. Information relative to the thermal-hydraulic performance of sodium-heated steam generators, the reliability and performance of large sodium pumps, flow meters, and valves, and requirements for sodium-purity control and monitoring equipment is readily available and directly applicable to the development of solar-power systems.

The purpose of this report is to review the status of work on the corrosion behavior and mechanical properties of structural materials in a high-temperature sodium environment. In general, the criteria for selection of materials for use in a sodium-cooled solar-power system are similar to those in LMFBR systems, i.e., the materials must possess adequate strength at high temperatures, compatibility with the sodium and water/steam environments, and resistance to chloride and caustic stresscorrosion cracking. Fabricability, weldability, cost, and material 
availability are other considerations that influence material selection. Special requirements such as resistance to swelling and embrittlement under neutron irradiation and friction and self-welding characteristics in a liquid-sodium environment, which are important in the LMFBR, can be disregarded for the present application.

Based upon the above requirements, the influence of sodium environment on the composition, microstructure, and mechanical behavior of a number of iron-base alloys has been investigated in considerable detail. In addition to temperature, sodium purity, and exposure time, the effect of different alloys (e.g., austenitic and ferritic steels) in the circuit on corrosion behavior and material performance has been evaluated. Commercially avallable alloys for which information on performance in a sodium environment has been well documented include Types 304 and 316 stainless steel, Fe-2 $\frac{1}{4} \mathrm{Cr}-1$ Mo steel (unstabilized and stabilized grades), and to a limited extent, Type 321 stainless steel, Alloy 800 and $\mathrm{Fe}-9 \mathrm{Cr}-1 \mathrm{Mo}$ steel. These materials have been selected for construction of various components in breeder reactors in operation or under construction in the US, UK, USSR, FRG, France, and Japan (see Table I).

TABLE I. Materials Selected for Various Components of Sodium-cooled Reactors

\begin{tabular}{|c|c|c|c|c|c|}
\hline \multirow[b]{2}{*}{ Country } & \multirow[b]{2}{*}{ Reactor } & \multirow[b]{2}{*}{ Vesse1 } & $\begin{array}{c}\text { IHX } \\
\text { (Intermed late }\end{array}$ & \multicolumn{2}{|c|}{ Steam Generator } \\
\hline & & & Heat Exchanger) & Evaporator & Superheater \\
\hline \multirow[t]{2}{*}{ US } & $\begin{array}{l}\text { Ferm1 } \\
\text { EBR-II }\end{array}$ & $\begin{array}{l}304 \\
304\end{array}$ & $\begin{array}{l}304 \\
304\end{array}$ & $\begin{array}{l}\mathrm{Fe}-2 \frac{1}{4} \mathrm{Cr}-1 \mathrm{Mo} \\
\mathrm{Fe}-2 \frac{1}{4} \mathrm{Cr}-1 \mathrm{Mo}\end{array}$ & $\begin{array}{l}\mathrm{Fe}-2 \frac{1}{4} \mathrm{Cr}-1 \mathrm{Mo} \\
\mathrm{Fe}-2 \frac{3}{4} \mathrm{Cr}-1 \mathrm{Mo}\end{array}$ \\
\hline & $\begin{array}{l}\text { FFTF } \\
\text { CRBRP }\end{array}$ & $\begin{array}{l}304 \\
304\end{array}$ & $\begin{array}{l}316 \\
304\end{array}$ & $\stackrel{\mathrm{Fe}-2 \frac{1}{4} \mathrm{Cr}-1 \mathrm{Mo}}{ }$ & $\stackrel{\mathrm{Fe}-2 \frac{1}{4} \mathrm{Cr}-1 \mathrm{Mo}}{a}$ \\
\hline UK & $\begin{array}{l}\text { DFR } \\
\text { PFR }\end{array}$ & $\begin{array}{l}316 \\
321\end{array}$ & $\begin{array}{l}316 \\
321\end{array}$ & $\frac{321}{\mathrm{Fe}-2 \frac{1}{4} \mathrm{Cr}-1 \mathrm{Mo}-\mathrm{Nb}}$ & $\begin{array}{l}321 \\
316 \mathrm{H}\end{array}$ \\
\hline \multirow[t]{2}{*}{ USSR } & BOR-60 & 304 & 304 & $\begin{array}{l}\mathrm{Fe}-2 \frac{1}{4} \mathrm{Cr}-1 \mathrm{Mo} \\
(\mathrm{A} 110 \text { y } 800)\end{array}$ & $\mathrm{Fe}-2 \frac{1}{4} \mathrm{Cr}-1 \mathrm{Mo}$ \\
\hline & $\begin{array}{l}B N-350 \\
B N-600\end{array}$ & $\begin{array}{l}304 \\
304\end{array}$ & $\begin{array}{l}304 \\
304\end{array}$ & $\begin{array}{l}\mathrm{Fe}-2 \frac{1}{4} \mathrm{Cr}-1 \mathrm{Mo} \\
\mathrm{Fe}-2 \frac{1}{4} \mathrm{Cr}-1 \mathrm{Mo}\end{array}$ & $\begin{array}{c}\mathrm{Fe}-2 \frac{1}{4} \mathrm{Cr}-1 \mathrm{Mo} \\
304\end{array}$ \\
\hline FRG & SNR-300 & 304 & $\mathrm{Fe}-2 \frac{1}{4} \mathrm{Cr}-1 \mathrm{Mo}-1 \mathrm{Nb}$ & $\mathrm{Fe}-2 \frac{1}{4} \mathrm{Cr}-1 \mathrm{Mo}-\mathrm{Nb}$ & $\mathrm{Fe}-2{ }^{3} \mathrm{Cr}-1 \mathrm{Mo}-\mathrm{Nb}$ \\
\hline FRANCE & $\begin{array}{l}\text { Rapsodie } \\
\text { Phenix } \\
\text { Creys-Malville }\end{array}$ & $\begin{array}{l}316 \mathrm{~L} \\
316 \mathrm{~L} \\
316\end{array}$ & $\begin{array}{l}316 \\
316 \\
316\end{array}$ & $\begin{array}{l}\mathrm{a} \\
\mathrm{Fe}-2 \frac{1}{4} \mathrm{Cr}-1 \mathrm{Mo}-1 \mathrm{Nb} \\
\mathrm{A} 11 \text { y } 800 \text { tubes } \\
304,316 \mathrm{~L} \text { she11 }\end{array}$ & $\begin{array}{l}a \\
321 \\
b\end{array}$ \\
\hline JAPAN & $\begin{array}{l}\text { JOYO } \\
\text { Monju }\end{array}$ & $\begin{array}{l}304 \\
304\end{array}$ & $\begin{array}{l}304 \\
304\end{array}$ & $\stackrel{\mathrm{a}}{\mathrm{Fe}-2 \frac{1}{4} \mathrm{Cr}-1 \mathrm{Mo}}$ & $\begin{array}{l}a \\
304\end{array}$ \\
\hline
\end{tabular}

\footnotetext{
a Sodium to air heat exchanger

${ }^{b}$ Evaporator and superheater are combined in a single unit.
} 
Base-line mechanical-properties data for most of these materials are available in ASME Boiler and Pressure Vessel Codes and the Nuclear Systems Materials Handbook (NSMH); however, information pertaining to corrosion and the effect of sodium environment on mechanical behavior is primarily contained in proceedings of liquid-metal-technology conferences and journal publications within the past 15 years. The major results of this work are summarized in the following sections. Recent data obtained from bilateral exchange agreements between US-DOE and organizations in other countries involved in the development of fast-breeder reactors cannot be referenced in this review.

\section{BEHAVIOR OF FERRITIC STEELS IN SODIUM}

Low-alloy $\mathrm{Fe}-2 \frac{1}{4} \mathrm{Cr}-1 \mathrm{Mo}$ ferritic steel has been favored internationally for use in the construction of sodium-heated steam generators on the basis of its high thermal conductivity, resistance to stresscorrosion cracking in both chloride- and caustic-contaminated environments, established fabrication techniques, and cost. A major concern for this application is the susceptibility of the steel to decarburization when exposed to high-temperature flowing sodium. 1-3 The carbon loss from the material leads to a significant reduction in elevated-temperature mechanical strength. 4-5 Furthermore, in sodium systems which contain austenitic and ferritic components, decarburization of the ferritic material leads to carburization of the austenitic stainless steels. ${ }^{6-8}$

Ferritic steels with higher chromium content, e.g., 9 wt \% chromium with 1-2 wt \% molybdenum, have been proposed for both steam evaporator and superheater units to minimize the extent of carbon transfer in bimetallic sodium heat-transport systems. The high-chromium ferritic steels provide a greater resistance to carbon transfer 9,10 and possess adequate elevatedtemperature mechanical properties.

\section{A. Corrosion}

The corrosion behavior of $\mathrm{Fe}-2 \frac{1}{4} \mathrm{Cr}-1$ Mo steel has been studied ${ }^{8}, 11-16$ over the temperature range from 720 to $920 \mathrm{~K} *$ at oxygen levels between $\sim 1$ and $\sim 25 \mathrm{ppm}$. The results show that the corrosion behavior is sensitive to changes in temperature, oxygen content in the sodium, and sodium velocity. The corrosion rate increases with an increase in sodium velocity up to $\sim 7 \mathrm{~m} / \mathrm{s}$, at which point the corrosion rate becomes velocity independent. At a given temperature the dependence of corrosion rate on oxygen concentration in sodium is of the form [0] ${ }^{\mathrm{n}}$, where $\mathrm{n}$ is $\sim 2$. After an initial period, which tends to be variable, the metal-loss rates attain a steadystate value and remain constant with time for given sodium-purity and operating conditions. The metallurgical condition of the steel does not have a significant effect on the steady-state corrosion rates.

* Conversion factor: degree Celsius = Kelvin -273 , degree Fahrenheit = Kelvin x 1,8 $\rightarrow 459,9$. See Appendix B for Conversion Table. 
The temperature dependence of corrosion rate for $\mathrm{Fe}-2 \frac{1}{4} \mathrm{Cr}-1 \mathrm{Mo}$ steel is shown in Fig. 1. The curves which are recommended by the NSMH are valid for temperatures below $870 \mathrm{~K}$. The data used to generate these correlations were obtained from samples exposed in the hot leg of sodium loops at sodium velocities $>7 \mathrm{~m} / \mathrm{s}$. Consequent1y, the corrosion rate of $\mathrm{Fe}-2 \frac{7}{4} \mathrm{Cr}-1 \mathrm{Mo}$ steel components exposed in the cold leg (e.g., the steam generators and associated piping of a solar-thermal-electric power plant) will be less than that indicated by the curves. The steam generator lies in a region where net sodium-side deposition would be expected. $8,17,18$ In positions downstream from the high-temperature region of the circuit, dissolution of the steel is minimal because of a reduction in corrosion potential, $i_{\text {.e., the sodium }}$ becomes saturated with respect to the corrosion products.

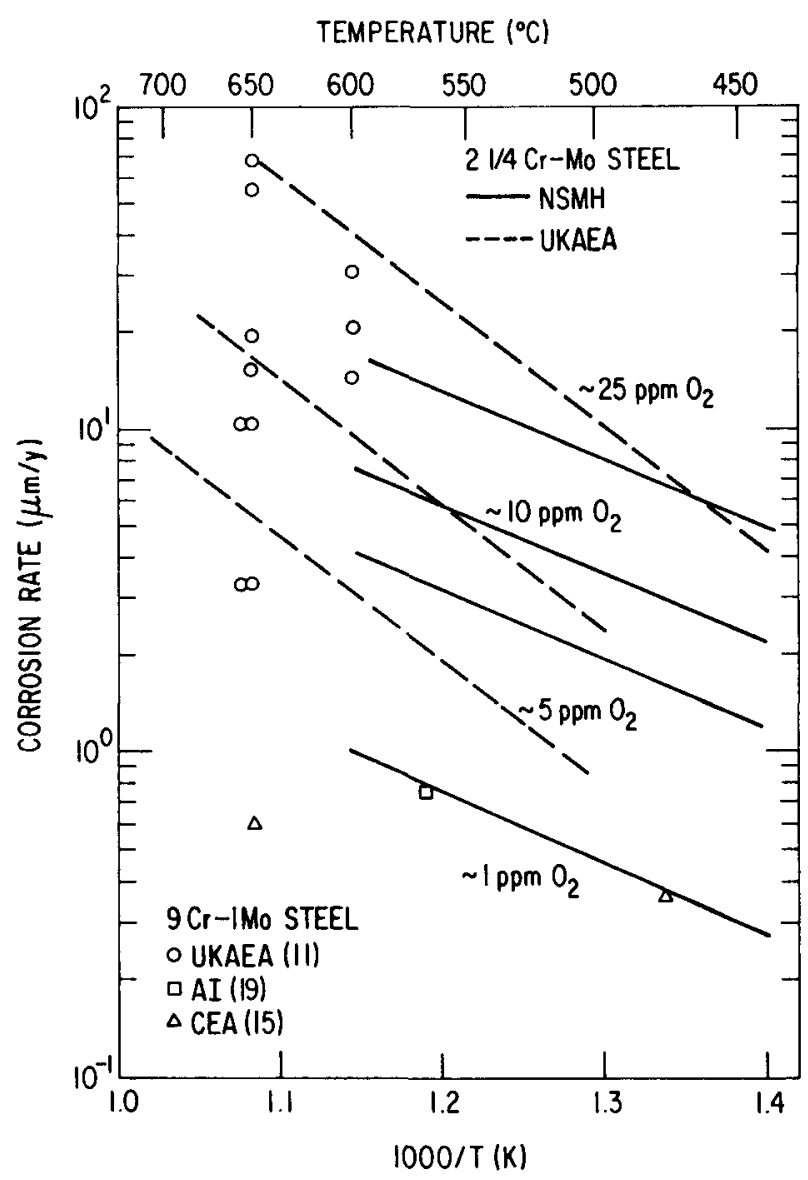

Fig. 1

Effect of Temperature on the Corrosion Rate of Ferritic Steels in Flowing Sodium. ANL Neg. No. 306-79-486.

Information on the corrosion behavior of $\mathrm{Fe}-9 \mathrm{Cr}-\mathrm{Mo}$ steel in a sodium environment is 1imited. $11,15,19$ Results for the steady-state corrosion rate of this steel at temperatures between 750 and $870 \mathrm{~K}$ are also plotted in Fig. 1. In general, the corrosion rate for $\mathrm{Fe}-9 \mathrm{Cr}-\mathrm{Mo}$ steel is lower than that for $\mathrm{Fe}-2 \frac{3}{4} \mathrm{Cr}-1 \mathrm{Mo}$ steel; however, other differences in the corrosion behavior of the two steels have been noted. For example, Fe-9Cr-Mo material is prone to internal oxidation and to the formation of a surface-oxide film when exposed to high-temperature sodium containing 
20-40 ppm* oxygen.11,20 The surface and internal-oxidation behavior depends on the oxygen level and velocity of sodium. Surface oxides may persist for long periods in sodium at velocities of 3 to $4 \mathrm{~m} / \mathrm{s}$. However, at higher velocities, $i . e ., \gtrsim 9 \mathrm{~m} / \mathrm{s}$, the thickness of the surface-oxide film and the depth of internal penetration is relatively small. Surface and internal oxidation is not observed in specimens exposed to low-oxygen sodium, or in specimens placed in downstream locations at lower temperatures. More work is required to establish the corrosion rate and the operating limits for Fe-9Cr-Mo steel.

\section{B. Interstitial Transfer}

Nonmetallic elements such as carbon and nitrogen are known to migrate in monometallic sodium loops as a result of chemical activity differences that occur in nonisothermal systems. Transfer of these elements also occurs in bimetallic sodium loops, i.e., those constructed of austenitic and ferritic steels, due to differences in the chemical activities of these elements in the steels. For normal operating conditions in LMFBR heat-transport circuits the low-alloy $\mathrm{Fe}-2 \frac{1}{4} \mathrm{Cr}-1$ Mo stee 1 tends to decarburize because of an inherently high carbon activity in the steel. The high-chromium Fe-9Cr-Mo steel has a relatively low carbon activity and can either carburize or decarburize depending on the temperature and carbon concentration in sodium.

The carburization/decarburization behavior of ferritic steels can be ascertained from the relationship between equilibrium carbon concentration and carbon activity in steel, shown in Figs. 2 and 3 for $\mathrm{Fe}-2 \frac{3}{4} \mathrm{Cr}-1 \mathrm{Mo}$ (normalized condition) and $\mathrm{Fe}-9 \mathrm{Cr}-\mathrm{Mo}$ (normalized and tempered condition), respectively; The chemical composition of the steels used in these investigations ${ }^{1}, 2 i$ is given in Table II. The results show that the variation in the carbon concentration in steel with carbon activity is fairly insensitive to temperature. At temperatures between $\sim 770$ and $970 \mathrm{~K}$, the equilibrium carbon concentration can be expressed as a function of carbon activity $\left(a_{c}\right)$ by the relation

$$
\ln \mathrm{C}_{2 \frac{7}{4} \mathrm{Cr}-1 \mathrm{Mo}}(\text { wt } \%)=-1.12+0.61 \text { ln } \mathrm{a}_{\mathrm{c}}
$$

for the $\mathrm{Fe}-2 \frac{7}{4} \mathrm{Cr}-1 \mathrm{Mo}$ steel, and

$$
\mathrm{C}_{9 \mathrm{Cr}-\mathrm{Mo}}(\mathrm{wt} \%)=0.16 \mathrm{a}_{\mathrm{c}}{ }^{0.14}+10.5 \mathrm{a}_{\mathrm{c}}^{2.2}
$$

for the Fe-9Cr-Mo steel. The equilibrium relationships indicate that, at a carbon concentration in sodium of $0.05 \mathrm{ppm}$ at $823 \mathrm{~K}$ (which corresponds to a carbon activity of 0.017 in sodium), the $\mathrm{Fe}-2 \frac{1}{4} \mathrm{Cr}-1 \mathrm{Mo}$ and $\mathrm{Fe}-9 \mathrm{Cr}-\mathrm{Mo}$

\footnotetext{
*These oxygen concentrations were obtained by off-line vacuum-distillation techniques and the values are somewhat greater than the actual oxygen concentration in the sodium.
} 


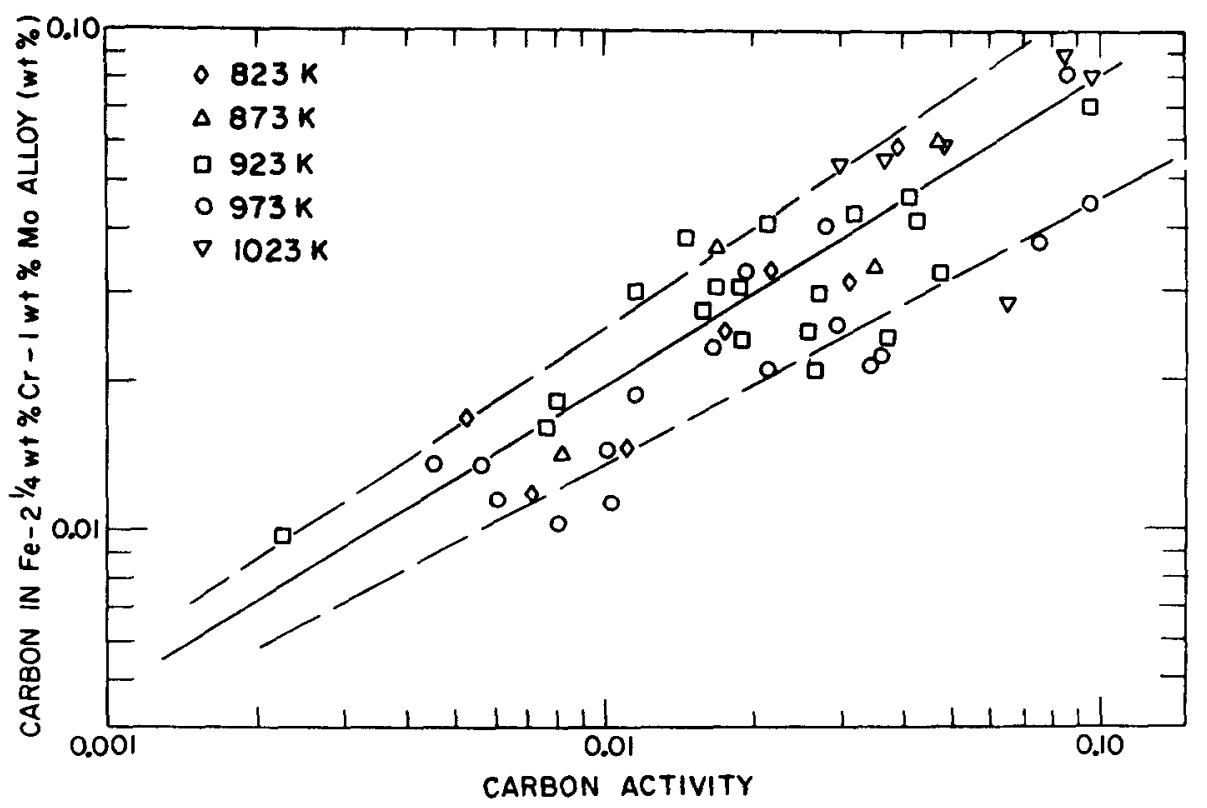

Fig. 2. Carbon Activity-Concentration Relationship for $\mathrm{Fe}-2 \frac{1}{4} \mathrm{Cr}-1 \mathrm{Mo}$ Steel at Temperatures between 823 and $1023 \mathrm{~K}$ (Ref. 1). ANL Neg. No. 306-79-487. Permission has been obtained from the copyright holder for reproduction of this figure.

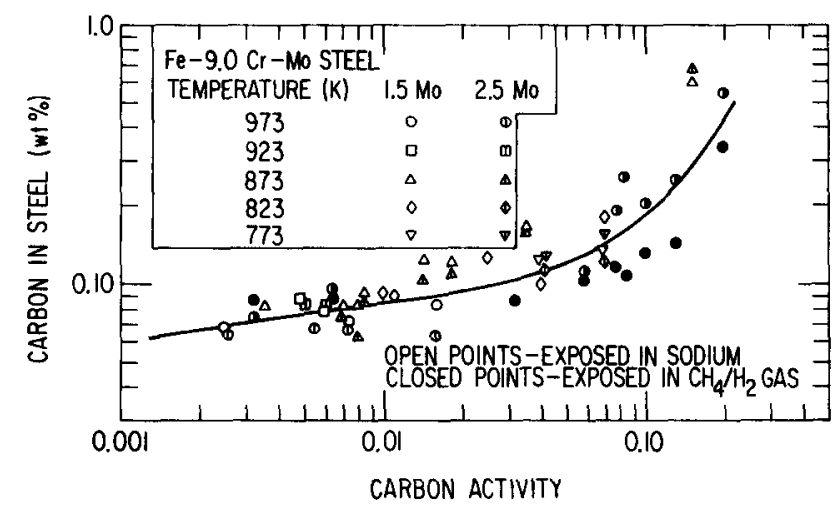

(a)

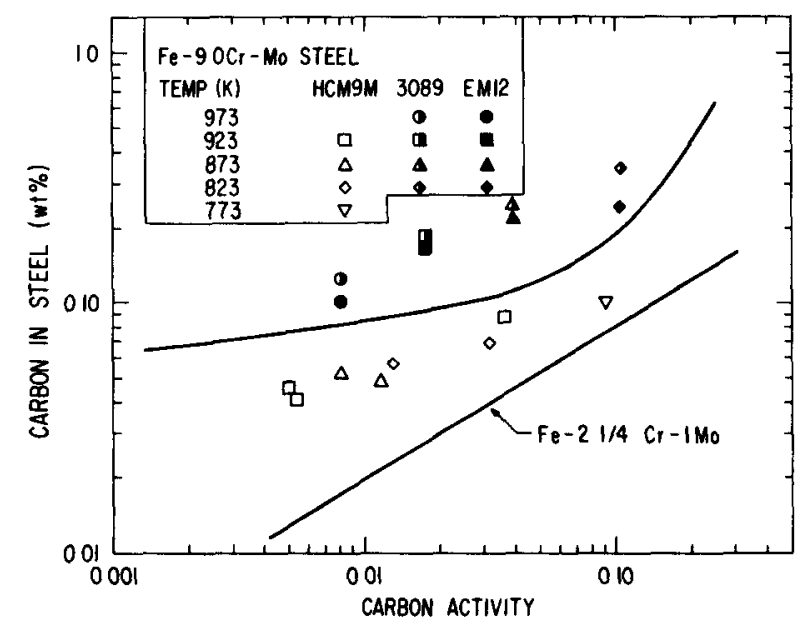

Fig. 3

Carbon Activity-Concentration Relationships for $\mathrm{Fe}-9 \mathrm{Cr}-1 \mathrm{Mo}$ Steel at Temperatures between 773 and $973 \mathrm{~K}$; (a) Highpurity Steels, (b) Commercial Steels (Ref. 21). ANL Neg. Nos. 306-78-907 and 306-78-931 Rev. 1.

(b) 
TABLE II. Composition ${ }^{\text {a }}$ of Ferritic Steels

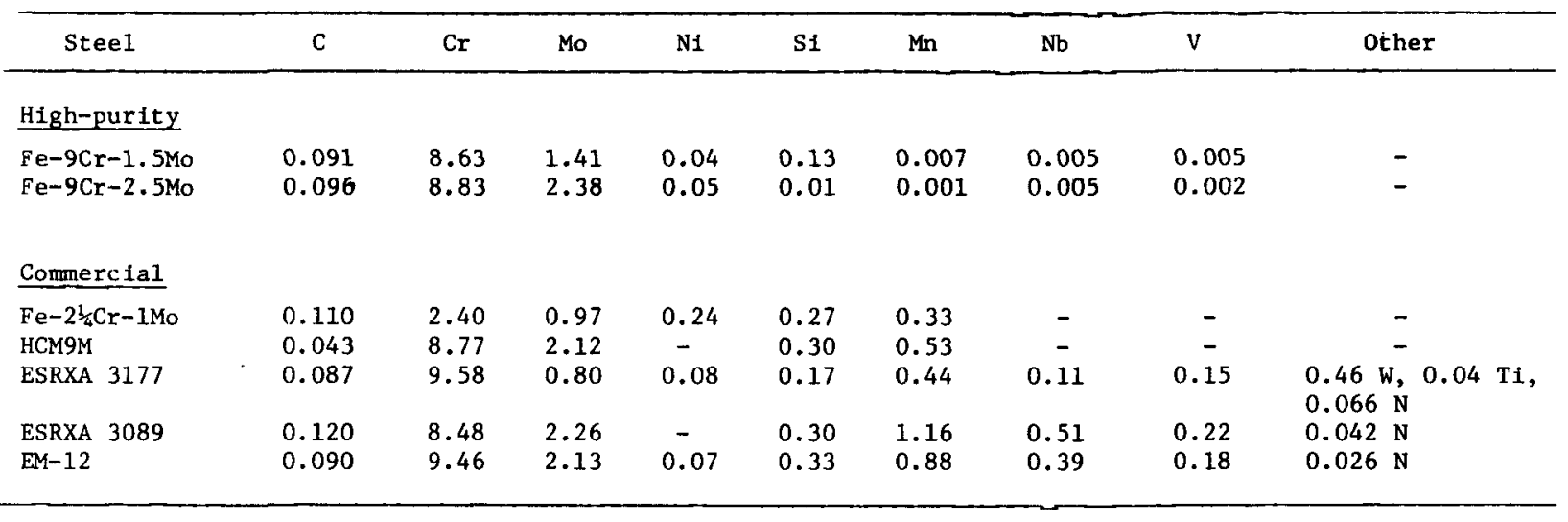

Wt \%

steels would contain $\sim 0.027$ and 0.092 wt \% carbon, respectively. The microstructure as well as the composition of the steel plays an important role in the carburization/decarburization behavior. For example, stabilizing elements such as niobium and vanadium in $\mathrm{Fe}-9 \mathrm{Cr}-\mathrm{Mo}$ steel (e.g., EM-12) increase the equilibrium carbon concentration in the steel for a given carbon activity of the sodium, as shown in Fig. $3 \mathrm{~b}$.

The kinetics of carburization/decarburization of ferritic steels in static and dynamic sodium have been studied by numerous investigators. $11,21-23$ The extent of carburization or decarburization (expressed in terms of carbon loss per unit surface area of the steel, M) is a function of temperature and sodium-exposure time, $t$, as defined by the parabolic relationship

$$
\mathrm{M}=\mathrm{kt} \mathrm{t}^{\frac{1}{2}} \text {, }
$$

where the carburization/decarburization rate constant, $k$, has an exponential dependence on reciprocal absolute temperature.

Krankota and Armijo $0^{2}$ have analyzed available data on the decarburization of $\mathrm{Fe}-2 \frac{3}{4} \mathrm{Cr}-1 \mathrm{Mo}$ steel in sodium and obtained "best fit" and "upper limit" curves for the decarburization rate constant. The upper limit curve as well as some of the more recent data on the decarburization of Fe-2 $\frac{1}{4} \mathrm{Cr}-1 \mathrm{Mo}$ steel are shown in Fig. 4. The scatter in the results arises from differences in the carbon-activity gradients between the steel and the sodium, which are produced by different initial carbon contents in the steel and/or the carbon content of the sodium. In principle, the data used to calculate the decarburization rate constant can be normalized with respect to these factors, from a knowledge of the carbon concentrationcarbon activity relationship shown in Fig. 2 and the carbon activity in sodium. However, at temperatures $\leqslant 750 \mathrm{~K}$, the initial heat treatment of Fe-2 $\frac{3}{4} \mathrm{Cr}-1 \mathrm{Mo}$ (e.g., normalized and tempered, annealed, or isothermally annealed) influences the carbide structure and consequently the decarburization kinetics. Also, the carbon concentration in sodium in many investigations was not determined experimentally. 


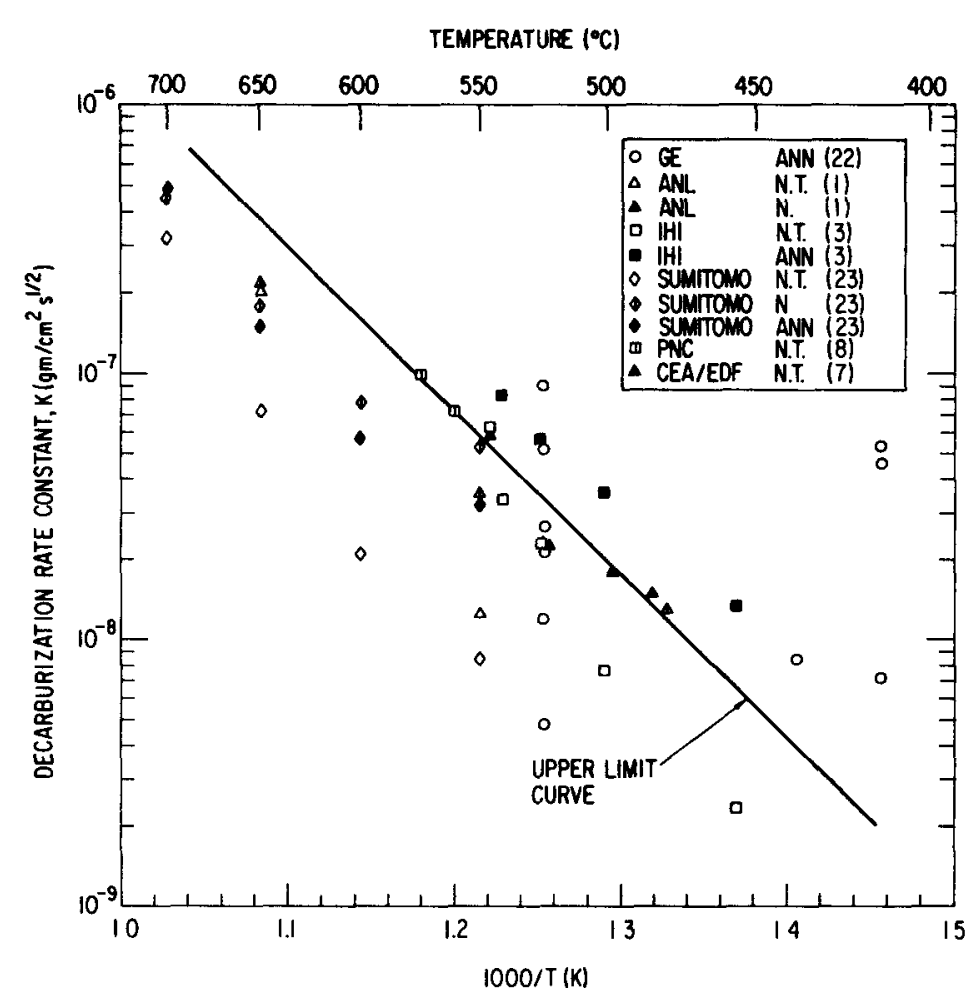

Fig. 4

Temperature Dependence of Decarburization Rate Constants for $\mathrm{Fe}-2 \frac{1}{4} \mathrm{Cr}-1 \mathrm{Mo}$ Stee1 in Sodium. ANL Neg. No. 306-79-488.
The influence of heat treatment on the decarburization rate constant can be seen in Fig. 4. The values for the normalized and tempered material lie well below the upper limit curve, whereas the rate constants for the normalized or annealed material lie above or along the upper limit curve. Differences observed in the rates of decarburization between normalized and normalizedtempered material result from variations in the carbon activity in steel that occur due to the different microstructures and carbide phases which evolve during the initial heat treatment. When exposed to high-temperature sodium, the material undergoes microstructural changes due to thermal aging and interstitial element transfer. The initial structure and subsequent changes in the microstructure play in important role in the kinetics of decarburization.

The carbide phases present in normalized steel are primarily $\mathrm{M}_{7} \mathrm{C}_{3}$ and $\mathrm{M}_{23} \mathrm{C}_{6}$ with a small amount of $\mathrm{M}_{2} \mathrm{C}$ carbide whereas the normalized and tempered steel contains mostly $\mathrm{M}_{23} \mathrm{C}_{6}$ and $\mathrm{M}_{6} \mathrm{C}$ carbides. Thermal aging of the material at temperatures between 820 and $970 \mathrm{~K}$ leads to the formation of $\mathrm{M}_{6} \mathrm{C}$ carbide according to the sequence

\section{Bainite}

$\varepsilon$ carbide

$$
+\quad \rightarrow \text { cementite } \rightarrow
$$

cementite

Ferrite

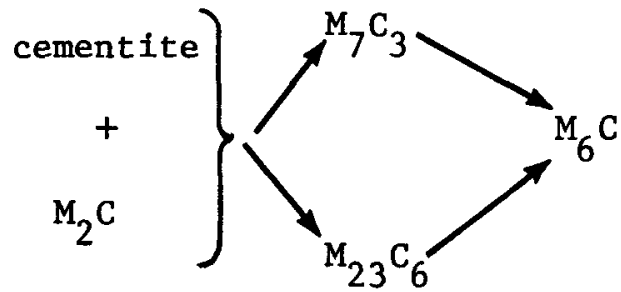

$$
M_{2} C \rightarrow M_{6} C
$$


When the $\mathrm{Fe}-2 \frac{3}{4} \mathrm{Cr}-1 \mathrm{Mo}$ steel is exposed to sodium at high temperatures, carbon loss from the material accelerates the formation of $\mathrm{M}_{6} \mathrm{C}$. The $\mathrm{M}_{6} \mathrm{C}$ carbides are considered to be resistant to decomposition because of their relatively stable thermodynamic state in contrast to $\mathrm{M}_{23} \mathrm{C}_{6}$ and $\mathrm{M}_{7} \mathrm{C}_{3}$. Consequently, the decarburization rate of normalized steel would be higher than that of normalized and tempered steel. The normalized steel will decarburize to a certain carbon level at each temperature corresponding to a stable carbide structure. Any additional decarburization will be slow because the decarburization rate will be controlled by the dissolution rate of the carbide phases in the ferrite matrix. A decrease in the decarburization rate constant with time has been observed in isothermally annealed $\mathrm{Fe}-2 \frac{7}{4} \mathrm{Cr}-1 \mathrm{Mo}$ steel after prolonged sodium exposure. 22

The studies on the carbon-transfer behavior of $\mathrm{Fe}-9 \mathrm{Cr}-\mathrm{Mo}$ steels in sodium show that these steels can either carburize or decarburize depending on the carbon activity in sodium. ${ }^{9}, 10,21$ The carburization or decarburization rate constant can be obtained from the change in carbon concentration per unit surface area of material exposed to sodium using Eq. 3. The temperature dependence of the rate constant is shown in Fig. 5. The results show that in the temperature range from 770 to $920 \mathrm{~K}$ the carburization/ decarburization rate constant is $22 \times 10^{-8} \mathrm{~g} / \mathrm{cm}^{2} \mathrm{~s}^{1 / 2}$. Similar values for the rate constant were reported by Menken et al. ${ }^{10}$ at 773 and $873 \mathrm{~K}$.

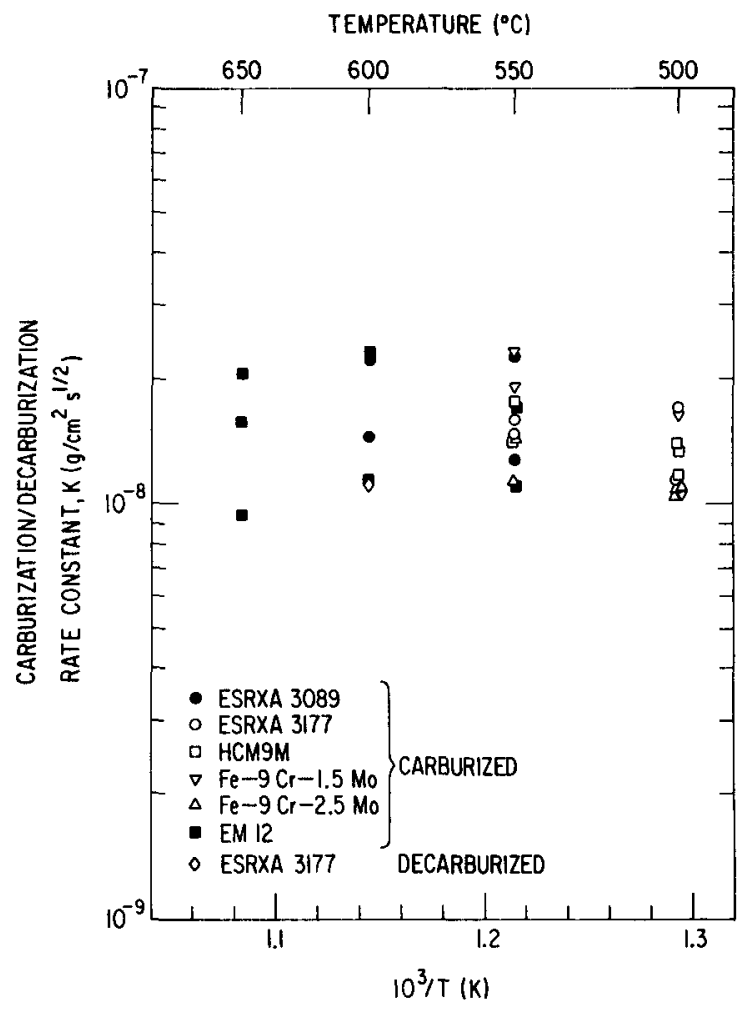

Fig. 5

Temperature Dependence of Carburization/Decarburization Rate Constants for Fe-9Cr-Mo Steels in Sodium (Ref. 21). ANL Neg. No. 306-78-910.

The carburization/decarburization behavior of highermchromium ferritic steels is also very sensitive to the microstructure obtained during the Initial heat treatment. Studies on the stability of carbide phases in various chromiummolybdenum steels ${ }^{24-26}$ show that the most stable 
carbides in Fen9Cr-l to 2Mo steels are $\mathrm{M}_{23} \mathrm{C}_{6}$ and $\mathrm{M}_{6} \mathrm{C}$. Analyses of carbides extracted from several Fe-9Cr-Mo steels revealed that the $M_{2} X$ phase (a metal carbide/nitride phase), which forms during the initial heat treatment, was present in the microstructure. This phase is metastable at high temperatures and eventually transforms to $\mathrm{M}_{23} \mathrm{C}_{6}$ or $\mathrm{M}_{6} \mathrm{C}$ carbides with time. Steels containing $\mathrm{M}_{2} \mathrm{X}$ phase in the initial microstructure are prone to decarburization when exposed to sodium with low carbon activity. ${ }^{1}$

The transport of nitrogen into and out of ferritic steels in a sodium environment can occur independent of carbon migration. 8,9 The extent of nitrogen transfer in $\mathrm{Fe}-2 \frac{1}{4} \mathrm{Cr}-1 \mathrm{Mo}$ and $\mathrm{Fe}-9 \mathrm{Cr}-\mathrm{Mo}$ steels after exposure to sodium is shown in Figs. 6 and 7, respectively. The results for $\mathrm{Fe}-9 \mathrm{Cr}-\mathrm{Mo}$ steels show that nitrogen loss from these steels is negligible at temperatures below $820 \mathrm{~K}$. At higher temperatures, nitrogen loss increases with an increase in either the sodium-exposure temperature or time.

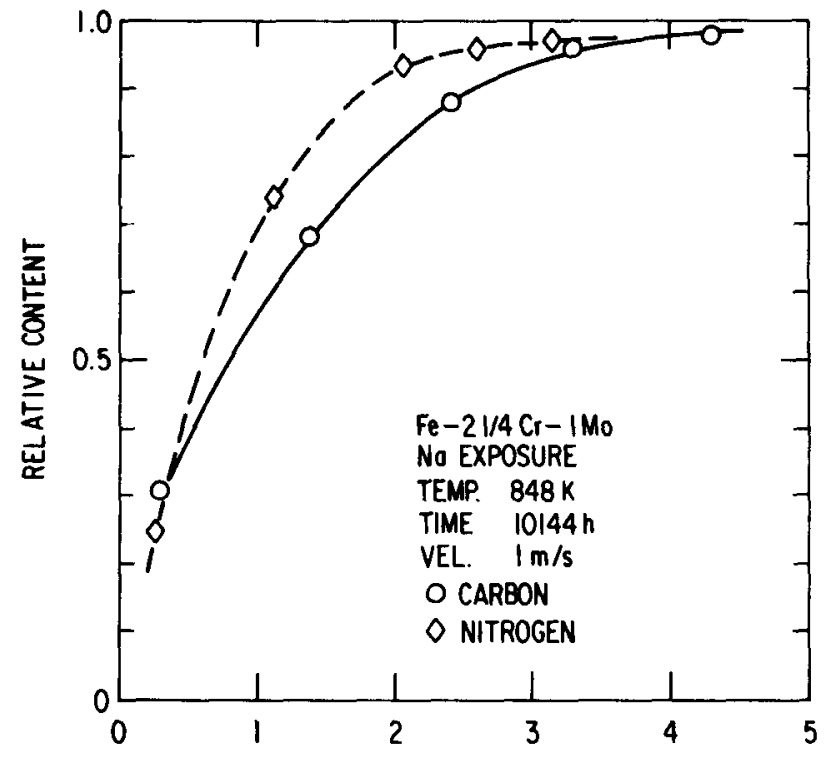

Fig. 6

Change in Carbon and $\mathrm{Ni}-$ trogen Concentrations in Normalized and Tempered $\mathrm{Fe}-2 \frac{1}{4} \mathrm{Cr}-1 \mathrm{Mo}$ Steel after Exposure to Flowing Sodium (Ref. 8). ANL Neg. No. 306-79-489.

DISTANCE FROM SURFACE EXPOSED TO SODIUM $(\mathrm{mm})$

\section{Mechanical Properties}

The loss of carbon from $\mathrm{Fe}-2 \frac{1}{4} \mathrm{Cr}-1$ Mo steel in a sodium environment leads to a reduction in mechanical strength. For components with intermediate section thicknesses (e.g., pipe), the decrease in strength is proportional to the depth of the decarburized layer. Maximum reduction in strength will occur in thin sections, namely, superheater and evaporator tubing. Therefore, for design of components with thin and intermediate section thicknesses, it is essential to establish long-term environmental effects and modify the allowable design stresses to ensure satisfactory performance of components over the expected service life.

Ideally, the effect of sodium environment on the mechanical behavior of structural materials should be evaluated from mechanical property data on materfal with specific depths of decarburized or carburized layer, 


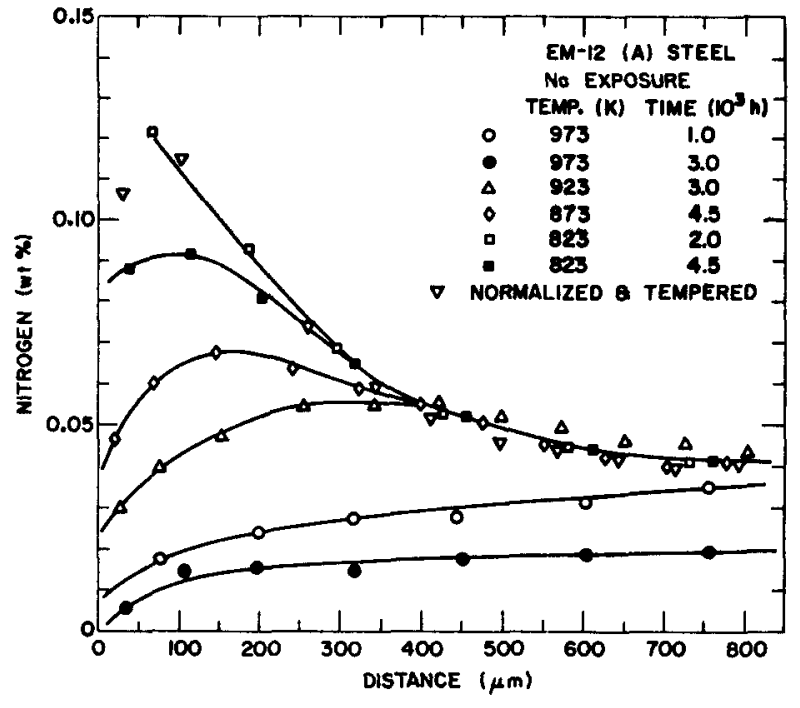

(a)

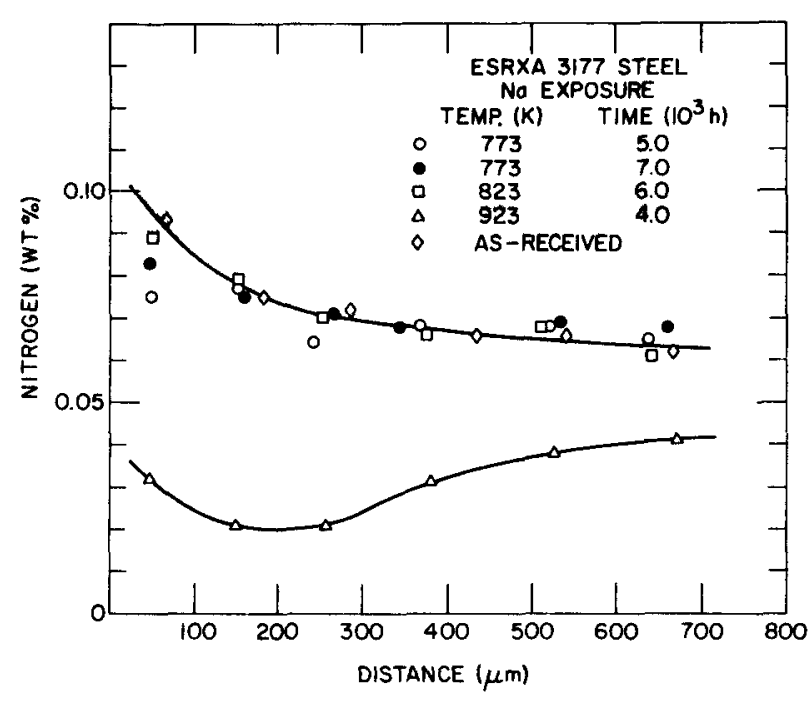

(b)

Fig. 7. Nitrogen Concentration-Distance Profiles in Fe-9Cr-Mo Steels after Exposure to Flowing Sodium at Temperatures between 773 and $973 \mathrm{~K}$ (Ref. 8, 21). ANL Neg. Nos. 306-78-915 Rev. 1 and 306-78-914 Rev, 1 .

which were estab1ished under known conditions, e.g., time, temperature and sodium purity. However, the current assessment of the change in mechanical behavior of $\mathrm{Fe}-2 \frac{1}{4} \mathrm{Cr}-1 \mathrm{Mo}$ steel due to decarburization in a sodium environment is primarily based on the mechanical-property data obtained from steels with low initial bulk carbon contents. ${ }^{5}, 27-30$ These data are in a good agreement with results obtained from specimens which were decarburized in sodium to different bulk carbon contents.31-35 The tensile and yield strengths of $\mathrm{Fe}-2 \frac{3}{4} \mathrm{Cr}-1$ Mo steel with different carbon contents is shown in Fig. 8. The results indicate that the strength of steels with $>0.03$ wt \% carbon is generally above the lower-limit curve recommended by the NSMH. Steels with $\hat{\sigma}_{0.01}$ wt \% carbon exhibit poor tensile and yield strengths.

The tensile and yield strengths of specimens which were exposed to elevated-temperature sodium prior to testing are given in Fig. 9. Decarburization of the specimens causes a reduction in mechanical strength. Recent studies of the influence of thermal aging on the mechanical properties of $\mathrm{Fe}-2 \frac{1}{4} \mathrm{Cr}-1 \mathrm{Mo}$ steel show that age softening is a dominant characteristic of this steel. ${ }^{36}$ Consequently, to establish the effect of a sodium environment on the mechanical properties it is important to evaluate the influence of thermal aging as well as decarburization. Figure 10 shows the change in mechanical strength of decarburized $\mathrm{Fe}-2 \frac{7}{4} \mathrm{Cr}-1 \mathrm{Mo}$ steel as a function of bulk carbon content. The control data shown in this figure refer to specimens that were thermally aged in an inert atmosphere for identical time and temperature conditions. Decarburization progressively reduces the tensile and yield strengths of the steel. The data can be used to estimate the time-dependent reduction in tensile strength due to decarburization. Based on the decarburization kinetics shown in Fig. 4, 
TEMPERATURE $\left({ }^{\circ} \mathrm{C}\right)$

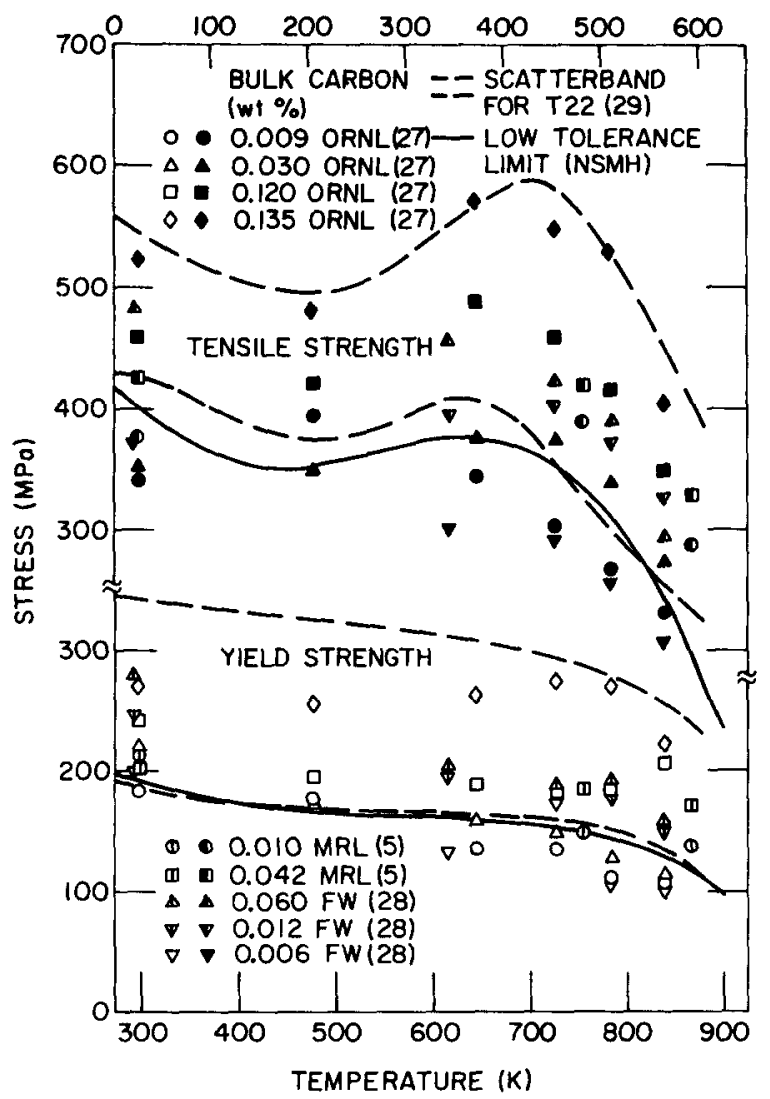

Fig. 8

Yield and Tensile Strengths for $\mathrm{Fe}-2 \frac{1}{4} \mathrm{Cr}-1 \mathrm{Mo}$ Steels Containing Different Bulk Carbon Concentrations. ANL Neg. No. 306-79-490.
TEMPERATURE $\left({ }^{\circ} \mathrm{C}\right)$

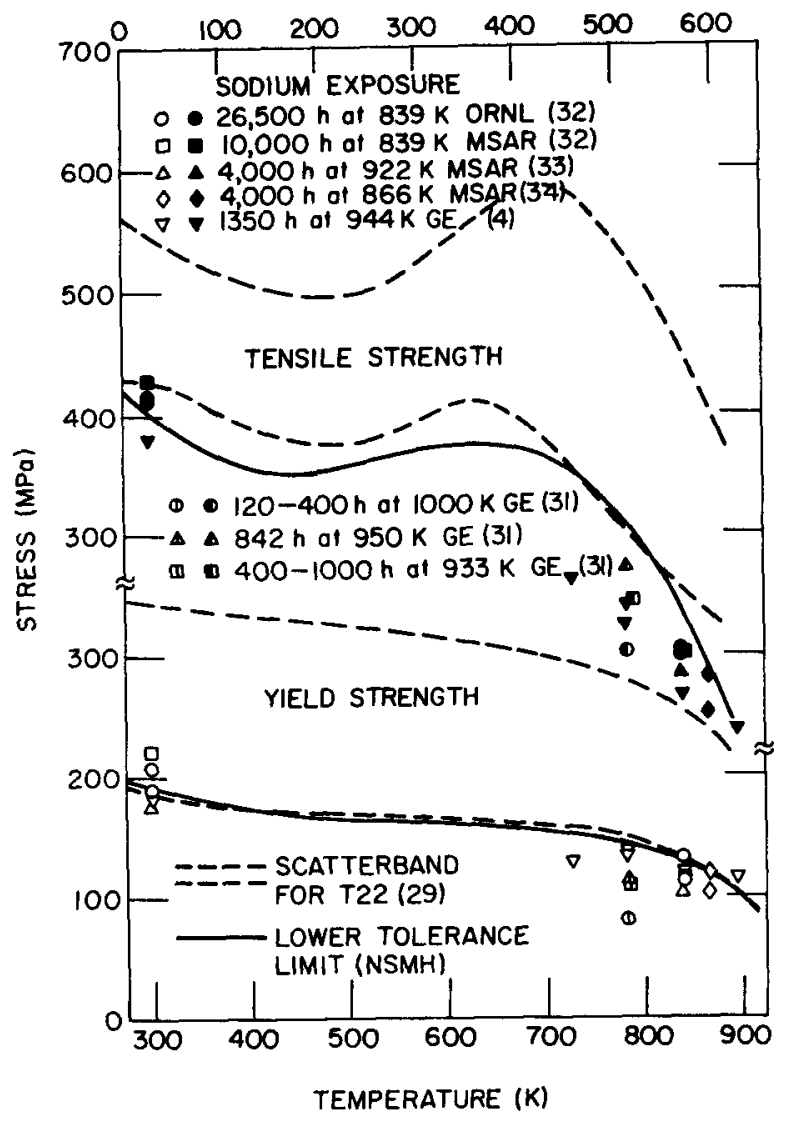

Fig. 9

Yield and Tensile Strengths for Fe- $2 \frac{1}{4} \mathrm{Cr}-1 \mathrm{Mo}$ Steels after Decarburization in Sodium. ANL Neg. No. 306-79-491.

the total carbon loss for superheater tubing ( $\sim 3$ thick) during a design life of $10^{5} \mathrm{~h}$ at $783 \mathrm{~K}$ is approximately $0.025 \mathrm{wt} \%$. This represents a strength reduction of $\sim 10 \%$.

The Influence of sodium environment on the creepnrupture properties of $\mathrm{Fe}-2 \frac{3}{4} \mathrm{Cr}-1 \mathrm{Mo}$ steel is due main1y to decarburization of the material. At temperatures below $870 \mathrm{~K}$ the creep-rupture strength of $\mathrm{Fe}-2 \frac{3}{4} \mathrm{Cr}-1 \mathrm{Mo}$ steel in alr and sodium environments is essentially the same. ${ }^{35}$ Consequently, the sodium effect on creep-rupture properties of $\mathrm{Fem} 2 \frac{7}{4} \mathrm{Cr}-1$ Mo steel can also be assessed from data on steels with low inttial carbon contents. Figure 11 shows a parametric plot of stress-rupture-strength data for $\mathrm{Fe}-2 \frac{1}{4} \mathrm{Cr}-1 \mathrm{Mo}$ steel with different bulk carbon contents. The creeprrupture strength for $10^{3}$ and $10^{4} \mathrm{~h}$ at temperatures between 755 and $866 \mathrm{~K}$ is shown as a function of bulk carbon content in Fig. 12. These curves can be used to determine the reduction in the creepmrupture strength due to carbon loss in a sodium environment, as shown in Fig. 13. The rupture strengths of specimens that 

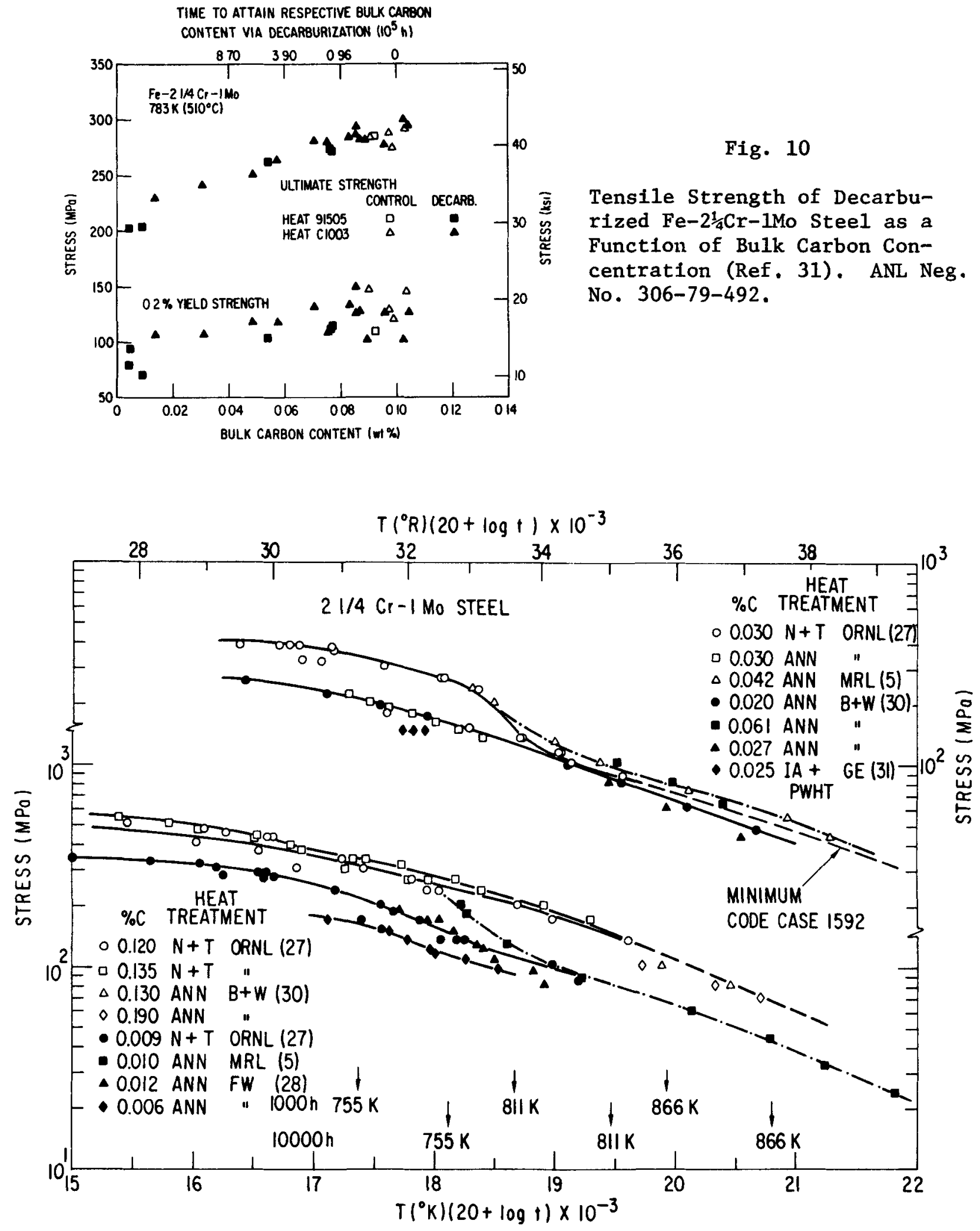

Fig. 11. Larson-Miller Parameter Diagram for $\mathrm{Fe}-2 \frac{1}{4} \mathrm{Cr}-1$ Mo Steels Containing Different Bulk Carbon Concentrations. ANL Neg. No. 306-79-493. 


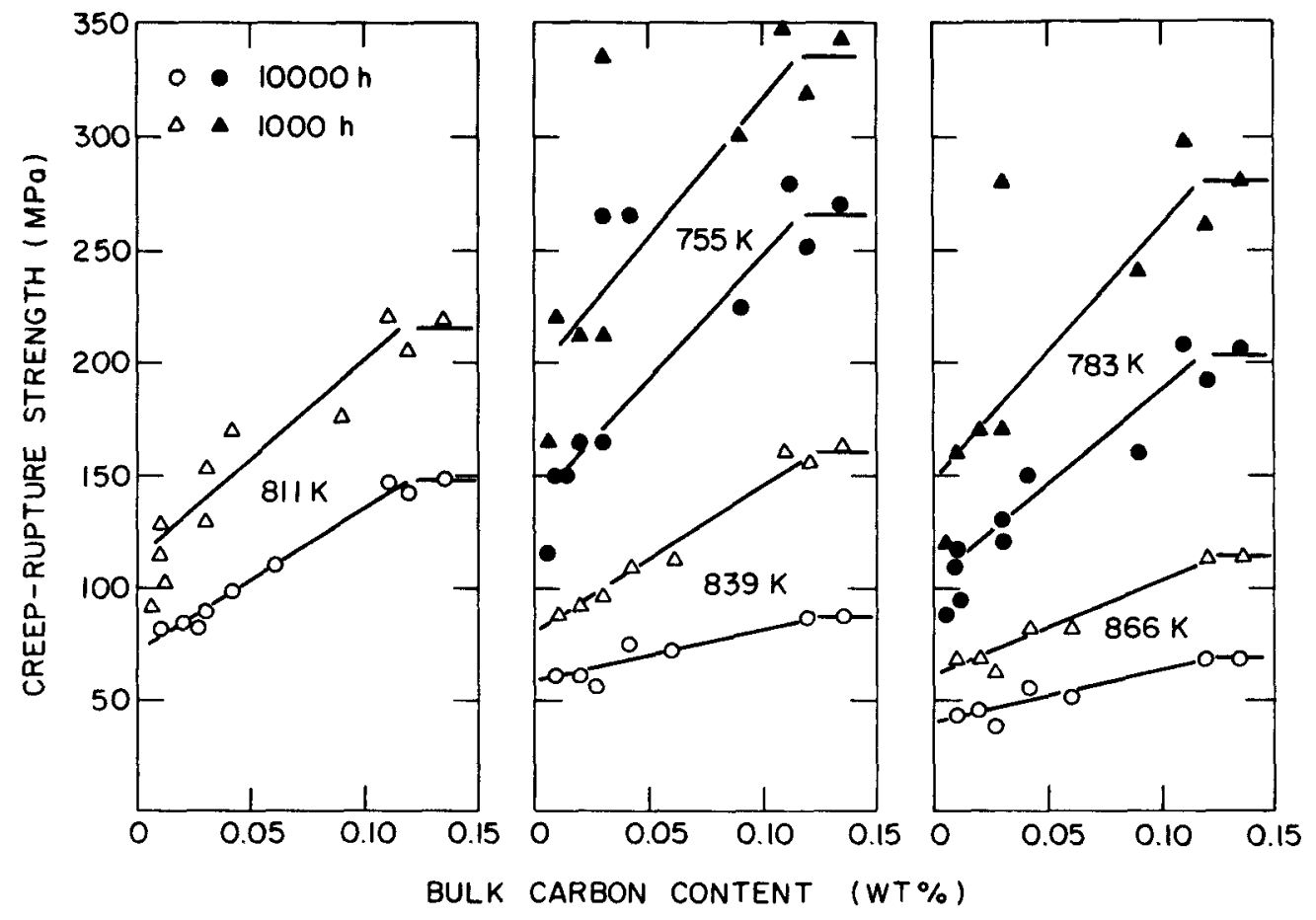

Fig. 12. Creep-rupture Strength for $\mathrm{Fe}-2 \frac{1}{4} \mathrm{Cr}-1 \mathrm{Mo}$ Steel as a Function of Bulk Carbon Concentration. ANL Neg. No. 306-79-494.

Fig. 13

Relation between Loss of Carbon due to Decarburization in Sodium and Creep-rupture Strength Ratio for $\mathrm{Fe}-2 \frac{1}{4} \mathrm{Cr}-1$ Mo Steel. ANL Neg. No. 306-79-495.

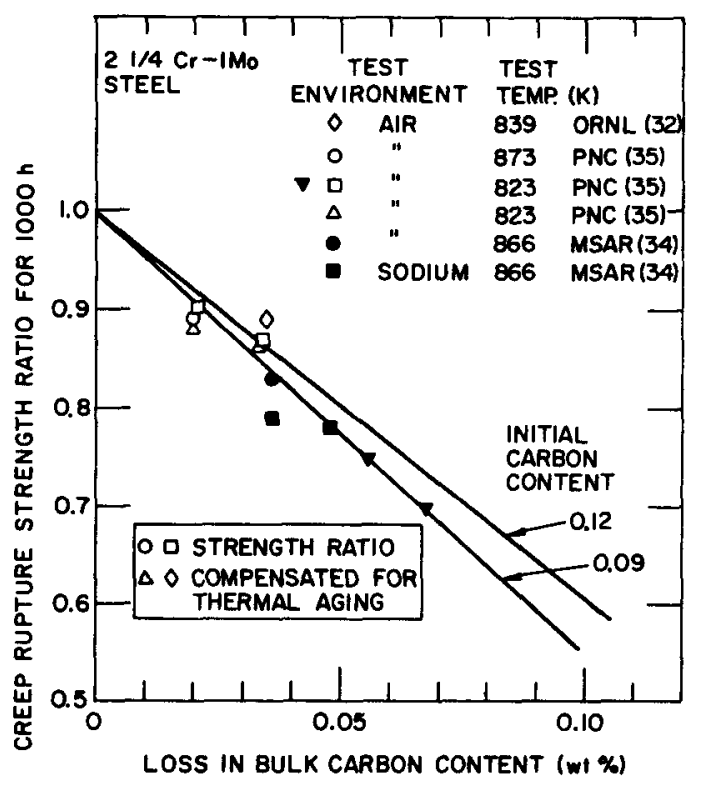


were decarburized in a sodium environment to different bulk carbon contents are also plotted in Fig. 13 and show a good agreement with the computed curves. This analysis indicates that the reduction in creep-rupture strength for $\mathrm{Fe}-2 \frac{1}{4} \mathrm{Cr}-1 \mathrm{Mo}$ steel superheater tubing during a service life of $10^{5} \mathrm{~h}$ in sodium at $783 \mathrm{~K}$ will be $\sim 10 \%$. The loss in bulk carbon content and the change in creep-rupture strength at different temperatures is plotted in Fig. 14 as a function of section or wall thickness of a component. The results show that the $10^{5}-\mathrm{h}$ creep-rupture strength ratio for material with wall thicknesses $>3 \mathrm{~mm}$ is $>0.9$.

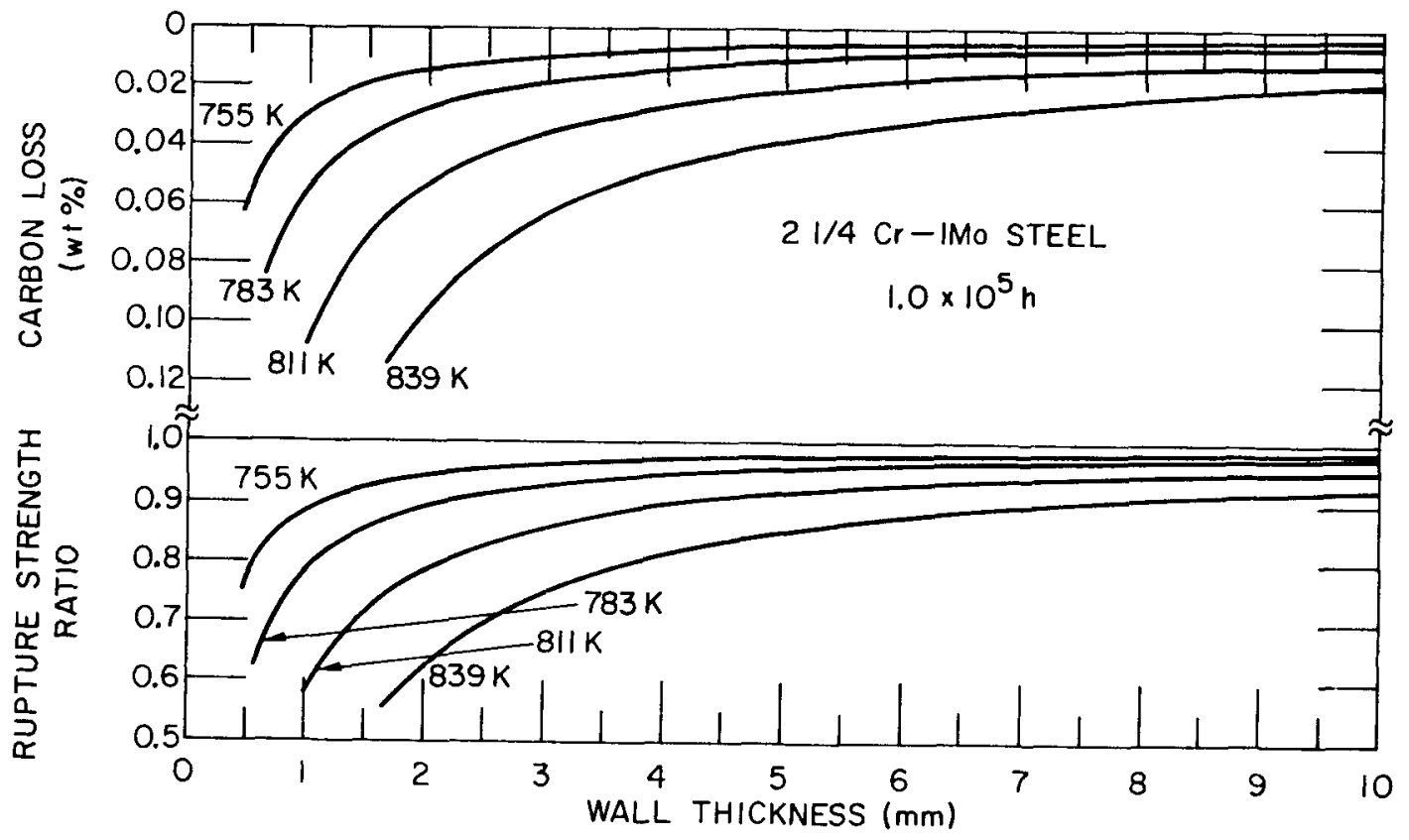

Fig. 14. Change in Carbon Concentration and Creep-rupture Strength for $\mathrm{Fe}-2 \frac{1}{4} \mathrm{Cr}-1 \mathrm{Mo}$ Steel as a Function of Wa11 Thickness. ANL Neg. No. 306-79-496.

In contrast to the tensile and creep properties, where the variation in mechanical strength is primarily due to decarburization rather than the sodium environment per se, the fatigue life of $\mathrm{Fe}-2 \frac{1}{4} \mathrm{Cr}-1 \mathrm{Mo}$ steel tested in sodium is greater by a factor of 3 to 10 than when tested in air. 34,37-39 The absence of surface oxidation in a sodium environment increases the fatigue life of the material. In oxidizing environments such as air or steam, the oxide scale which forms on the surface of the test specimen can influence the crack-initiation process. However, the partial pressure of oxygen in a liquid-sodium environment is much lower than that of other test environments and, therefore, surface oxidation effects are less likely to influence fatigue life in liquid sodium.

The influence of sodium environment on the fatigue life of $\mathrm{Fe}-2 \frac{3}{4} \mathrm{Cr}-$ 1 Mo steel at temperatures of 755 and $811 \mathrm{~K}$ is shown in Fig. 15. Although the fatigue life of as-received material is greater in sodium than in air environment, the fatigue life of thermally aged or sodium-exposed specimens is $40 \%$ lower compared to the as-received material. 37,38 


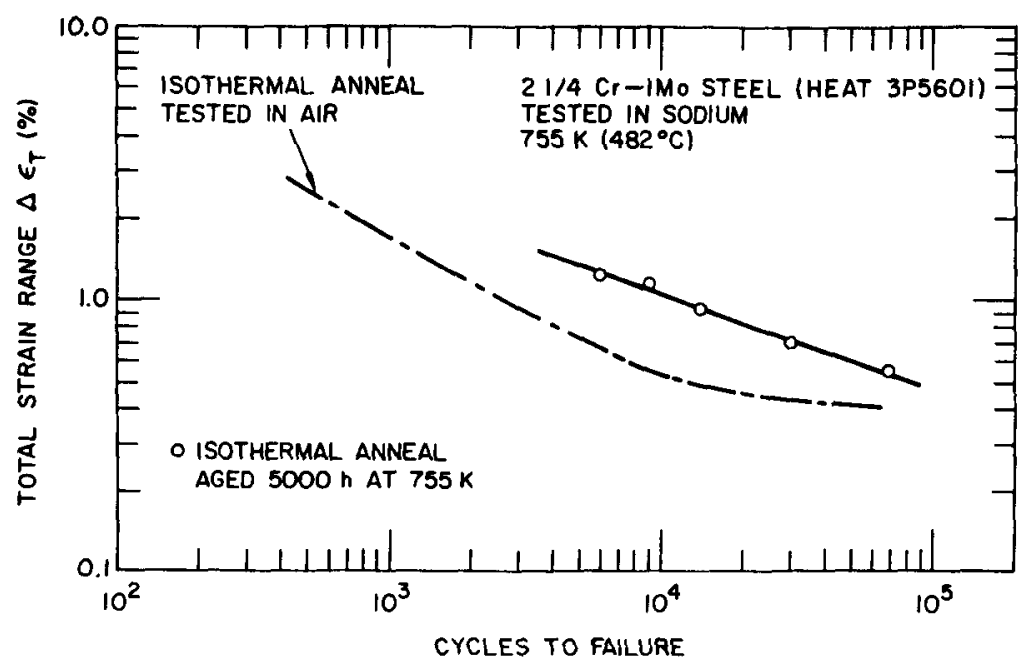

(a)

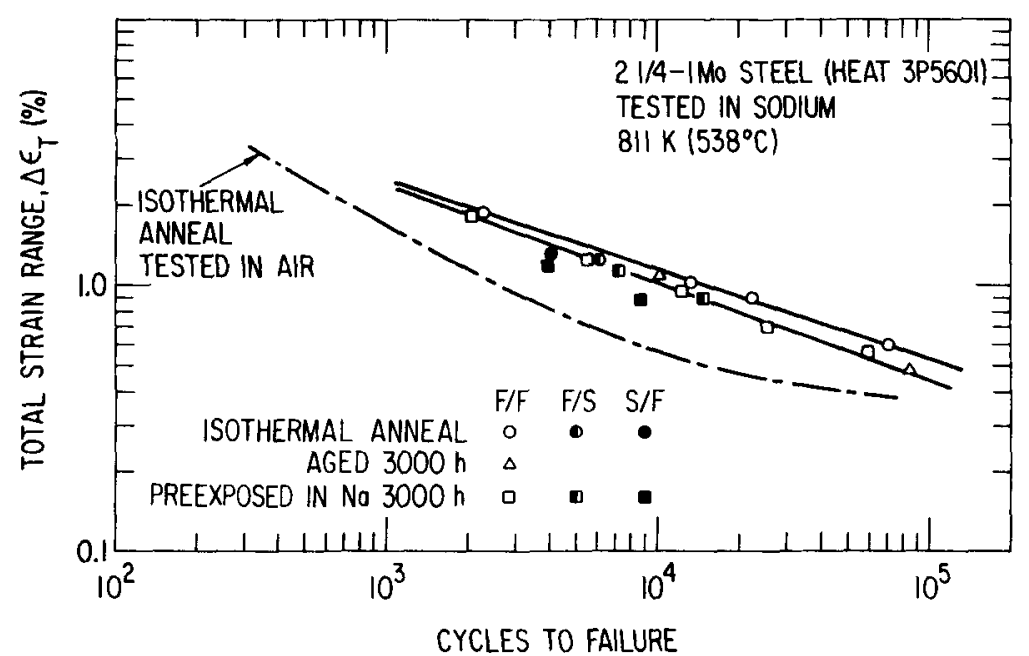

(b)

Fig. 15. Fatigue-1ife Curves for Fe-2 $\frac{1}{4} \mathrm{Cr}-1$ Mo Steel

Tested in Sodium at (a) $755 \mathrm{~K}$ and (b) $811 \mathrm{~K}$. Strain rates $\mathrm{F}$ and $\mathrm{S}$ are $4 \times 10^{-3}$ and $4 \times 10^{-5} \mathrm{~s}^{-1}$, respectively (Refs, 37,38 ). ANL Neg. Nos. 306-79-497 and 306-79-498.

The creep-fatigue interaction for $\mathrm{Fe}-2 \frac{1}{4} \mathrm{Cr}-1 \mathrm{Mo}$ steel has also been investigated ${ }^{37}$ in a sodium environment using a sawtooth waveform in which strain rates during the tensile and compressive half of the fatigue cycle differ by a factor of 100 . Initial results from these tests are shown in Fig. 15. The fatigue life of isothermally annealed and sodium-exposed specimens tested under fast-slow conditions (similar to compressive holdtime tests) is approximately the same as that for specimens tested under continuous cycling, whereas the fatigue life under slow-fast conditions (similar to tensile hold-time tests) is a factor of $\sim 2$ lower. This behavior for $\mathrm{Fe}-2 \frac{1}{4} \mathrm{Cr}-1 \mathrm{Mo}$ steel in a sodium environment is opposite to that in air, 
where compressive hold time was found to be more damaging than tensile hold time at low strain ranges $(<1 \%) .40,41$

Data on the effect of sodium environment on the mechanical properties of $\mathrm{Fe}-9 \mathrm{Cr}-\mathrm{Mo}$ steels are sparse. The tensile and creep-rupture strengths for various $\mathrm{Fe}-9 \mathrm{Cr}-\mathrm{Mo}$ steels tested in air are shown in Figs. 16 and 17, respectively. ${ }^{42,46}$ Most of the results were obtained on normalized and tempered $\mathrm{Fe}-9 \mathrm{Cr}-\mathrm{Mo}$ steels; however, the lower-limit tensile-strength curve for $\mathrm{Fe}-2 \frac{3}{4} \mathrm{Cr}-1 \mathrm{Mo}$ steel (NSMH) and the DS58 minimum creep-strength curve for Fe-9Cr-Mo steel are for annealed material. In Section II.B. it was shown that under typical temperature and sodium-purity conditions, the Fe-9Cr-Mo steels tend to carburize. Consequently, the effect of sodium on the mechanical properties of $\mathrm{Fe}-9 \mathrm{Cr}-\mathrm{Mo}$ steels should be similar to that of the Types 304 and 316 stainless steel. In general, moderate carburization improves the tensile and creep-rupture strengths of austenitic stainless steels. Limited results indicate that sodium environment has virtually no effect on either the tensile or creep-rupture strengths of $\mathrm{Fe}-9 \mathrm{Cr}-\mathrm{Mo}$ steels. $14,47,48$ Carburization of $\mathrm{Fe}-9 \mathrm{Cr}-\mathrm{Mo}$ steel in sodium increases creep endurance in short-term tests but causes a significant decrease in rupture ductility. ${ }^{49}$ From this limited evidence, it can be concluded that the sodium environment will have no significant effect on the mechanical strength of $\mathrm{Fe}-9 \mathrm{Cr}-\mathrm{Mo}$ steels at temperatures below $820 \mathrm{~K}$.

TEMPERATURE $\left({ }^{\circ} \mathrm{C}\right)$

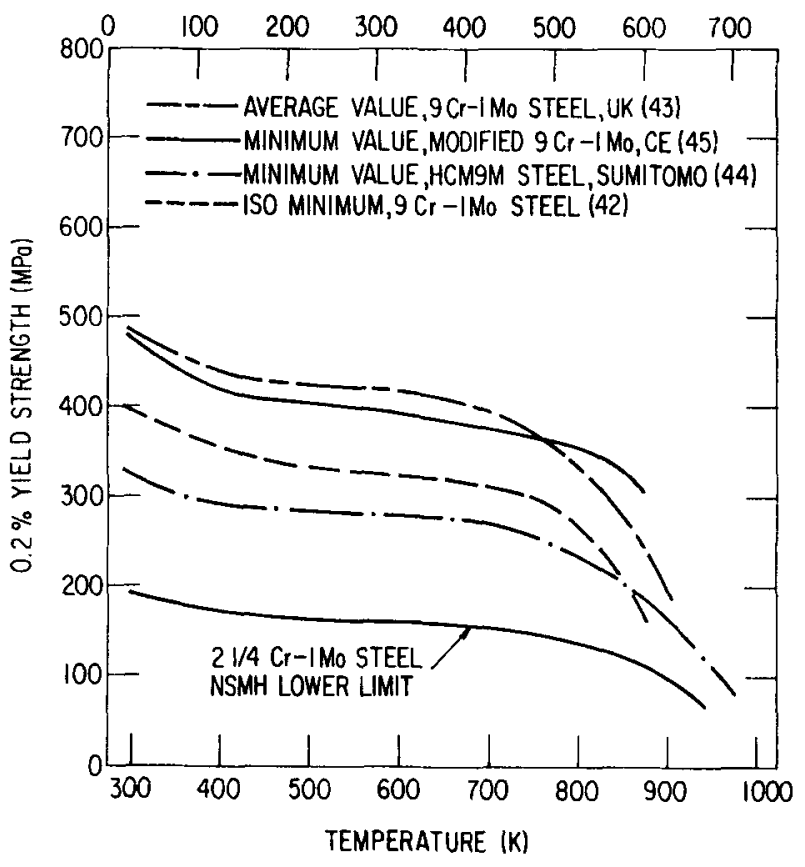

(a)
TEMPERATURE ( $\left.{ }^{\circ} \mathrm{C}\right)$

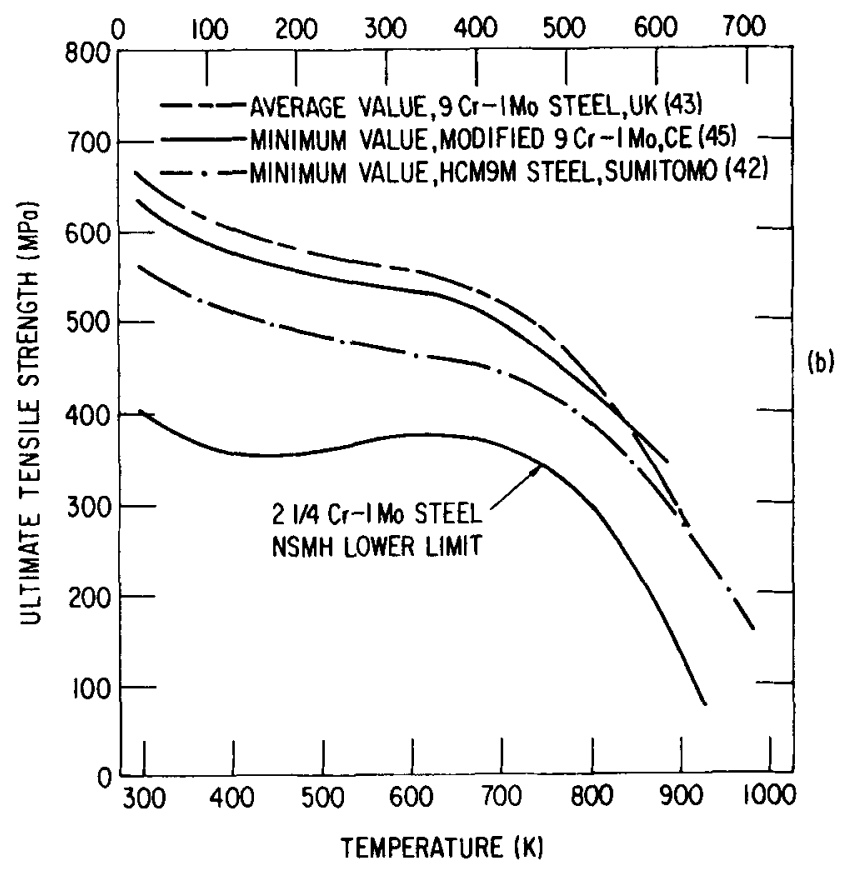

(b)

Fig. 16. Effect of Temperature on the (a) Yield and (b) Ultimate Strengths of Fe-9Cr-Mo Steels. ANL Neg. Nos. 306-79-499 and 306-79-500. 


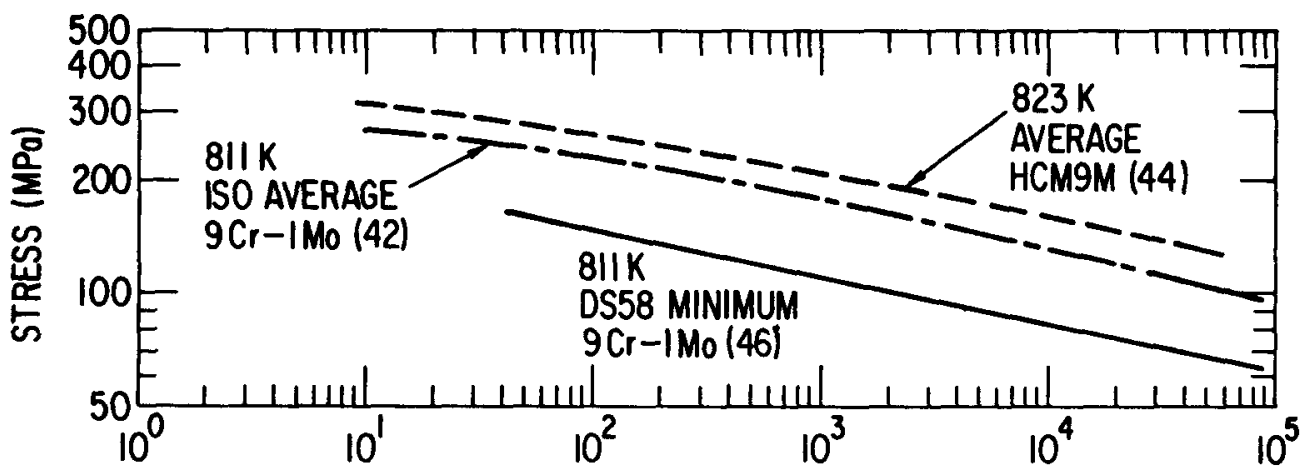

TIME TO RUPTURE (h)

(o)

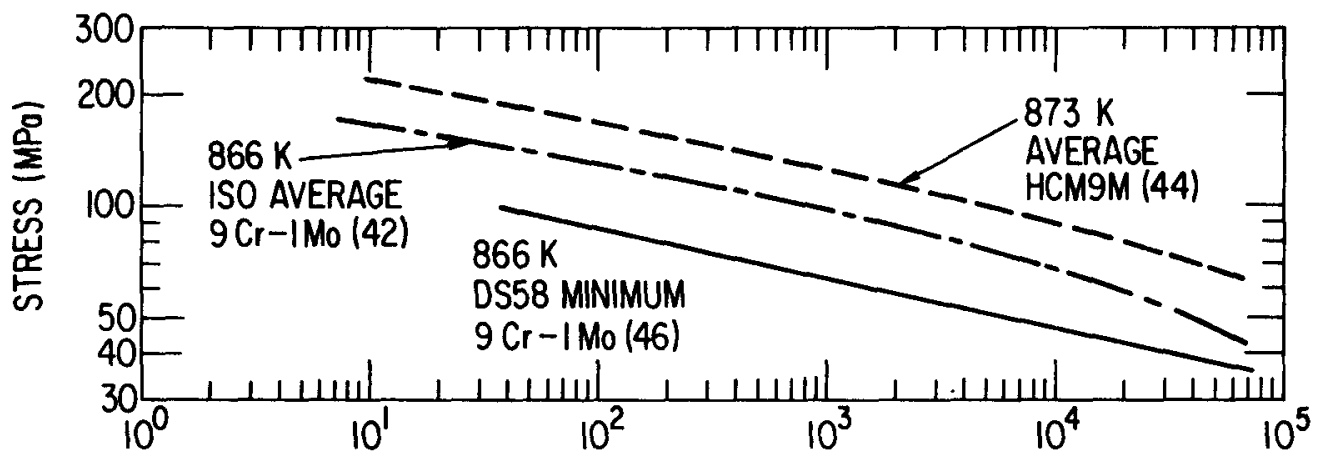

TIME TO RUPTURE (h)

(b)

Fig. 17. Stress-rupture Curves for Fe-9Cr-Mo Steels at (a) $811 \mathrm{~K}$ and (b) $866 \mathrm{~K}$. ANL Neg. Nos. 306-79-501 and 306-79-502.

The fatigue life of ferritic steels, in general, is better in sodium than in air. Although the fatigue behavior of $\mathrm{Fe}-9 \mathrm{Cr}-\mathrm{Mo}$ steel in sodium has not been investigated, the fatigue life in a helium environment is $10 \%$ higher than that in air (Fig. 18). ${ }^{2}$ Data on the effect of sodium environment on the mechanical behavior of $\mathrm{Fe}-9 \mathrm{Cr}-\mathrm{Mo}$ steels are needed to establish the performance limits for components fabricated from this material.

\section{BEHAVIOR OF AUSTENITIC STAINLESS STEELS IN SODIUM}

Austenitic stainless steels, e.g., Type 304, 316, and 321, have been selected for core components, piping, and superheater and reheater units in LMFBRs on the basis of adequate corrosion resistance and higher allowable design stresses than ferritic steels at temperatures above $770 \mathrm{~K}$. The susceptibility of austenitic steels to stress-corrosion cracking in the presence of chlorides in the steam generator and intergranular cracking in a caustic environment, which could result from water leaks, is an important consideration in the selection of the material for sodium-to-water 


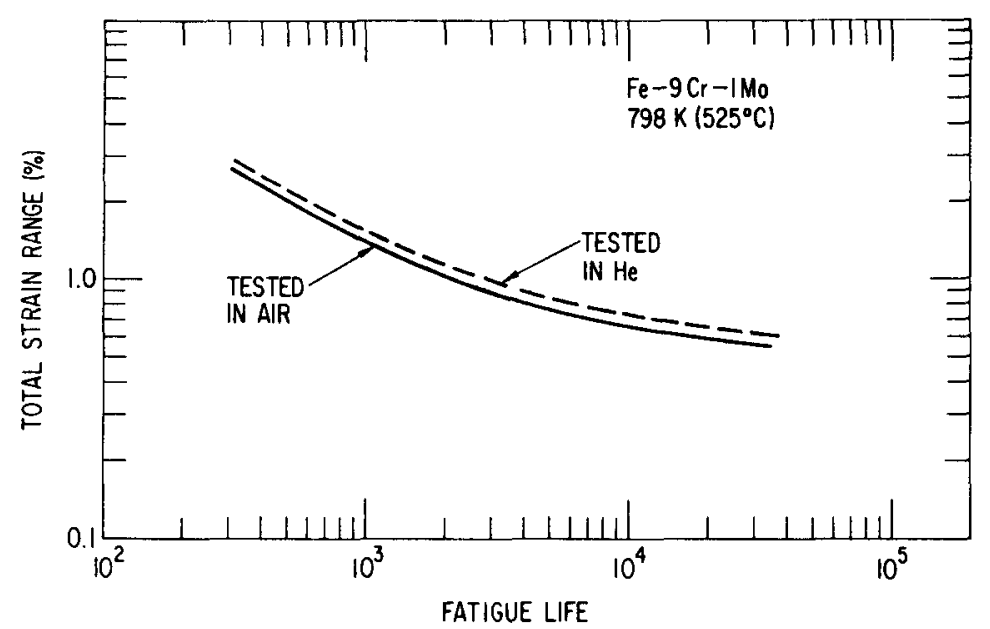

Fig. 18

Fatigue-life Curves for Fe-9Cr-1Mo Steel Tested in Air and Helium Environments. Curves based upon data reported in Ref. 50. ANL Neg. No. 306-79-503.

heat exchangers. Potentlal problems can be minimized by good design and fabrication practice, adequate treatment of the feedwater, and by modular concept for the superheater units.

\section{A. Corrosion}

The corrosion behavior of austenitic stainless steels in a liquidsodium environment is well documented over the temperature range from 720 to $1030 \mathrm{~K}$, oxygen content of 1 to $30 \mathrm{ppm}$ in the sodium, and sodium velocities between 0.1 and $12 \mathrm{~m} / \mathrm{s} .12,13,17,51-58$ In general, the corrosion rate for austenitic stainless steels reaches a steady-state value after an initial period of rapid metal loss. The steady-state corrosion rate increases exponentially with temperature and linearly with oxygen content and sodium velocity up to $\sim 3 \mathrm{~m} / \mathrm{s}$. The corrosion rate becomes independent of velocity at the higher values. Corrosion results from investigations in the UK, Netherlands, France, Japan, and the USA were used to obtain the corrosionrate correlations for Type 316 stainless stee $1^{57}$ shown in Fig. 19. These data refer to steady-state corrosion rates determined at locations of maximum corrosion, i.e., maximum upstream position. The downstream or positional effect, metallurgical condition of the material (e.g., annealed or cold-worked), and minor variations in the nickel, chromium, niobium, or titanium contents of the stainless steels have relatively 1ittle influence on the corrosion rates in comparison with the temperature, oxygen content and velocity of the sodium.

The most notable structural change in stainless steels exposed to liquid sodium is the formation of a 10 - to $20-\mu \mathrm{m}$-thick ferrite layer at the surface due to preferential leaching of chromium and nickel from the steel. The ferrite-layer thickness as well as the corrosion rate attains a steady-state value after an initial corrosion period, i.e., the flux of chromium and nickel across the austenite/ferrite interface is approximately equivalent to that across the metal/sodium interface at an early stage of the process ( $\sim 500$ to $1000 \mathrm{~h}$ ). 


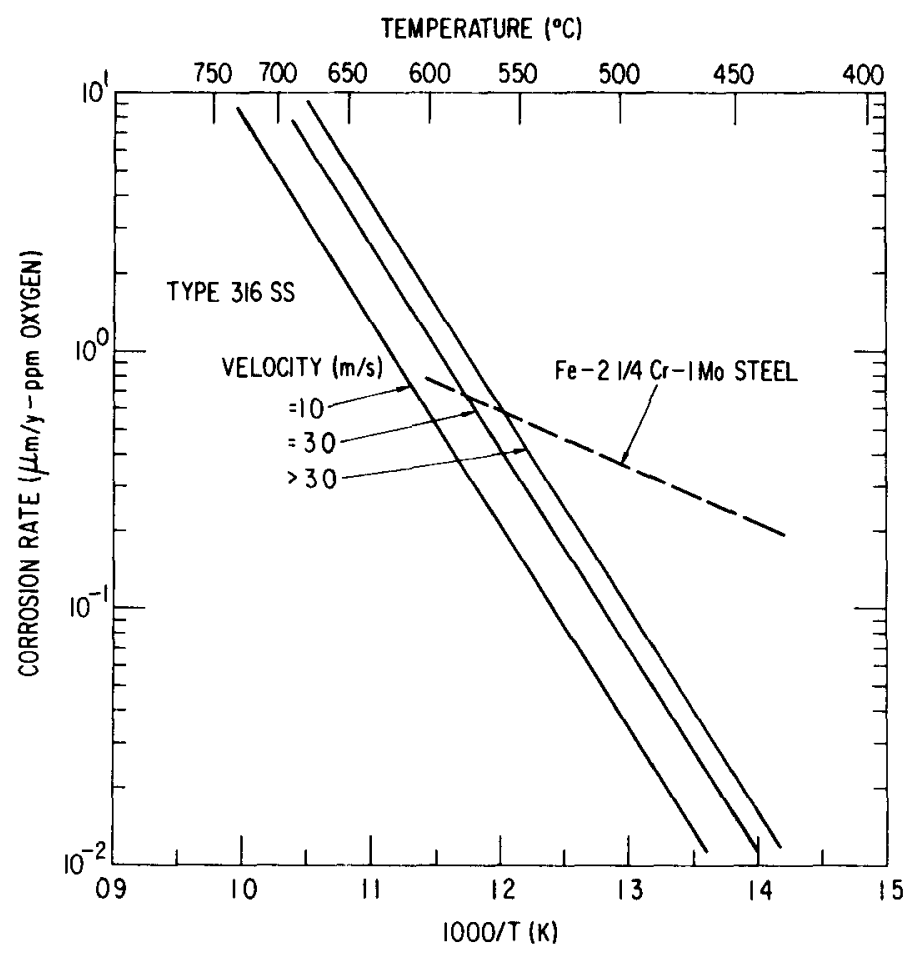

Fig. 19

Effect of Temperature on the Corrosion Rate of Type 316 Stainless Steel in Flowing Sodium. ANL Neg. No. 306-79-504.

The corrosion rates shown in Fig. 19 do not incorporate the influence of high heat flux. A recent corrosion study performed under high axia1-temperature gradient (dT/dL) conditions (corresponding to a heat flux of $\left.\sim 1600 \mathrm{~kW} / \mathrm{m}^{2}\right)^{55}$ has shown an enhancement over the predicted corrosion rates by a factor of 1.5 to 2.0 . Consideration of probable mechanisms for the corrosion process suggests that under high axial-temperature gradients, the temperature of sodium in the vicinity of the steel is raised so rapidly that the liquid is undersaturated with respect to the corrosion products. This results in a high corrosion potential and an increase in corrosion rate.

\section{B. Interstitial Transfer}

Transfer of interstitial elements such as carbon and nitrogen in liquid sodium/stainless steel systems has been investigated in detail at a number of laboratories. ${ }^{7,17,59-74}$ Both decarburization and carburization of austentic stainless steels, viz., Types 304 and 316 with initial carbon contents of 0.05 to 0.07 wt \%, have been observed. The transfer of carbon into or out of stainless steels depends on the temperature and the carbon concentration in the sodium (1.e., the carbon activity in sodium). Based upon experimental data, two different approaches have been used to predict the kinetics of the carburization/decarburization process for austenitic stainless steels relative to the time, temperature, and carbon concentration in sodium. One method employs a one-dimensional diffusion equation with semi-infinite boundary conditions and an effective diffusion coefficient for carbon to predict carbon penetration profiles in the steel as a function of time and temperature. ${ }^{65-69}$ This analysis is similar to that used for the kinetics of carburization/decarburization behavior of ferritic steels. Effective diffusion coefficients for the transfer of carbon in stainless and ferritic steels exposed to a sodium environment are shown in Fig. 20. 
Fig. 20

Effective Diffusion Coefficients for Carbon Transfer in Austenitic and Ferritic Steels in a Sodium Environment. ANL Neg. No. 306-79-505.
TEMPERATURE $\left({ }^{\circ} \mathrm{C}\right)$

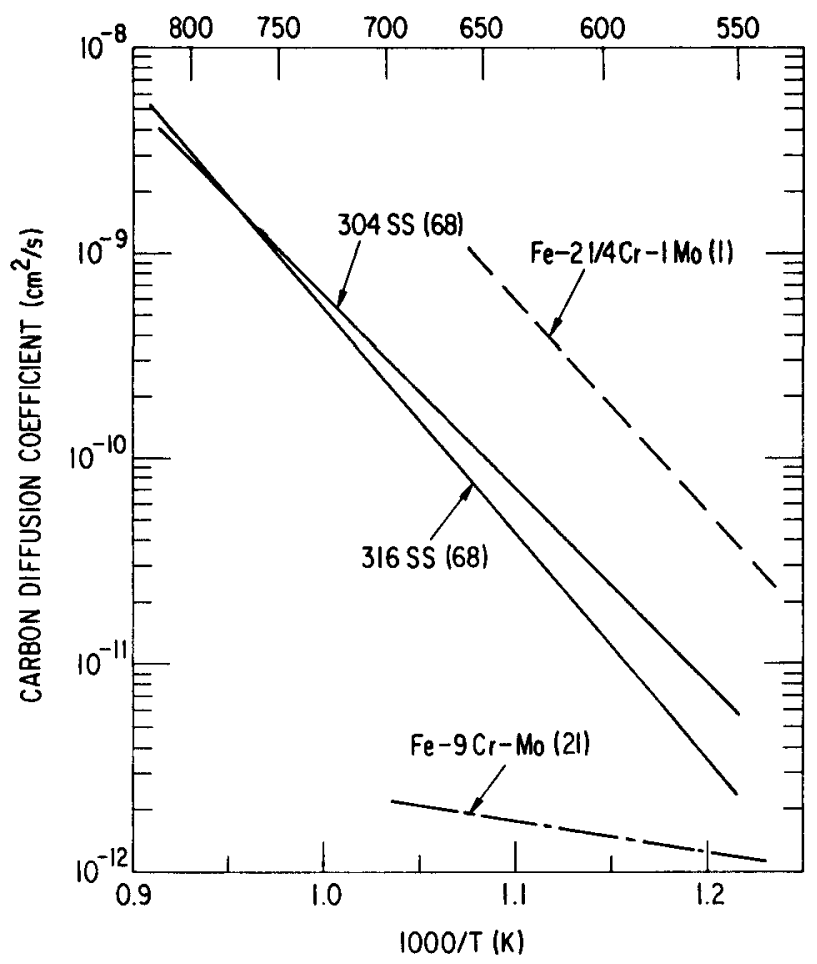

In the temperature range of 770 to $920 \mathrm{~K}$ the effective diffusion coefficient for carbon in stainless steels is lower than that of $\mathrm{Fe}-2 \frac{1}{4} \mathrm{Cr}-1 \mathrm{Mo}$ steel but is somewhat higher than for the Fe-9Cr-Mo steel. The major drawback of this approach is that the effective diffusion coefficient varies with the bulk carbon content of the steel and also depends on the carbon gradient in the steel.

The other method for analysis of the carburization/decarburization of stainless steels in sodium utilizes thermodynamic information to establish the relationship between carbon activity and carbon concentration in the stee $1^{70,71}$ and in liquid sodium. Also, the kinetics of the carburization/decarburization process were expressed relative to carbon diffusion and carbide precipitation in the steel. ${ }^{72}$ The conditions of temperature and carbon concentration in sodium that result in either carburization or decarburization of Type 304 and 316 stainless steel (with nominal initial carbon contents) are shown in Fig. 21. The results indicate that in a sodium environment containing $0.2 \mathrm{ppm}$ carbon, Types 304 and 316 stainless steel would carburize at temperatures below 940 and $900 \mathrm{~K}$, respectively. The influence of time, temperature, carbon concentration in sodium, and thermal-mechanical treatment on the carburization/decarburization behavior of Type 304 and 316 stainless steel is represented by the carbon concentration-penetration-temperature diagrams shown in Fig. 22. The region of maximum carburization is indicated by line $A$, and the penetration depth for the transition between single-phase austenite and a two-phase austenite plus carbide mixture is represented by line $B$. The variation of the carbon concentration at the surface of the steel with temperature is shown in the plane corresponding to zero penetration in the material. 
TEMPERATURE $\left({ }^{\circ} \mathrm{C}\right)$

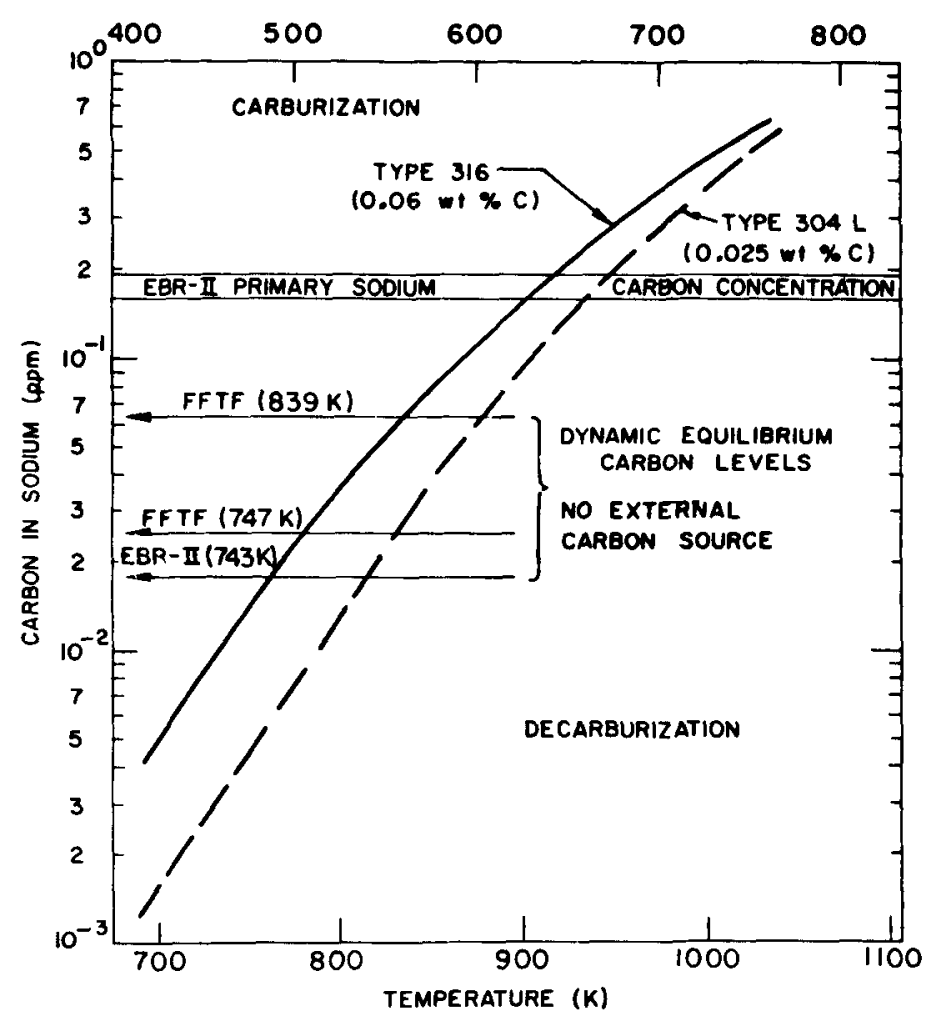

Fig. 21. Carburization-Decarburization Regimes for Types 316 and 304 Stainless Steel Relative to Temperature and Carbon Concentration in Sodium (Ref. 73). Neg. No. MSD-62604.

This mathematical analysis of the carburization/decarburization process of austenitic stainless steels has been used to assess carbon transport and the steady-state carbon concentration in sodium for large heattransport circuits. ${ }^{73}$ In sodium loops the structural material acts as the source or sink for carbon, depending upon the temperature and material composition. In addition, routine maintenance operations and leaks in components (e.g., pumps) can result in an ingress of carbonaceous material to the sodium directly or via the cover-gas system. From a knowledge of the ability of the system material to getter carbon and from the estimates of contamination rate for carbonaceous materials, it is possible to evaluate the steady-state carbon concentration in sodium and the overall carbon transport in the system. The relationship between the carbon contamination rate and the steady-state carbon concentration in the sodium for the FFTF and EBR-II primary-sodium systems is given in Fig. 23. The carbon concentration in the EBR-II primary sodium has increased from 0.11 to $0.22 \mathrm{ppm}$ over the past 6 years,* as determined from periodic equilibrations of steel foils in sodium. ${ }^{74}$ The information in Fig. 23 indicates that a carbon contamination

*Values are reported in Argonne National Laboratory Reactor Development Program Progress Reports. 


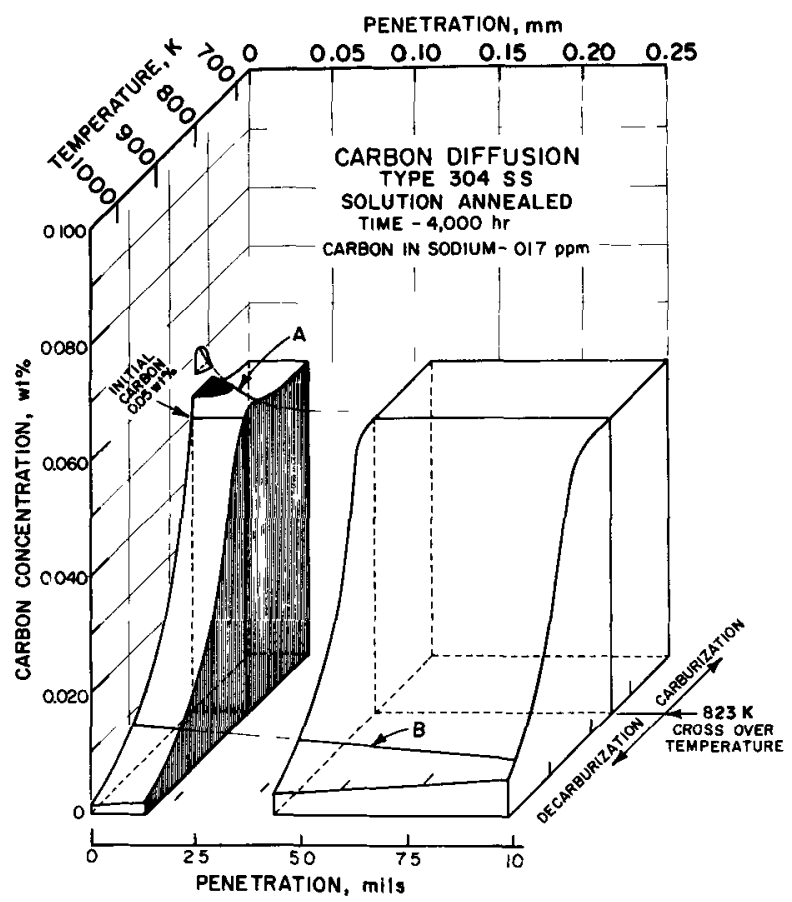

(a)

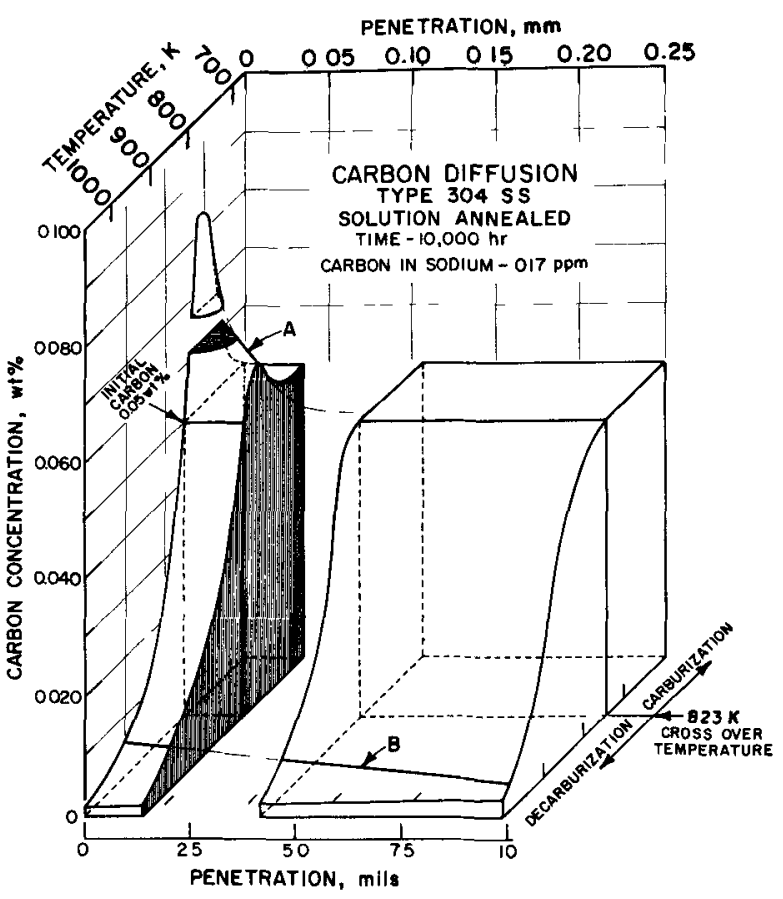

(b)

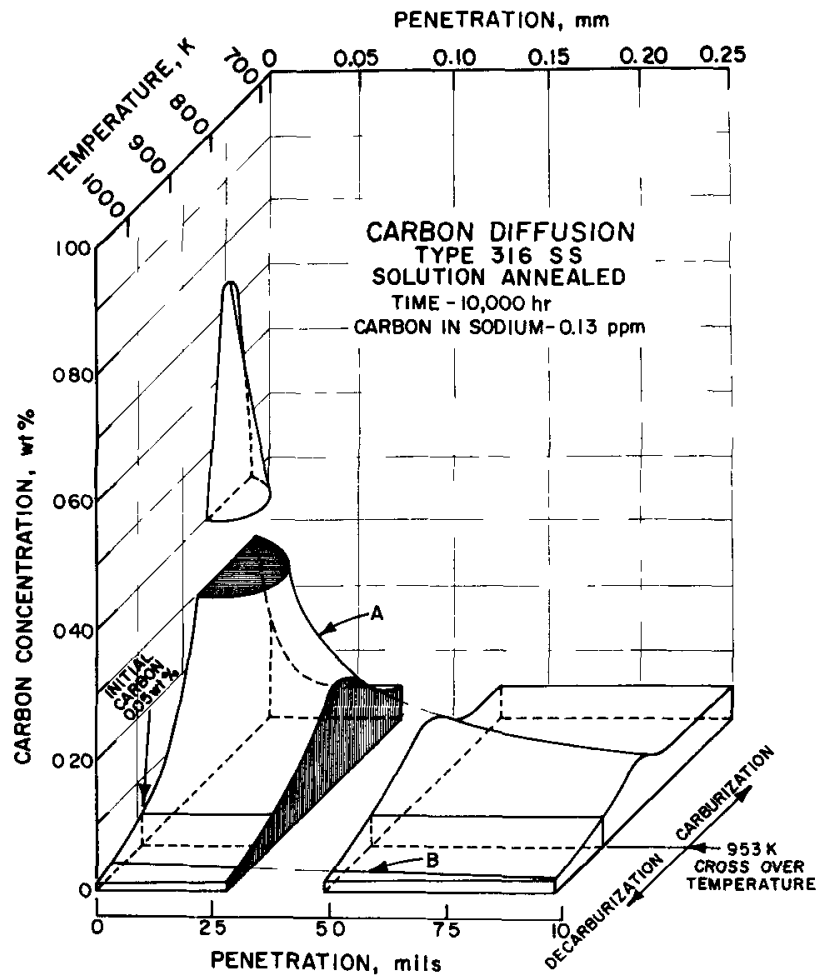

(c) 


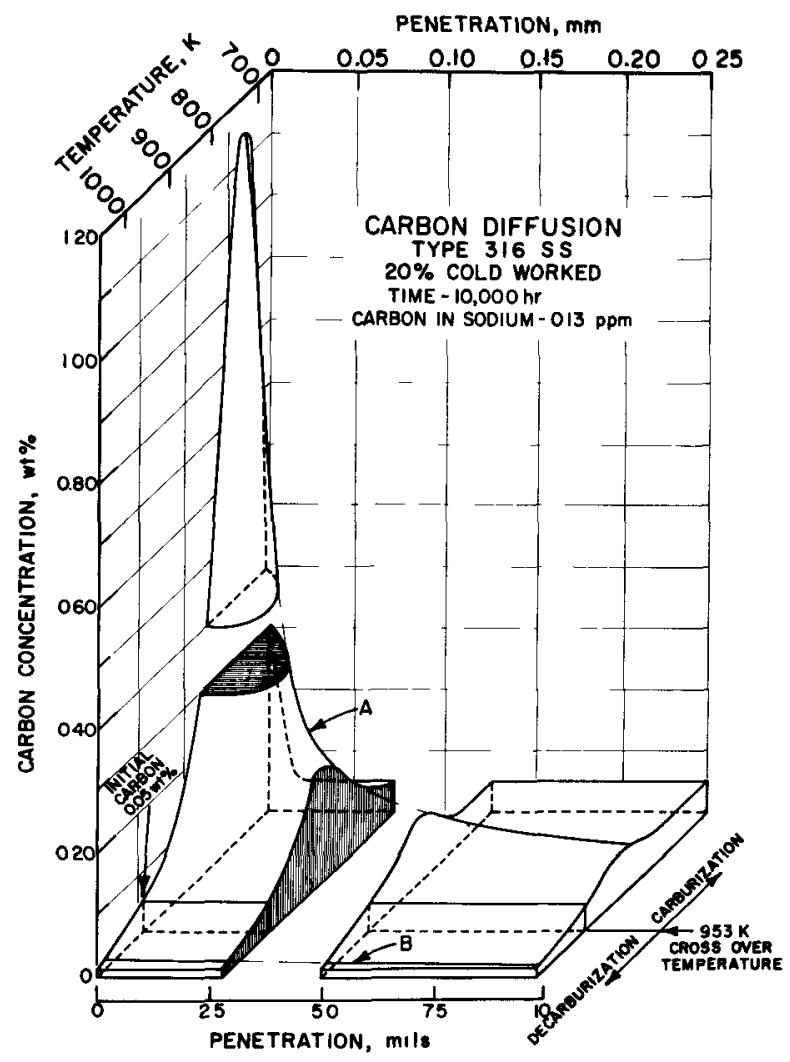

(d)

Fig. 22. Effect of Temperature on the Carburization-Decarburization Behavior of Austenitic Stainless Steels. Carbon concentration vs distance profiles in solutionannealed Type 304 stainless steel exposed to sodium, containing $0.017 \mathrm{pDm}$ carbon, for (a) $4000 \mathrm{~h}$ and (b) $10,000 \mathrm{~h}$; carbon concentration vs distance profiles in (c) solution-annealed and (d) $20 \%$ coldworked Type 316 stainless steel after $10,000-\mathrm{h}$ exposure to sodium containing $0.13 \mathrm{ppm}$ carbon. (Ref. 72). Neg. Nos. MSD-58339, 58240, 58564 and 58565.

rate of $\sim 250$ to $\sim 300 \mathrm{~g} / \mathrm{y}$ would result in such carbon levels in sodium. The low operating temperatures coupled with relatively minor contamination of the sodium by carbonaceous material have resulted in minimal composition changes in the austenitic steels in this circuit.

An analysis based on an effective diffusion coefficient has been used to determine the kinetics of nitrogen transfer in sodium/stainless steel systems. In general, stainless steels pick up nitrogen at temperatures below $\sim 810 \mathrm{~K}$ and lose nitrogen at higher temperatures. ${ }^{8}$ The extent of nitrogen transfer depends on the sodium chemistry, temperature, and the purity of the argon cover gas used in liquid-sodium systems. For example, the cover gas typically contains 0.25 to 0.5 vol \% nitrogen as an impurity. Consequently, nitridation of materials in the cover-gas region of sodium 


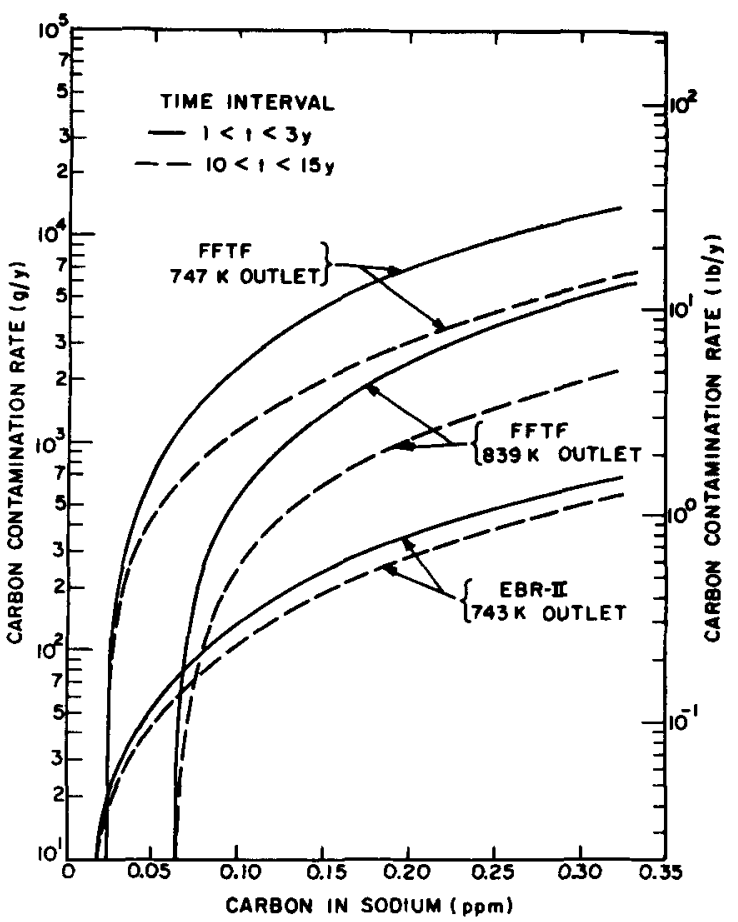

F1g. 23

Relationship between Carbon Contamination Rate in FFTF and EBR-II Primary Systems and Steady-state Carbon Concentration in the Sodium (Ref. 73). Neg. No. MSD-62605.

systems can be a potential problem. The effective diffusion coefficient for nitrogen in stainless steels is shown in Fig. 24.

Fig. 24

Effective Diffusion Coefficient for Nitrogen Transfer in Austenitic Stainless Steels in a Sodium Environment. ANL Neg. No. 306-79-506.

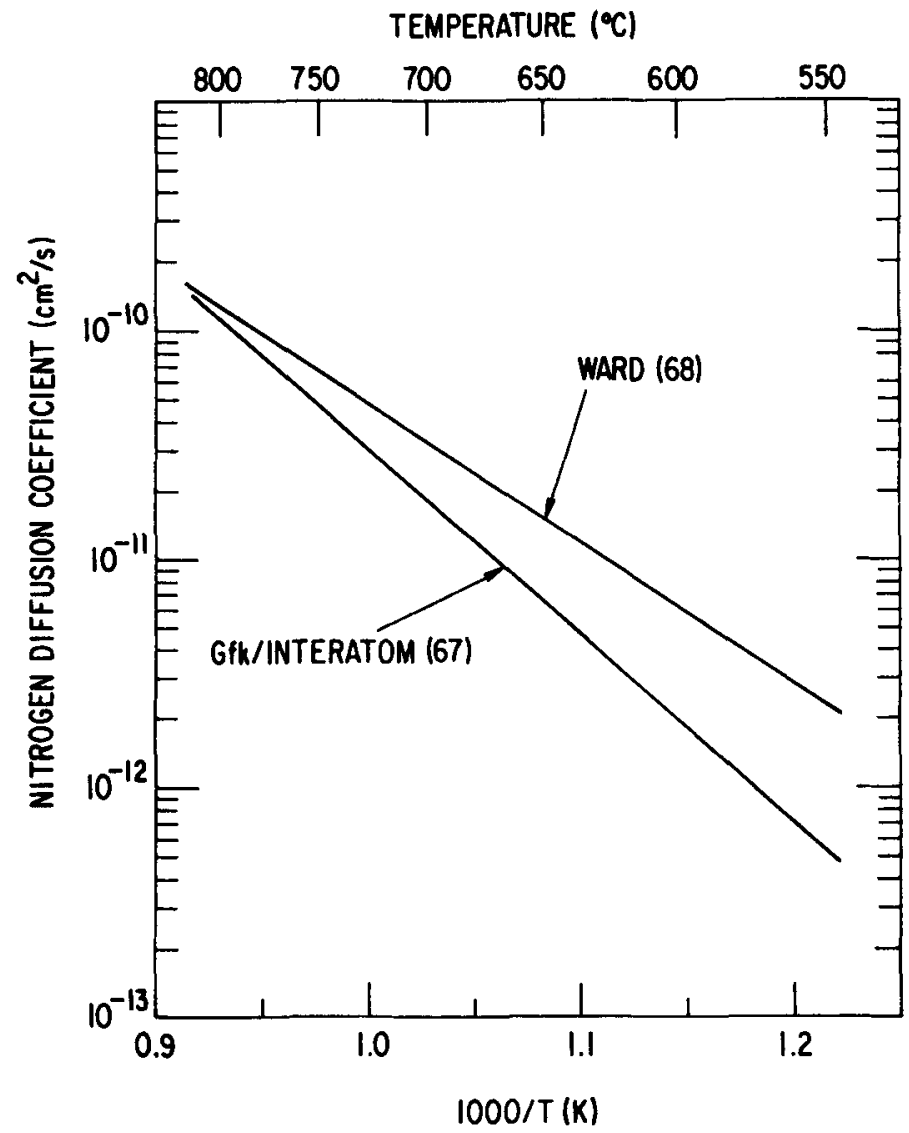




\section{Mechanical Properties}

The influence of carburization/decarburization on the mechanical properties of austenitic stainless steels has been the subject of numerous investigations. Tensile and creep-rupture data have been obtained from materials which were carburized in sodium to produce specific carbon-penetration depths. At temperatures between 670 and $1070 \mathrm{~K}$ the ultimate tensile elongation decreases with an increase in carbon concentration in the material. $33,47,75-80$ Figures $25-27$ show the variation in the ultimate strength, uniform elongation, and total elongation for Types 304 and 316 stainless steel after exposure to a sodium environment at temperatures between 700 and $970 \mathrm{~K}$. For these tests, the depth of carbon penetration In the specimens varied from 0.1 to $0.3 \mathrm{~mm}$ and the increase in average bulk carbon concentration of these specimens was up to $0.2 \mathrm{wt} \%$ for Type 316 and 0.15 wt \% for Type 304 stainless steel. The effect of sodium exposure on the tensile properties is greater at lower temperatures because of the greater pickup of carbon at these temperatures.

Creepnrupture data for austenitic stainless steels carburized in a sodium environment show an increase in rupture life and a decrease in minimum creep rate when compared with annealed material.81,85 Type 316 stainless steel exposed to sodium at $823 \mathrm{~K}$ is an exception to this behavior,

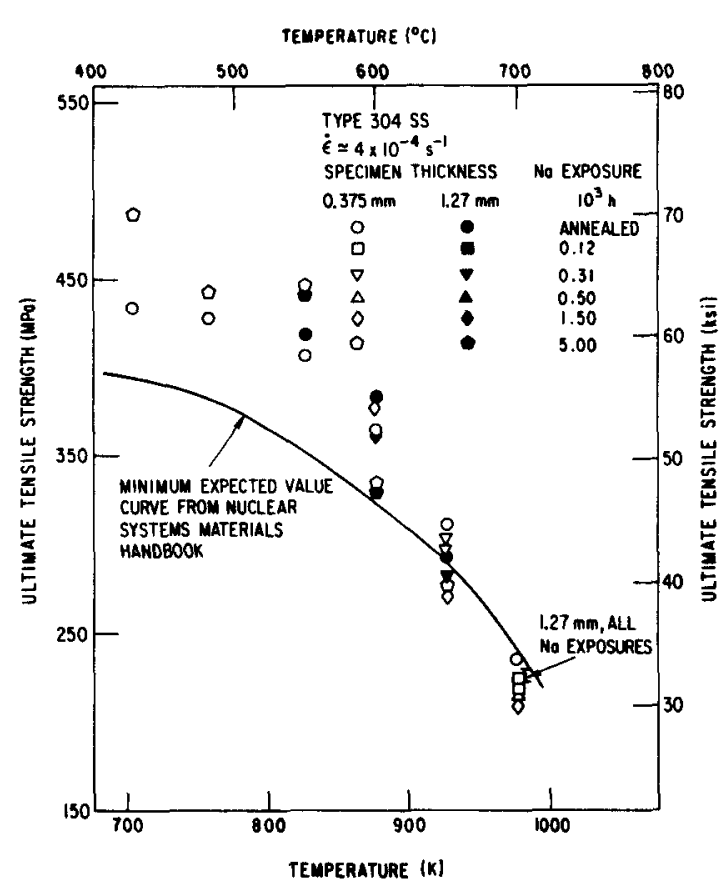

(a)

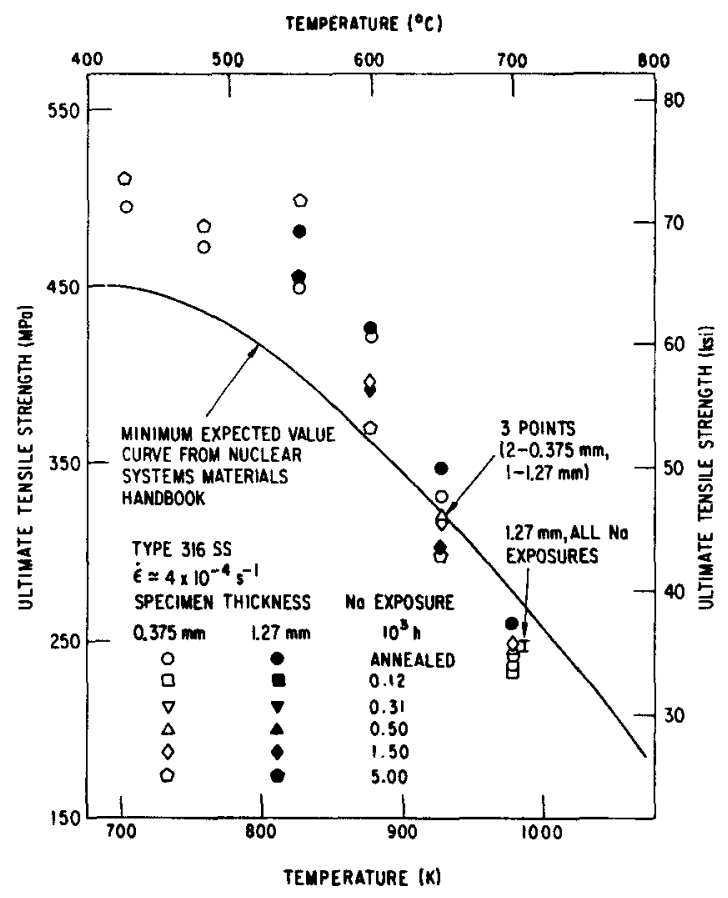

(b)

Fig. 25. Effect of Sodium Exposure on the Ultimate Tensile Strength of (a) Type 304 and (b) Type 316 Stainless Steels. ANL Neg. Nos. 306-78-302 Rev. 1 and 30678-303 Rev. 1 . 


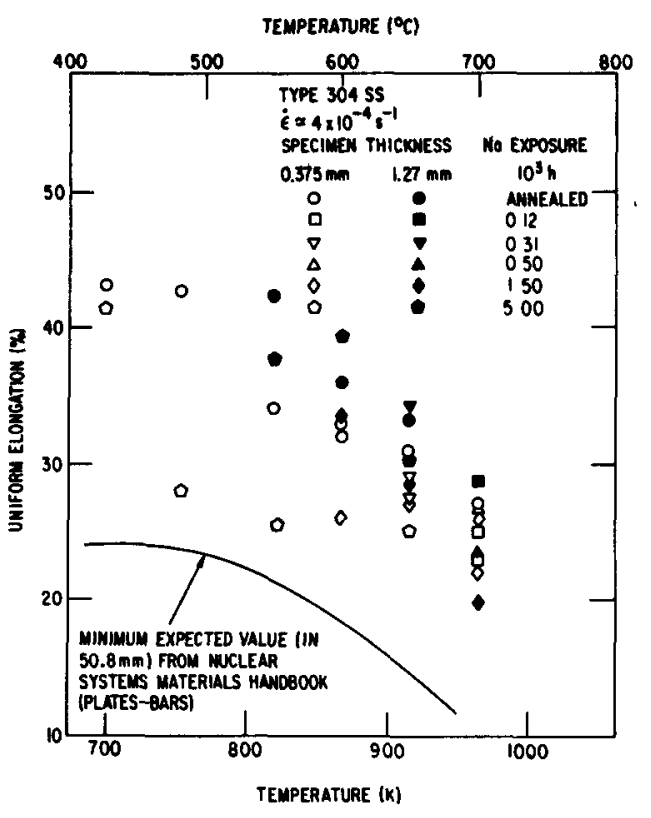

(a)

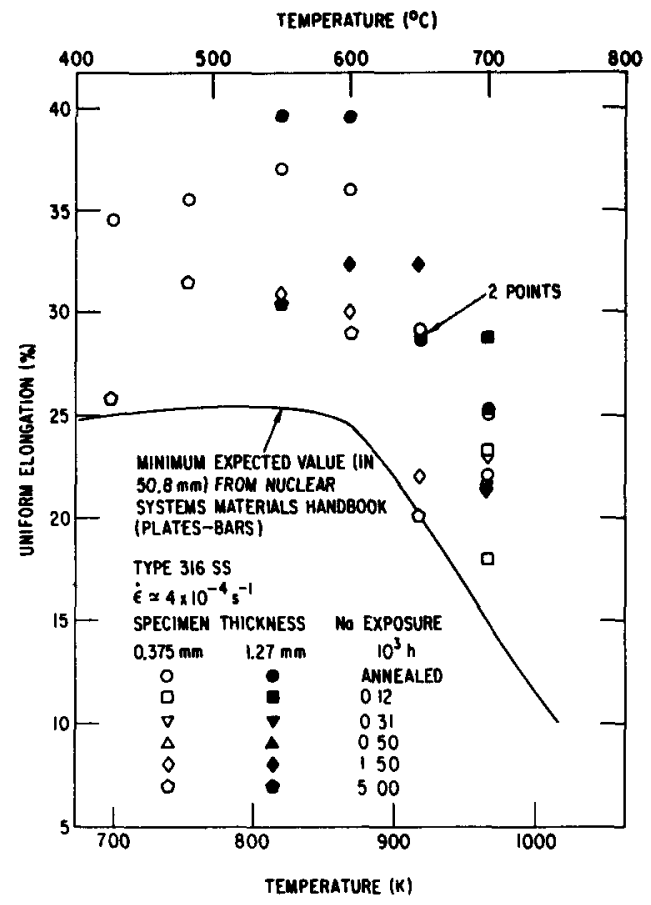

(b)

Fig. 26. Effect of Sodium Exposure on the Uniform Elongation of (a) Type 304 and (b) Type 316 Stainless Steels. ANL Neg. Nos. 306-78-305 Rev. 1 and 306-78-304 Rev. 1.

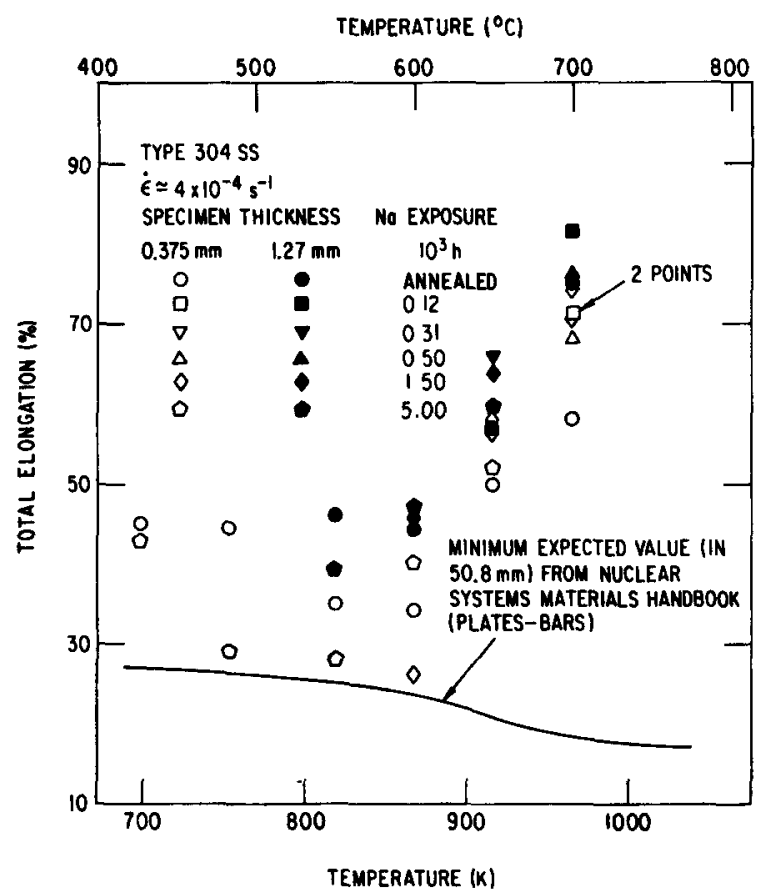

(a) 


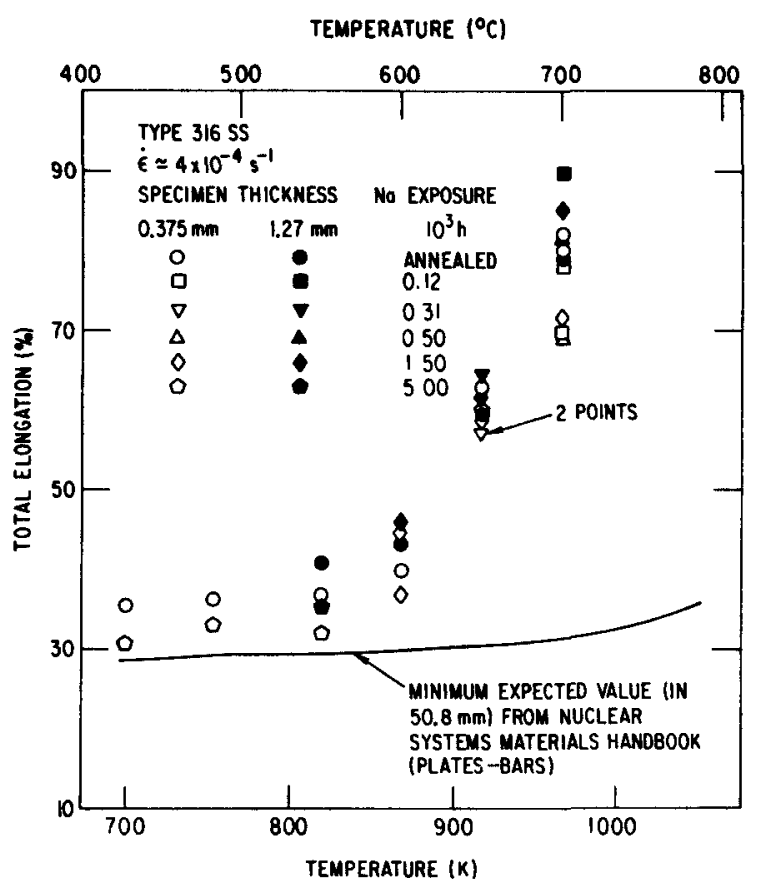

(b)

Fig, 27. Effect of Sodium Exposure on the Total Elongation of (a) Type 304 and (b) Type 316 Stainless Steels. ANL Neg. Nos. 306-78-310 Rev. 1 and 306-78-311 Rev. 1 .

i.e., a small decrease in rupture life occurs due to carburization. ${ }^{85}$ Tests performed in sodium indicate that the environment itself has little or no effect on creeprrupture behavior of stainless steels. ${ }^{4}$ The influence of carburization on the creepmrupture properties of Types 304 and 316 stainless steel is shown in Figs. 28 and 29, respectively, for the temperature
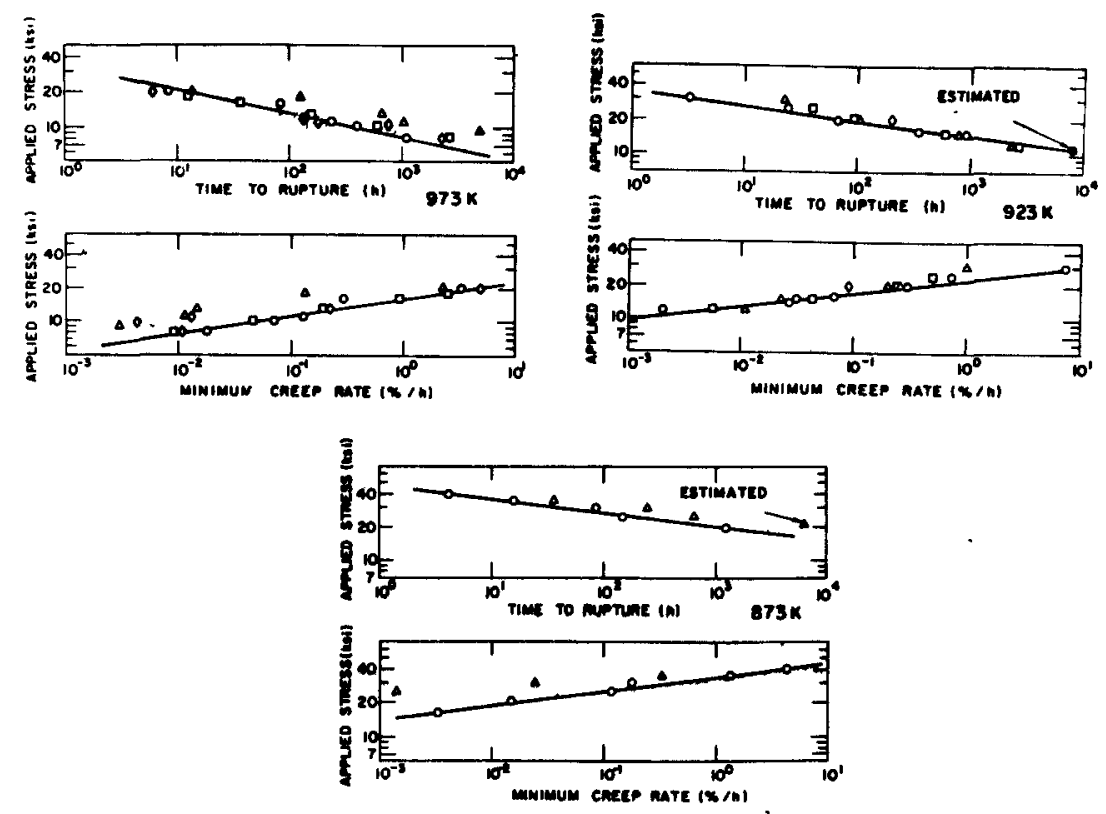

Fig. 28

Variation of Time to Rupture and Minimum Creep Rate with Applied Stress for Type 304 Stainless Steel at 973 , 923 , and $873 \mathrm{~K}$.

Carburization depths: $\Delta=100 \mu \mathrm{m}, \square=$ $200 \mu \mathrm{m}$, and $\circlearrowright=375 \mu \mathrm{m}$. $\mathrm{O}=$ solution annealed (Ref. 85). Neg. No. MSD-62387. 

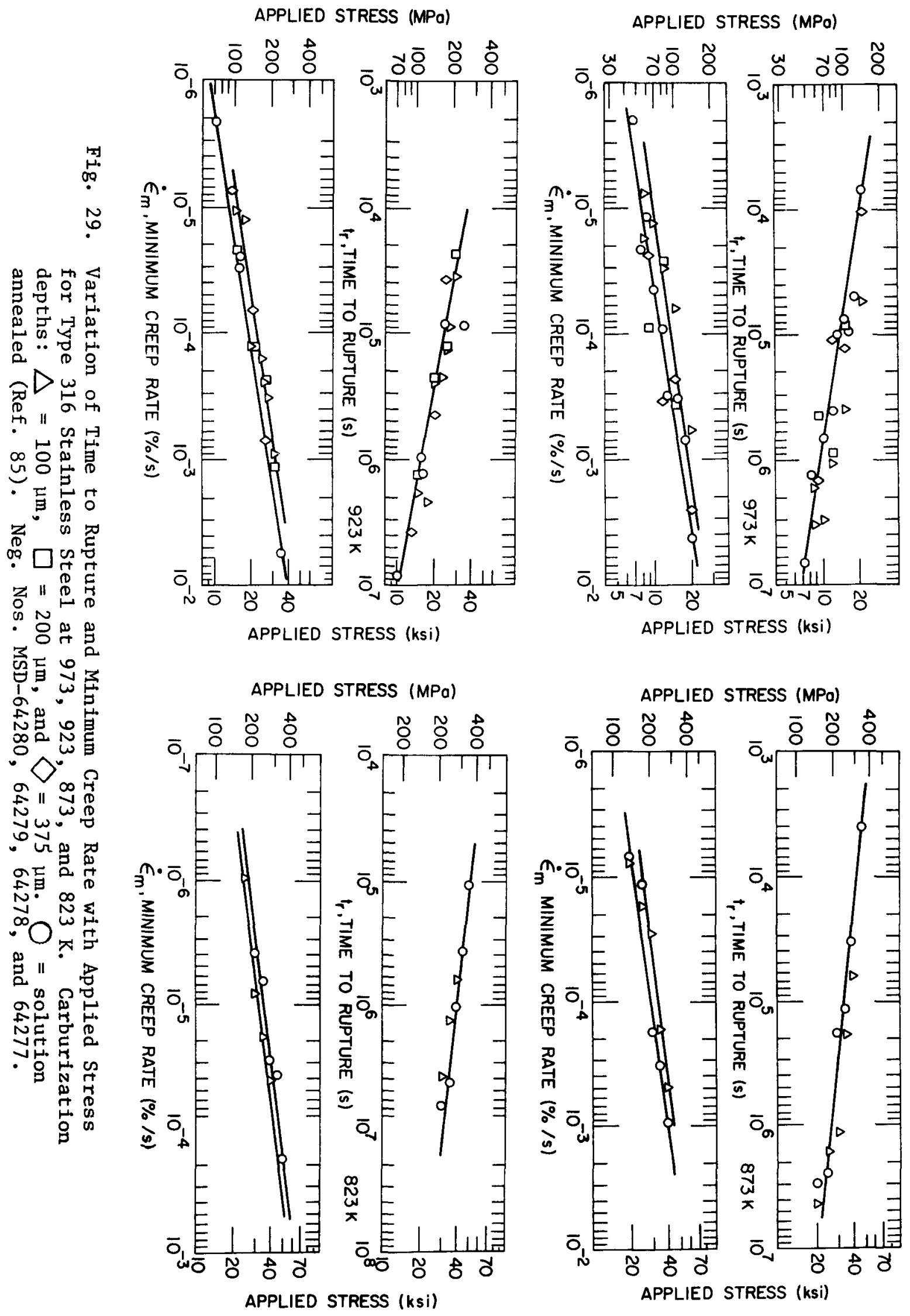
range from 820 to $970 \mathrm{~K}$. The results show an increase of 15 to $30 \%$ in the $10^{5}$-h creep-rupture stress for carburized material. Microstructural examination of the creep-tested specimens indicated that carburization of the material inhibits intergranular failure that is generally observed in austenitic steels at low strain rates. 79

A1though carbon, nitrogen, and boron increase the tensile and creeprupture strengths of austenitic stainless steels, ${ }^{86-88}$ the strengthening effects of these interstitial elements cannot be realized in material exposed to high-temperature sodium $(2870 \mathrm{~K})$. The limited data available on stress-rupture life of austenitic stainless steels after exposure to hightemperature sodium show a reduction in the creep-rupture life and creep ductility, when compared to the control tests in helium. ${ }^{81}$ The decrease in the creep-rupture properties was attributed to the changes in the microstructure and the formation of sigma phase as a result of the loss of carbon and nitrogen from the steel. Sigma phase in Type 316 stainless steel has been known to cause a degradation of mechanical properties.

Investigations of the effect of thermal aging on the microstructural changes in stainless steels via time-temperature-precipitation (TTP) diagrams have shown that the stability of intermetallic phases, such as sigma phase, increases with a decrease in either carbon or nitrogen concentrations in austenitic stainless steels. ${ }^{89,90}$ TTP diagrams and data on the influence of interstitial elements on the mechanical properties provide a basis for comparison of the tensile and creep-rupture properties of stainless steels in air, inert gas, and sodium environments. ${ }^{75}$ The results indicate that sodium per se does not alter the tensile and creep-rupture properties. The changes in microstructure and mechanical properties that result when stainless steels undergo decarburization in sodium are quite similar to those observed when low-carbon heats of these steels are exposed to the same thermal treatment. Decreases in carbon and nitrogen concentrations in Types 304 and 316 stainless steel during exposure to high-temperature sodium result in a 25 to $35 \%$ reduction in the $10^{5}$-h creep-rupture strength.

Investigations of the effect of sodium on the low-cycle fatigue properties of stainless steels indicate that both the environment and microstructural changes due to sodium exposure influence the fatigue life.91-95 Figure 30 shows the fatigue life of Types 304 and 316 stainless steel in sodium at 823,873 , and $973 \mathrm{~K}$. The results indicate that the fatigue life of Type 316 stainless steel is a factor of 3 to 10 greater in sodium than in air, whereas the fatigue life of Type 304 stainless steel does not differ substantially in the two environments. The difference between the data for Type 316 stainless steel obtained at ANL and at WARD is believed to be due to different initial heat treatments. Results from both studies show a beneficial effect of the sodium environment in relation to results obtained in air (Fig. 30b). Thermal aging or sodium exposure has a minimal effect on the fatigue life of Type 316 stainless steel. At 873 and $973 \mathrm{~K}$ the fatigue life of Type 304 stainless steel in the sodium-exposed and thermally aged conditions is greater than that of solution-annealed material. 


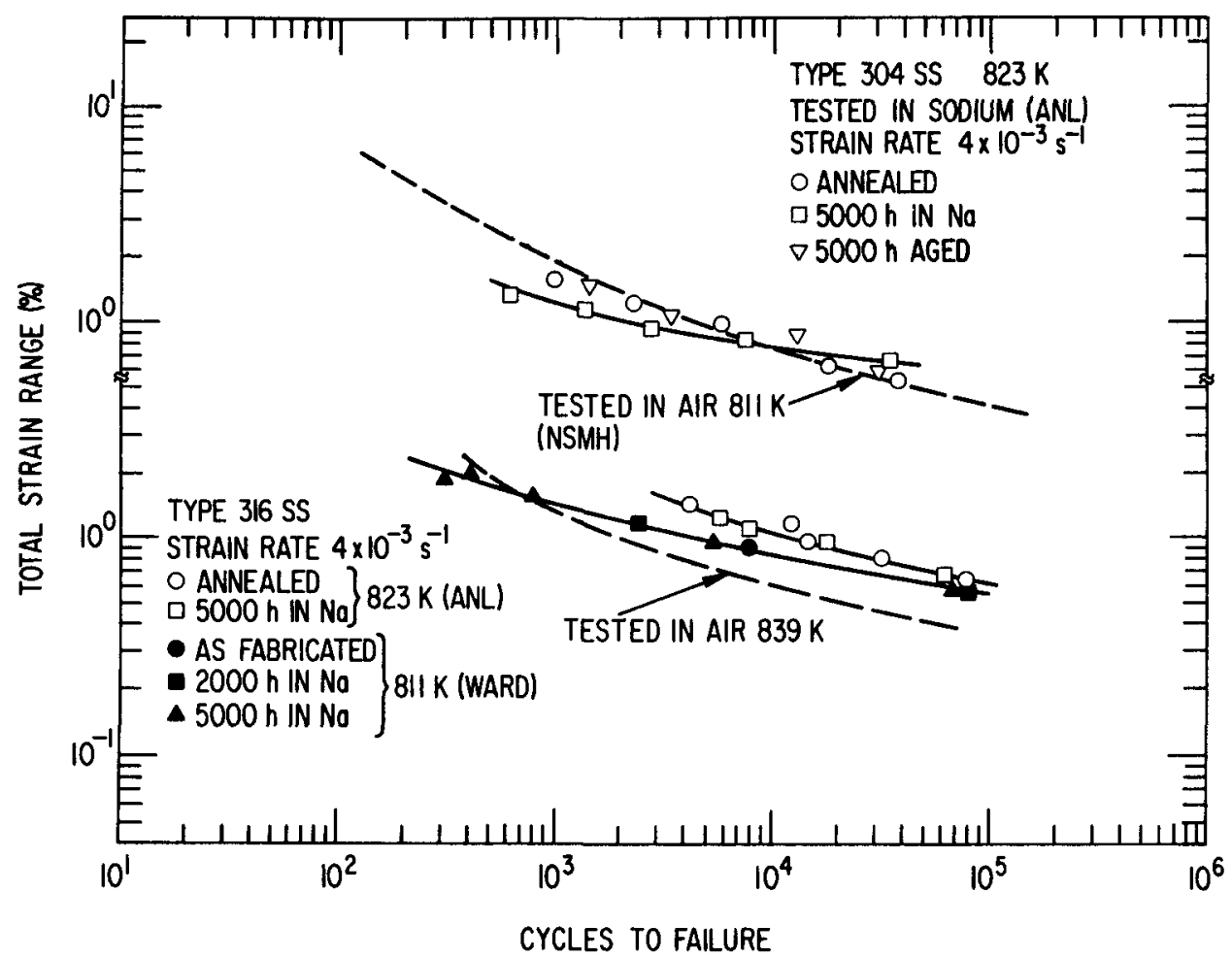

(a)

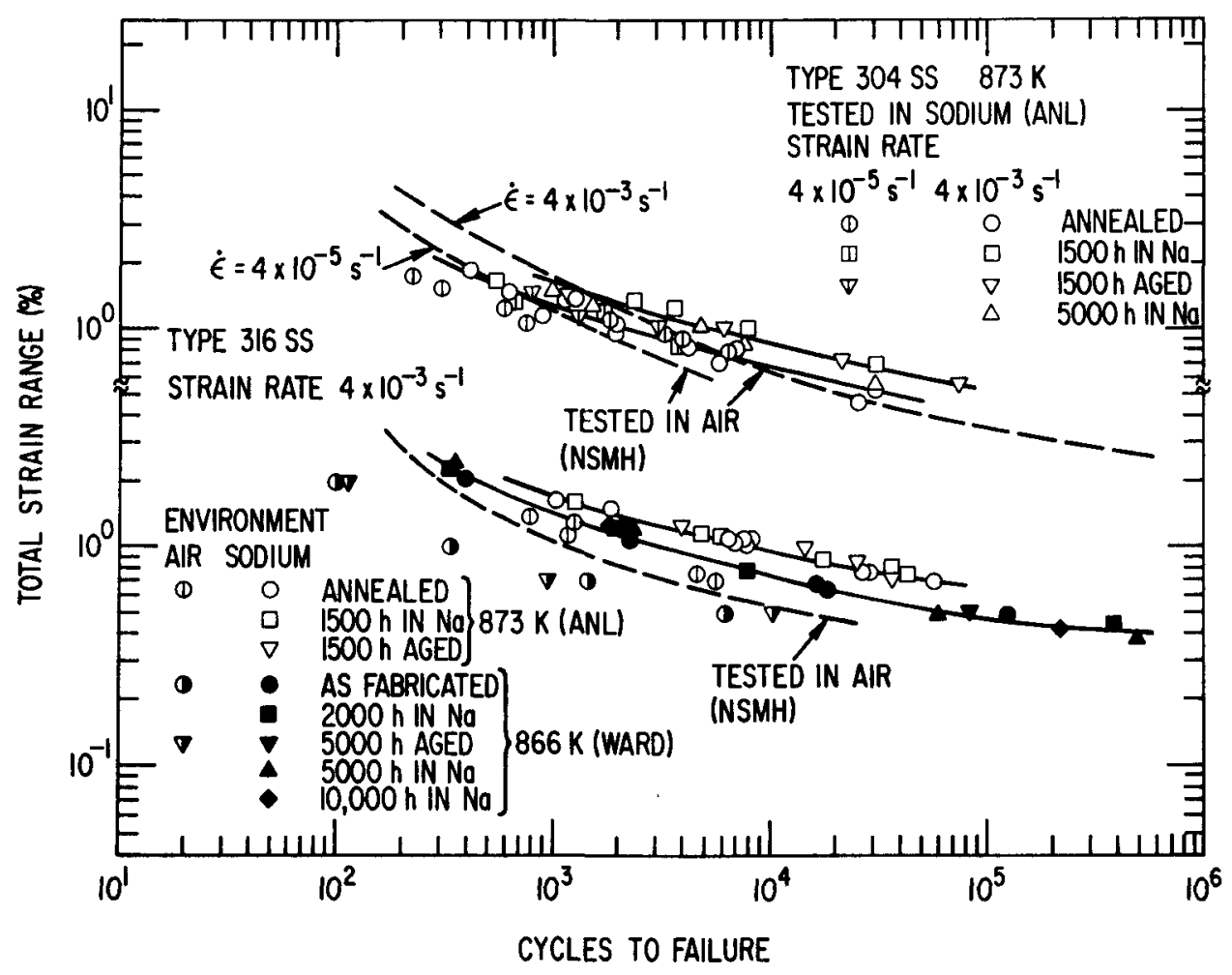

(b) 


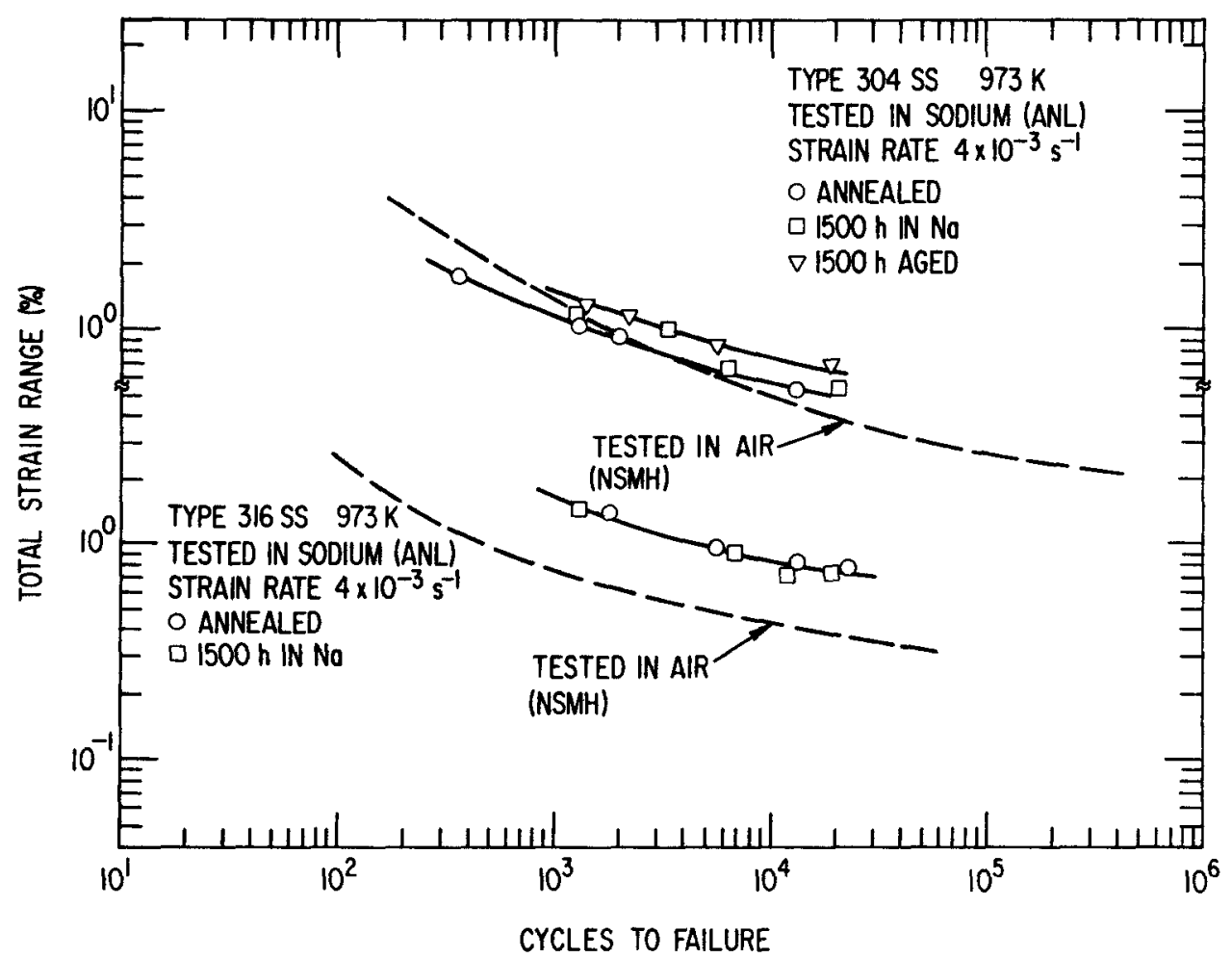

(c)

Fig. 30. Fatigue-1ife Curves for Types 304 and 316 Stainless Steel Tested in Air and Sodium at Temperatures between 811 and $973 \mathrm{~K}$. (Data obtained from Refs. 91-95.) ANL Neg. Nos. 306-79-507, 306-79508, and 306-79-509.

The creep-fatigue interaction behavior of stainless steels in a sodium environment has not been evaluated. Fatigue life for Type 304 stainless steel at a strain rate of $4 \times 10^{-5} \mathrm{~s}^{-1}$ in sodium at $873 \mathrm{~K}$ is shown in Fig. 30b. These results indicate that the effect of strain rate on fatigue life in a sodium environment is similar to that observed in air, i.e., the fatigue lifetime decreases with a decrease in strain rate.

The effect of sodium environment on fatigue-crack growth of Type 304 stainless steel has been investigated. 96 The results show that the fatiguecrack growth rates in sodium at 700 and $811 \mathrm{~K}$ are considerably lower than in an air environment at the same test temperatures (Fig. 31). Crack-growth rates at these temperatures are approximately the same as those for tests conducted in room-temperature air. A temperature-independent fatigue-crack growth rate in sodium indicates that the thermally activated component of crack growth observed in an air environment may be due to an environmental interaction. An increase in crack-growth rates (i.e., decrease in fatigue 1ife) in an air environment as the temperature increases or as the strain rate decreases has generally been attributed to a "creep component" or to creep-fatigue interaction and not to environmental effects. Additional data are required to evaluate the effect of a sodium environment on creep-fatigue interaction of stainless steels. 


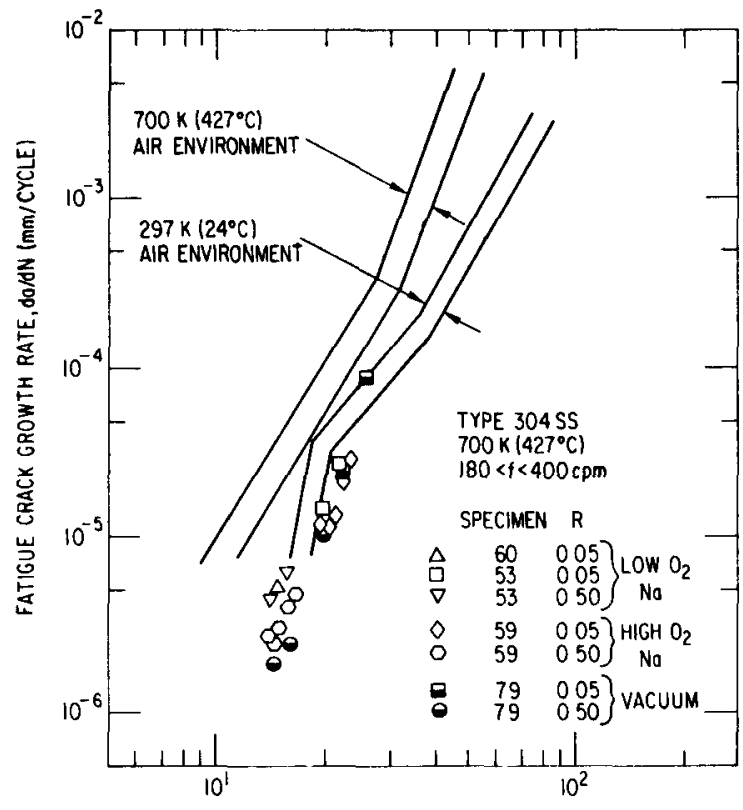

EFFECTIVE STRESS INTENSITY FACTOR, $\mathrm{K}_{\max }[1-\mathrm{R}]^{06}\left(\mathrm{MN} / \mathrm{m}^{3 / 2}\right)$

Fig. 31. Fatigue Crack-propagation Behavior of Annealed Type 304 Stainless Steel in Sodium at $700 \mathrm{~K}$ (replotted from data in Ref. 96). ANL Neg. No. 306-79-510.

\section{BEHAVIOR OF ALLOY 800 IN SODIUM}

Alloy 800 has also been used in the construction of sodium-heated steam generators. This alloy has a greater resistance to stress-corrosion cracking in caustic- or chloride-contaminated aqueous environments than austenitic stainless steels and has better elevated-temperature strength and resistance to sodium-water wastage damage than ferritic $\mathrm{Fe}-2 \frac{1}{4} \mathrm{Cr}-1$ Mo steel. Alloy 800 is used extensively in construction of components in chemical and petrochemical process plants and has accumulated favorable service experience as a superheater tube material both in fossil-fueled power plants and in high-temperature gas-cooled reactors (HTGRs). 97-100 Alloy 800 has also been used for steam-generator tubes in pressurized-water reactor (PWR) and pressurized-heavy-water reactor (PHWR) power plants.101, 102 However, information on the sodium-corrosion behavior and the effect of sodium exposure on the mechanical properties of Alloy 800 is limited.

\section{A. Corrosion}

The corrosion behavior of Alloy 800 in flowing sodium is similar to that of the austenitic stainless steels. ${ }^{18,53,103-106}$ For example, after an initial corrosion period the metal loss is linear with time, i.e., the corrosion rate reaches a steady-state value. Available data on the corrosion rate for Alloy 800 in sodium at temperatures between 873 and $990 \mathrm{~K}$ are shown in Fig. 32. The corrosion rates are approximately 2-3 times higher than those for Type 316 stainless steel. However, the test temperatures are relatively high and additional data at lower temperatures are required to establish the temperature dependence of the corrosion rate for Alloy 800 . 
TEMPERATURE ( $\left.{ }^{\circ} \mathrm{C}\right)$

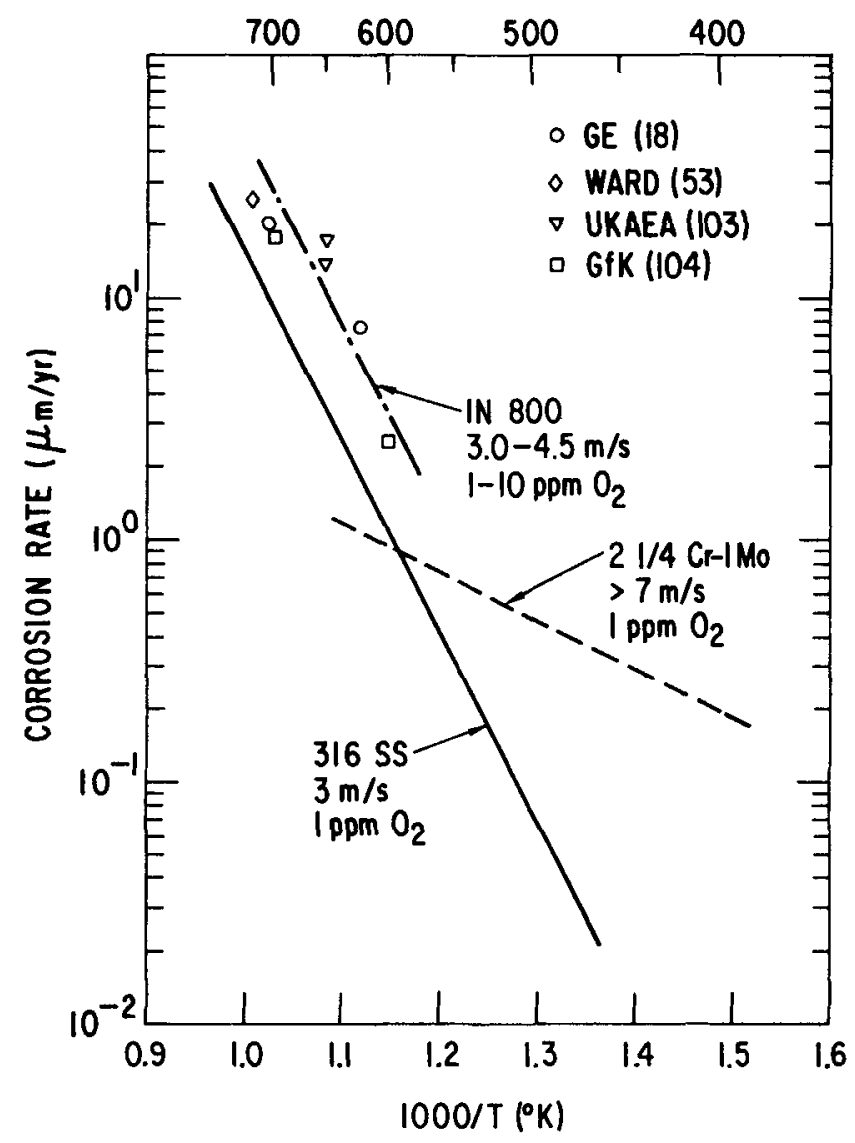

Fig. 32. Corrosion-rate Data for Alloy 800 in Flowing Sodium at Temperatures between 870 and $990 \mathrm{~K}$. ANL Neg. No. 306-79-511.

Several important differences have been noted between the microstructural changes in Alloy 800 and stainless steel after exposure to a high-temperature sodium environment. When exposed to sodium at $977 \mathrm{~K}$, Alloy 800 is susceptible to subsurface void formation and grain detachment. $18,53,105,106$ The size and depth of penetration of the cavities increase with sodium-exposure time. In general, the cavities initiate at the sodium-exposed surface and tunnel into the material along grain boundaries to depths of $\sim 100$ to $130 \mu$ from the surface. X-ray analyses of the surfaces show progressive loss of substitutional elements, e.g., chromium, nicke1, and manganese, as the exposure time increases. Surface-element depletion in stainless steel leads to the formation of an iron-rich ferritic layer; however, a ferrite layer has not been observed in Alloy 800 specimens.

At present, the mechanism and the range of conditions for the formation of subsurface cavities are not well established. Subsurface cavities have been observed in other stabilized alloys, e.g., Types 321 and 347 stainless steel, but not in the unstabilized Types 304 and 316 stainless steel. In 
general, the corrosion rates are higher for the stabilized than for the unstabilized steels under equivalent test conditions.107 Figure 33 shows the subsurface structure of three steels after exposure to sodium at $977 \mathrm{~K}$ for $15,726 \mathrm{~h}$. In recent work at CEA, 5- $\mu \mathrm{m}$-deep cavities were observed after exposure to sodium at $883 \mathrm{~K}$ for $10,000 \mathrm{~h} .106$ Figure 34 shows that the depth of penetration $(P)$ of the subsurface cavity follows a parabolic relationship with time $(t)$, i.e., $P=0.864 \mathrm{t}^{1 / 2}$. This behavior indicates that the process of cavity formation is diffusion controlled. Further studies are required to establish the validity of this relationship over a wider temperature range and to determine whether cavity formation occurs after 1onger sodium-exposure times at lower temperatures.

\section{B. Interstitial Transfer}

Information on the carburization/decarburization behavior of Alloy 800 is sparse.104,105,108 The equilibrium carbon concentration for Alloy 800 has been obtained at various carburizing potentials in sodium at temperatures between 866 and $1033 \mathrm{~K} .108$ Data for the equilibrium carbon concentration are shown in Fig. 35 as a function of carbon activity in sodium. The values of carbon activity were obtained from the equilibrium carbon concentration in Type 304 stainless steel specimens, which were exposed with Alloy 800, and the carbon concentration-carbon activity relationship for Type 304 stainless steel.71,72 These results indicate that an alloy with a nominal carbon concentration of 0.07 wt \% will decarburize at temperatures above $~ 890$ and $980 \mathrm{~K}$ when exposed to sodium containing $\lesssim 0.05$ and $0.20 \mathrm{ppm}$ carbon, respectively; and will carburize at lower temperatures. The equilibrium carbon concentrations predicted by this relationship, however, are a factor of 3 lower than the surface carbon concentrations observed in Alloy 800 specimens exposed for $10,400 \mathrm{~h}$ at 873 and $973 \mathrm{~K}$ in sodium containing $0.2 \mathrm{ppm}$ carbon. 104 The change in bulk carbon concentration of Alloy 800 after exposure to sodium at $977 \mathrm{~K}$ for times up to $\sim 11,400 \mathrm{~h}^{105}$ yields values of 2 to $8 \times 10^{-8} \mathrm{~g} / \mathrm{cm}^{2} \mathrm{~s}^{1 / 2}$ for the carburization rate constant. Additional data on carburization/decarburization behavior are required to establish the equilibrium carbon concentration-carbon activity relationship and the temperature dependence of the rate constant for Alloy 800.

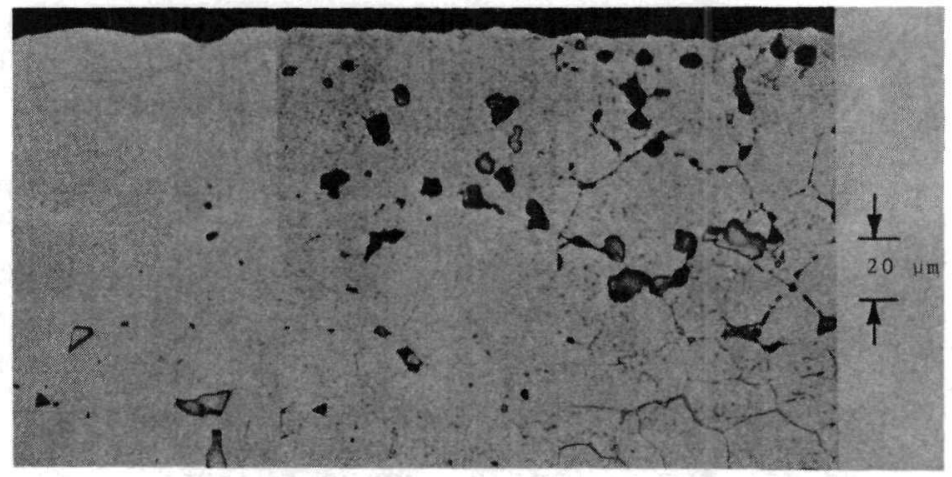

Material: $\quad$ Type $304 \quad$ Type $321 \quad$ Alloy 800

Fig. 33. Microstructures of Several Alloys after Exposure to Flowing Sodium for 15,726 h at $980 \mathrm{~K}$ (Ref. 105). Permission has been granted by the copyright holder for reproduction of this figure. 


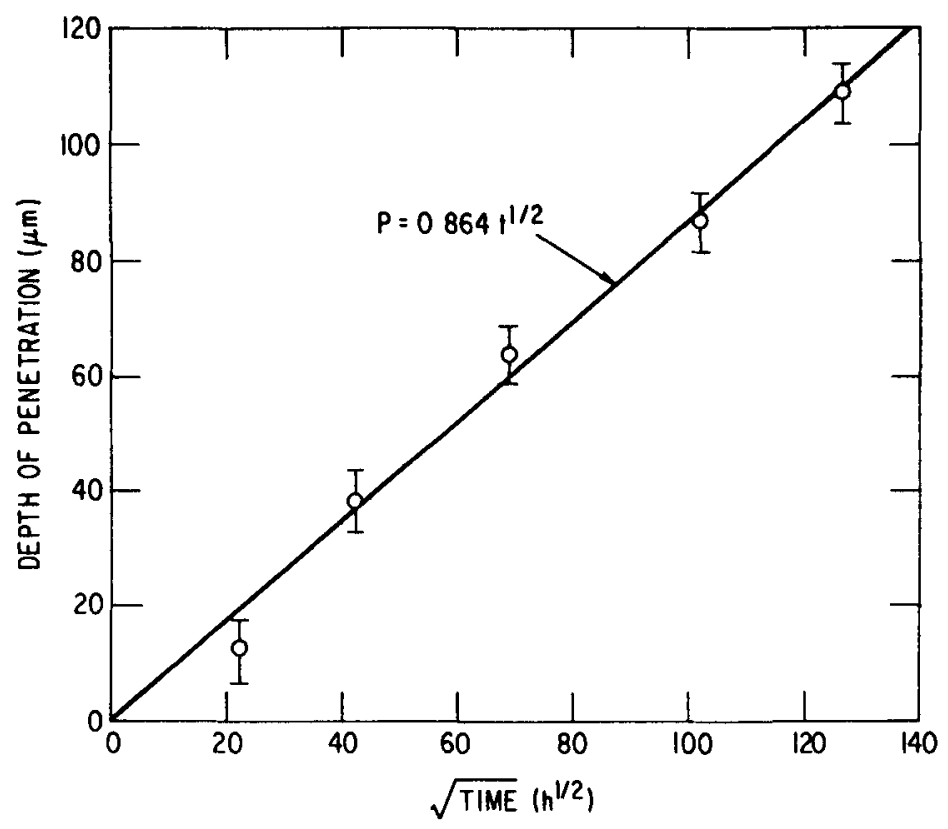

Fig. 34. Relationship between Depth of Intergranular Penetration and Exposure Time for Alloy 800 (Ref. 105). ANL Neg. No. 306-79-512. Permission has been granted by the copyright holder for reproduction of this figure.

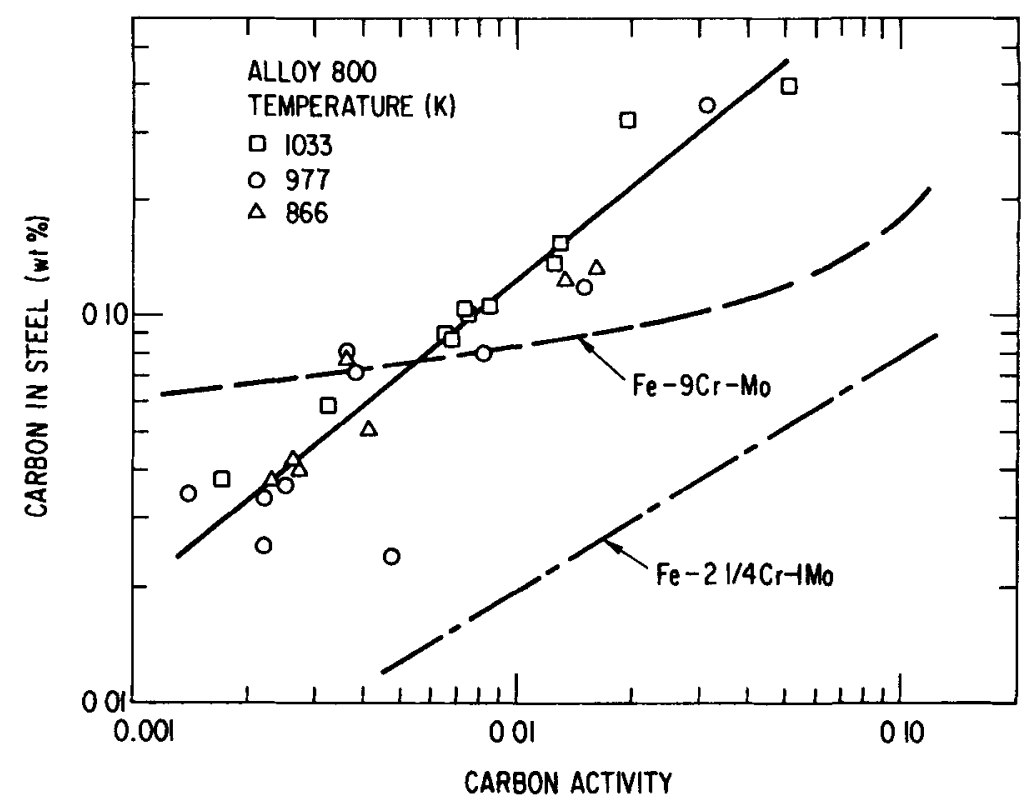

Fig. 35. Carbon Activity-Concentration Relationship for Alloy 800 at Temperatures between 866 and $1033 \mathrm{~K}$ (Ref. 108). ANL Neg. No. 306-79-513.

\section{Mechanical Properties}

Current knowledge of the effect of sodium exposure on the mechanical properties of Alloy 800 is quite limited. Uniaxial creep-rupture tests have been conducted either on tube specimens filled with sodium 109,110 or on 
flat-notch specimens in static sodium. ${ }^{111}$ The results in Fig. 36 show that at $973 \mathrm{~K}$, the creep-rupture life and ductility are significantly reduced in sodium when compared to those in an air or inert-gas environment. The principal effect of the sodium environment was to greatly reduce the time of tertiary creep for the tube specimens and to change the mode of creep failure from transgranular to intergranular cracking for the notch specimens. Tensile tests in static sodium at $973 \mathrm{~K}$ show considerable intergranular cracking and a reduction in tensile strength and elongation. ${ }^{11}$ These tests were conducted in sodium of unspecified purity and the mechanical properties were not related to the structural and compositional changes that occur in the material during exposure to the environment. Data are not available on the effect of 1ong-term sodium exposure on the mechanical properties of Alloy 800 .

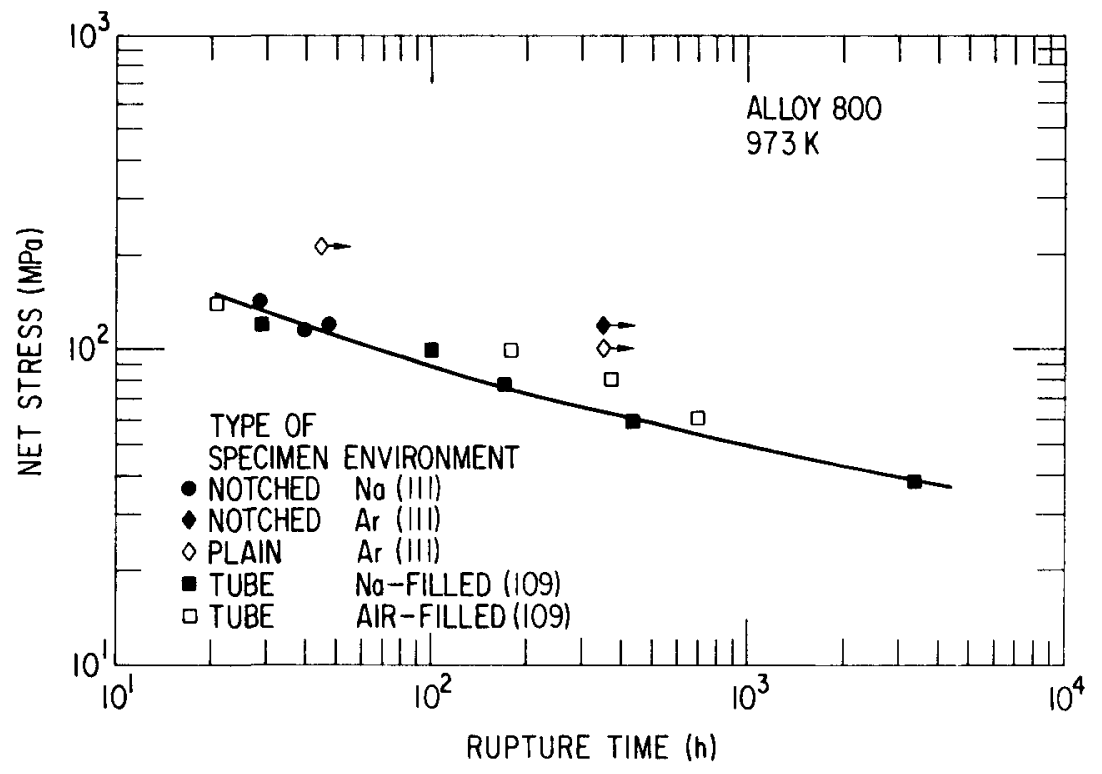

Fig. 36. Creep-rupture Behavior of Alloy 800 in Sodium and Argon Environments. ANL Neg. No. 306-79-514.

\section{SPECIAL CONSIDERATIONS}

\section{A. Tube Wastage by $\mathrm{Na}-\mathrm{H}_{2} \mathrm{O}$ Reactions}

The relative resistance of materials to wastage or accelerated corrosion by products from the sodium-water reaction, in the event of a leak in the steam generator, has been investigated. Ingress of high-pressure steam or water into sodium causes a vigorous exothermic reaction and high temperatures ( $\sim 1400$ to $1700 \mathrm{~K}$ ) in the vicinity of the leak. To ensure safe and reliable operation of sodium-heated steam generators, systems are incorporated for rapid detection of sodium-water reaction (e.g., oxygen and hydrogen meters in the sodium and cover gas), pressure relief (e.g., rupture discs), and cleanup of the reaction products (e.g., cold traps). However, the steam generator tubes must have sufficient resistance to wastage to 
provide adequate time for detection of a small leak and shutdown of the system to minimize damage to adjacent tubes.

Three distinct damage mechanisms have been postulated during sodiumwater reactions. A turbulent flame, which rapidly penetrates adjacent tubes, is associated with impingement wastage. For small leaks, damage to adjacent tubes may not accur; however, the leaking tube will undergo self-wastage. Higher than normal corrosion rates for system materials can also result from circulation of reaction products (i.e., sodium oxide and hydroxide) through the system. Considerable research effort has been expended to develop a quantitative understanding of wastage damage and sodium-water reactions $106,118,119$ since the phenomena were encountered in the FERMI steam generators. Investigators at Atomic Power Development Associates (APDA) performed numerous wastage experiments and provided the first quantitative data for damage rates associated with small leaks.112 The results showed that leak rate, tube spacing, and sodium temperature were important variables in the wastage process. In general, the wastage rate of a material in stagnant sodium increases with an increase in the leak rate over a wide range $(\mathrm{e} . \mathrm{g} ., 0.005$ to $500 \mathrm{~g} / \mathrm{s})$, whereas in flowing sodium, the wastage rate reaches a maximum at a leak rate of $\sim 5 \mathrm{~g} / \mathrm{s}$ and then decreases at higher leak rates. 112 The maximum penetration rate for $\mathrm{Fe}-2 \frac{1}{4} \mathrm{Cr}-1 \mathrm{Mo}$ steel in flowing sodium was $\sim 80 \mu \mathrm{m} / \mathrm{s}$ at $588 \mathrm{~K}$. The penetration rate decreases with either an increase in the leak-to-target distance (tube spacing) or a decrease in the sodium temperature. $112,116,117$

Several theories have been developed that provide insight into the phenomenon of impingement wastage and a basis for correlation and extrapolation of results obtained from different experimental facilities. Experimental observations of material wastage have been explained on the basis of combustion-flame theory.113,116 Another approach utilizes the kinetics of the sodium-water reaction to calculate the reaction-jet temperature as a function of leak rate, tube spacing, and sodium temperature. 117 Wastage rates based upon calculated jet temperatures are shown in Fig. 37.

The relative wastage resistance of Type 304 stainless steel, Alloy 800, and $\mathrm{Fe}-2 \frac{1}{4} \mathrm{Cr}-1 \mathrm{Mo}$ steel from water-injection tests is shown in Tables III 116 and IV. 118,119 The results indicate that Alloy 800 has a greater resistance to wastage than austenitic stainless steel and that the latter material is more resistant than ferritic steels. The resistance of Alloy 800 and Type 304 stainless steel increases markedly as the temperature decreases; however, the wastage rate of the $\mathrm{Fe}-2 \frac{1}{4} \mathrm{Cr}-1 \mathrm{Mo}$ steel does not exhibit a large temperature dependence. Another study on Alloy 800 and the $\mathrm{Fe}-2 \frac{1}{4} \mathrm{Cr}-1 \mathrm{Mo}$ steel at 616 and $783 \mathrm{~K}$, with a water-injection rate of $0.5 \mathrm{ml} / \mathrm{s}$ and a jetto-specimen distance of $20 \mathrm{~mm}$, yielded similar results. 14

With a relatively large tube spacing $(\succsim 12.5 \mathrm{~mm})$ and low leak rates ( $₫ 0.05 \mathrm{~g} / \mathrm{s})$, impingement wastage may not occur; the primary mode of damage then involves self-wastage. Under these conditions, small leaks frequently plug from the buildup of reaction products in and immediately around the defect. However, small leaks that self-plug can spontaneously open and grow.114-116 A plausible mechanism for unplugging involves transport of sodium to the steam side of the tube and the formation of sodium hydroxide, 


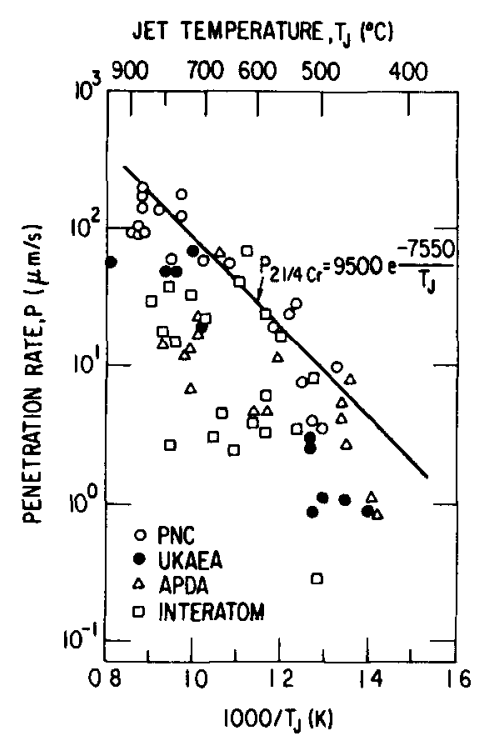

(a)

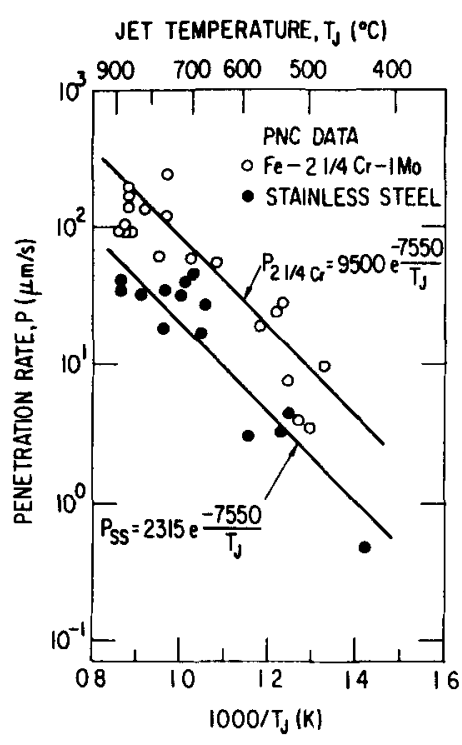

(b)

Fig. 37. Log Penetration Rate versus Reciprocal Jet Temperature for (a) $\mathrm{Fe}-2 \frac{1}{4} \mathrm{Cr}-1 \mathrm{Mo}$ Steel and (b) $\mathrm{Fe}-2 \frac{1}{4} \mathrm{Cr}-1$ Mo Steel and Stainless Steel (Ref. 117). ANL Neg. No. 306-79-515.

TABLE III. Wastage Resistance of Candidate Materials Relative

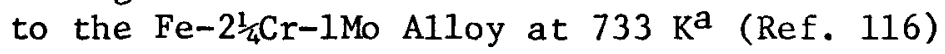

\begin{tabular}{|c|c|c|}
\hline \multirow[b]{2}{*}{ Material } & \multicolumn{2}{|c|}{ Sodium Temperature } \\
\hline & $733 \mathrm{~K}$ & $613 \mathrm{~K}$ \\
\hline $\mathrm{Fe}-2 \frac{1}{4} \mathrm{Cr}-1 \mathrm{Mo}$ & 1 & 2.5 \\
\hline Type 304 SS & 4 & 30 \\
\hline Alloy 800 & 6 & 100 \\
\hline
\end{tabular}


TABLE IV. Penetration Rate and Comparative Wastage Resistance of Candidate Materials ${ }^{\mathrm{a}}$ (Refs. 118 and 119)

\begin{tabular}{lccc}
\hline Material & $\begin{array}{c}\text { Penetration Rate, } \\
\mathrm{mm} \mathrm{s}\end{array}$ & $\begin{array}{c}\text { Mass Loss, } \\
\mathrm{g}\end{array}$ & Resistance Ratio \\
\hline Fe-2 $\frac{1}{4} \mathrm{Cr}-1$ Mo & $2.5 \pm 0.3 \times 10^{-3}$ & 0.356 & 1.0 \\
Fe-9Cr-1Mo & $2.1 \pm 0.6 \times 10^{-3}$ & 0.256 & 1.2 \\
Type $316 \mathrm{sS}$ & $8.0 \pm 3.1 \times 10^{-4}$ & 0.121 & 4.0 \\
Alloy 800 & $6.3 \pm 3.1 \times 10^{-4}$ & 0.0144 & 5.2 \\
\hline
\end{tabular}

${ }^{a}$ All tests performed with controlled sodium-water reaction flames at temperatures between 1173 and $1273 \mathrm{~K}$.

which attacks the base metal around the defect. The corrosion process eventually dislodges the plug and leakage of steam into the sodium occurs at a high rate.

Often, small leaks are present for an extended period of time and then rapid1y increase in size.113-116 The relationship between the initial leak rate and the time for sudden enlargement is shown in Fig. 38. The two curves for $\mathrm{Fe}-2 \frac{1}{4} \mathrm{Cr}-1 \mathrm{Mo}$ steel are based upon different leak geometries. The French data were obtained for leaks produced by fatigue cracking, whereas in the US study, the leaks were produced by drilling and swaging the tube. The results indicate that the self-wastage rate for austenitic stainless steel is higher than that of the $\mathrm{Fe}-2 \frac{1}{4} \mathrm{Cr}-1$ Mo alloy at high leak rates, but is lower at very low leak rates. The difference in the self-wastage behavior of the two materials under high-leak-rate conditions has been attributed to the poor thermal conductivity of the stainless steel.116 A relatively low thermal conductivity would result in a higher temperature, and consequently a higher wastage rate. When the leak rate is very low, the heat-generation rate is small for both materials and the wastage rate is determined primarily by the kinetics of the corrosion process. The sudden enlargement of small leaks has been explained on the basis of caustic attack of the steel.115,116 As the leak continues, a conical pit forms in the tube wall. When the pit reaches the steam side, the cross-sectional area of the leak changes rapidly from that of the original defect and gives rise to the observation of a sudden increase in the leak rate.

\section{B. Thermal-striping Phenomena}

Thermally induced cylic straining should be considered in the design of components that operate at elevated temperatures. Solar plants will undergo at least one major startup and shutdown cycle per day, with the likelihood of additional thermal cycles imposed by intermittent cloud cover and unscheduled maintenance and repair. Thus, critical structural components may be expected to accumulate tens of thousands of thermal-strain cycles over a 30-year design life. In addition, rapid thermal-strain cycles can occur in 


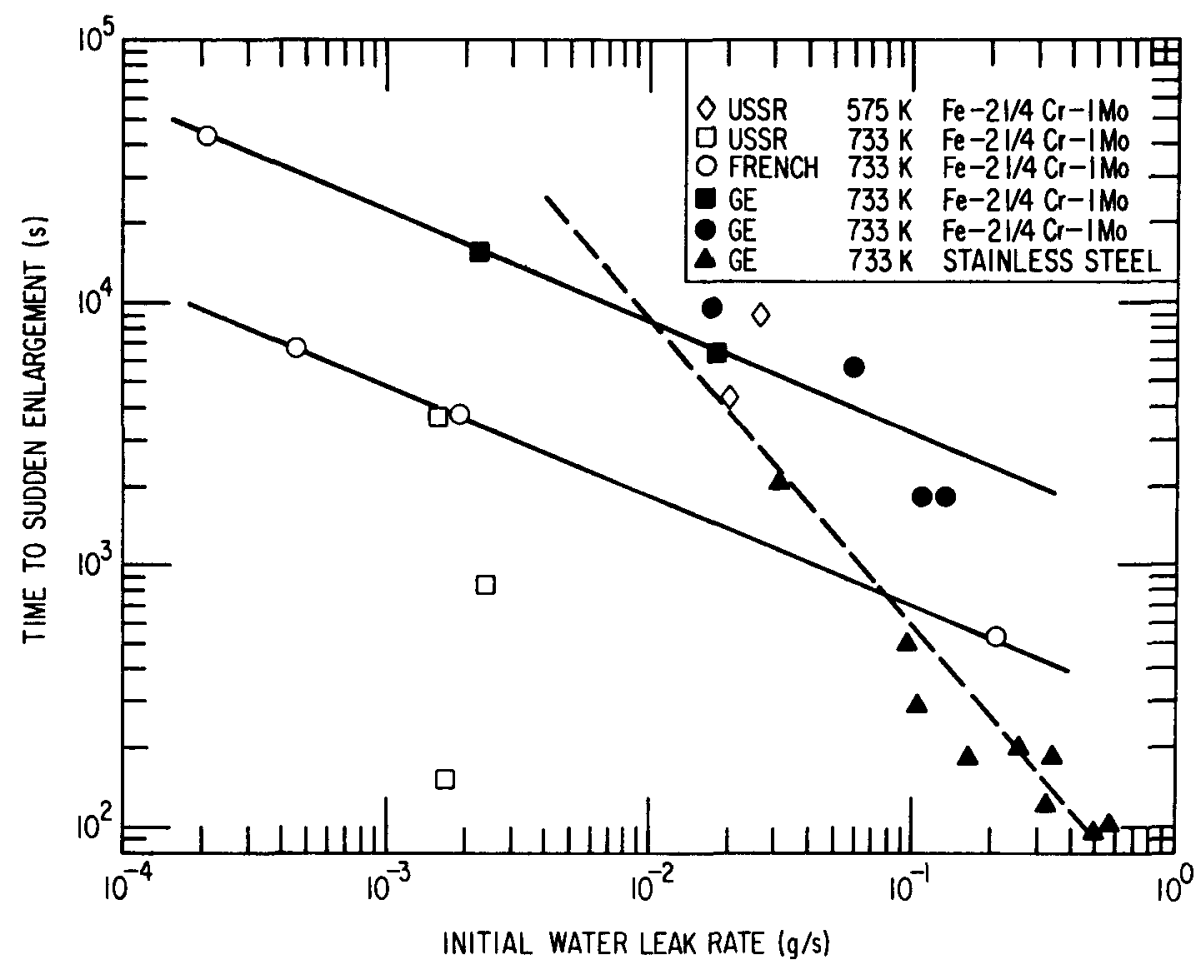

Fig. 38. Self-enlargement of Microleaks with Time (Ref. 116). ANL Neg. No. 306-79-516.

liquid-sodium heat-transport systems from turbulent mixing of sodium at different temperatures, a phenomenon termed "thermal striping". For example, the outlet temperatures of the sodium in adjacent fuel assemblies in fastbreeder reactors may differ by up to $100 \mathrm{~K}$. The rapid mixing of sodium may, therefore, result in substantial temperature fluctuations on surfaces of upper internals, or the above-core structure, in the reactor. In solar central-receiver power plants, differences in sodium outlet temperature could occur from nonuniform absorption of heat in various regions of the central receiver. The frequency of the strain cycles due to thermal striping is typically of the order of $1 \mathrm{~Hz}$; therefore, $10^{8}$ or more cycles may be accumulated over the service life of power-plant components.

Under thermal striping conditions, the largest strain range is experienced at the surface of components. Even relatively small temperature changes of $\sim 50$ to $100 \mathrm{~K}$ can cause surface yielding and initiate surface cracks. In the absence of additional mechanical loads or constraints the propagation of a crack depends on the stress-strain field in the bulk material induced by the temperature transient and propagation becomes increasingly difficult as significant crack penetration occurs.120 Component failure analysis under thermal-striping conditions is complex and requires data on strain-controlled fatigue properties in the high-cycle regime and crackpropagation rates in materials in both sodium and air environments. 


\section{RECOMMENDATIONS FOR FUTURE WORK}

Information on the behavior of materials in a high-temperature sodium environment has increased significantly during the past 15 years. An adequate data base for metallic- and nonmetallic-element transfer has been developed for sodium circuits constructed of austenitic stainless stee1s (Types 304,316 , and 321 ) and the Fe-2 $\frac{1}{4} \mathrm{Cr}-1$ Mo ferritic steel. Quantitative data on the compositional and microstructural changes in these materials as well as correlations between the corrosion rate and temperature, sodium purity, and sodium velocity have been obtained. Additional compatibility data are required to augment the data base for Alloy 800 and Fe-9Cr-1Mo ferritic steel relative to their performance in a high-temperature sodium environment.

Ongoing LMFBR programs in this country and abroad will continue to provide information on the effect of sodium environment on the mechanical properties of structural materials. It is hoped that these programs will provide the following results:

1. Longer-term creep-rupture data on sodium-exposed materials to confirm extrapolations of short-term results.

2. Longer-term fatigue, creep-fatigue, and crack-propagation data obtained from tests in well-characterized flowing sodium. The results can be used to evaluate and improve existing models for damage accumulation in materials under cyclic-loading conditions and to distinguish "true" deformation properties from environmental effects that arise during oxidation of specimens in an air environment.

3. Fatigue and creep-fatigue properties of weldments in a sodium environment after long-term sodium exposure and thermal aging.

4. High-cycle ( $(\mathrm{Hz})$ fatigue properties of materials to provide a more quantitative data base to evaluate the effects of "thermal striping" and flow-induced vibration on component performance.

A larger data base coupled with more quantitative deformation models, failure criteria and component design rules will result in a better assessment of performance limits and component reliability.

\section{ACKNOWLEDGMENTS}

We wish to thank the various authors and copyright owners for permission to reproduce information contained in several of the figures in this review.

\section{REFERENCES}

1. K. Natesan, 0. K. Chopra, and T. F. Kassner, "Compatibility of $\mathrm{Fe}-2 \frac{1}{4}$ wt $\% \mathrm{Cr}-1$ wt $\%$ Mo Steel in a Sodium Environment," Nuc1. Techno1. 28, 441 (1976). 
2. J. L. Krankota and J. S. Armijo, "The Kinetics of Decarburization of $2 \frac{1}{4} \% \mathrm{Cr}-1 \%$ Mo Steel in Sodium," Nucl. Techno1. 24, 225 (1974).

3. K. Matsumoto, Y. Ohta, T. Kataoka, S. Yagi, K. Suzuke, T. Yukitoshi, T. Moroishi, K. Yoshikawa, and Y. Shida, "Carbon Transfer Behavior of Materials for Liquid-Metal Fast Breeder Reactor Steam Generators," Nuc1. Techno1. 28, 452 (1976).

4. J. L. Krankota and J. S. Armijo, "Influence of High Temperature Thermal and Sodium Exposure on the Mechanical Properties and Composition of Low Carbon $2 \frac{1}{4} \mathrm{Cr}-1$ Mo Steel," Proc. Symp. on Low Carbon and Stabilized $2 \frac{1}{4} \% \mathrm{Cr}-1 \%$ Mo Steels, American Society for Meta1s, Metals Park, Ohio, p. 57 (1973).

5. D. L. Sponseller, M. Semchyshen, and P. J. Grobner, "Effect of Low Carbon Contents and Exposures to Liquid Sodium on Elevated Temperature Behavior of $2 \frac{1}{4}$ wt \% Cr-1 wt \% Mo Steel, "Proc. Symp. on Low Carbon and Stabilized $2 \frac{1}{4} \% \mathrm{Cr}-1 \%$ Mo Steels, American Society for Metals, Metals Park, Ohio, p. 73 (1973).

6. J. L. Krankota and K. D. Challenger, "Carbon Transport and Material Property Degradation in a Model of the Clinch Breeder Reactor Secondary Sodium System," Proc. Int1. Conf. on Liquid Metal Technology in Energy Production, CONF-760503-P2, 819 (1976).

7. M. Besson, P. Baque, L. Champeix, J. R. Donati, C. Oberlin, and P. Saint-Paul, "Carbon Transfer Between $2 \frac{1}{4} \mathrm{Cr}-1$ Mo Alloy and Austenitic Steels," Proc. Intl. Conf. on Liquid Metal Technology in Energy Production, CONF-760503-P2, 834 (1976).

8. H. Atsumo, S. Yuhara, A. Maruyama, S. Kanoh, N. Aoki, and K. Mochizuki, "Sodium Compatibility and Corrosion Tests for Component Materials," Proc. Int1. Conf. on Liquid Metal Technology in Energy Production. CONF760503-P2, 849 (1976).

9. O. K. Chopra, K. Natesan, and T. F. Kassner, "Compatibility of Ferritic Steels in a Sodium Environment," Proc. Int1. Conf. on Liquid Metal Technology in Energy Production, CONF-760503-P2, 730 (1976).

10. G. Menken, E. D. Grosser, and E. Te Hessen, "Corrosion and Creep Behavior of Ferritic Cr-Alloyed Steels in Sodium," Proc. Int1. Conf. on Ferritic Steels for Fast Reactor Steam Generators, BNES, London, p. 264 (1978).

11. C. Tyzack and A. W. Thorley, "Review of Corrosion and Carbon Transport Behavior of Ferritic Materials Exposed to Sodium," Proc. Intl. Conf. on Ferritic Steels for Fast Reactor Steam Generators, BNES, London, p. 241 (1978).

12. A. W. Thorley and C. Tyzack, "Corrosion Behavior of Steels and Nicke1 Alloys in High Temperature Sodium," Proc. Symp. Alkali Metal Coolants, IAEA, Vienna, p. 97 (1967). 
13. A. W. Thorley and C. Tyzack, "Corrosion and Mass Transport of Steel and Nickel Alloys in Sodium Systems," Proc. Int1. Conf. Liquid Alkali Metals, BNES, Nottingham, p. 257 (1973).

14. J. S. Armijo, J. L. Krankota, C. N. Spalaris, K. M. Horst, and F. E. Tippets, "Materials Selection and Expected Performance in Near Term LMFBR Steam Generators," Int1. Conf. on Fast Reactor Power Stations, BNES, London, p. 189 (1974).

15. J. Sannier, O. Konovaltschikoff, D. Leclercq, and R. Darras, "Compatibility of Ferritic Steels with Liquid Sodium at High Temperatures," Conf. on Effects of Environment on Materials Properties in Nuclear Systems, BNES, London, p. 155 (1971).

16. W. J. Anderson, G. S. Sheffield, and A. J. Berkle, Development of Ferritic Steels for High Temperature Sodium Service, Part II, NAA-SR7544, Atomic International, California (1963).

17. A. W. Thorley, C. Tyzack, B. Longson, and A. C. Raine, "Some Aspects of the Mass Transfer Behavior in Sodium of Steels of Interest in UK Fast Reactor Program," Proc. Int1. Conf. on Liquid Metal Technology in Energy Production, CONF-760503-P2, p. 685 (1976).

18. Summary Report--Sodium Mass Transfer Program, "Effects of Sodium Exposure on the Corrosion and Strength of Stainless Stee1s," GEAP-10394 (1971).

19. W. C. Hayes and 0. C. Shepard, "Corrosion and Decarburization of the Ferritic Chromium-Molybdenum Steels in a Sodium Coolant System," NAASR-2973, Atomic International (1958).

20. A. G. Crouch and P. R. Bussey, "Corrosion of Ferritic Steels in Flowing Sodium," Proc. Int1. Conf. on Ferritic Steels for Fast Reactor Steam Generators, BNES, London, p. 258 (1978).

21. 0. K. Chopra, K. Natesan, and T. F. Kassner, "Compatibility of Fe-9 Cr-Mo Ferritic Steels in a Sodium Environment," ANL Report, to be published.

22. C. Spalaris, K. D. Challenger, D. Dutina, and P. Roy, "Sodium Heated Steam Generators: Near Term and Projected Information Needs--Ferritic Steels," Proc. Int1. Conf. on Ferritic Steels for Fast Reactor Steam Generators, BNES, London, p. 55 (1978).

23. T. Yukitoshi, T. Moroishi, I. Koizumi, T. Abe, K. Yoshikawa, and Y. Shida, "Comparison of Various Chromium-Molybdenum Low Alloy Steels for Liquid Metal Fast Breeder Reactor Steam Generators," Nuc1. Techno1. 28, 506 (1976)..

24. K. W. Andrews, H. Hughes, and D. J. Dyson, "Constitution Diagrams for Cr-Mo-Steels," J. Iron and Steel Inst. 210, 337 (1972). 
25. W. Crafts and C. M. Offenhauer, "Carbides in Low Chromium-Molybdenum Steels," Trans. AIME 154, 361 (1943).

26. Keshin Kuo, "Carbides in Chromium, Molybdenum, and Tungsten Steels," J. Iron and Steel Inst. 173, 363 (1953).

27. R. L. Klueh, "Effect of Carbon on the Mechanical Properties of $2 \frac{1}{4} \mathrm{Cr}-1 \mathrm{Mo}$ Stee1," ORNL-4922 (1973).

28. W. R. Apblett, Jr. and M. Matejic, "Extra Low Carbon Ferritic Steels for High Temperature Sodium Service," Proc. Symp. on Low Carbon and Stabilized $2 \frac{1}{4} \% \mathrm{Cr}-1 \%$ Mo Steels, American Society for Metals, Metals Park, Ohio, p. 131 (1973).

29. G. V. Smith, "Elevated-Temperature Properties of Chromium-Molybdenum Steels," ASTM DS6 (1953).

30. R. H. Zeisloft, W. E. Leyda, and H. A. Domian, "Low Carbon $2 \frac{1}{4} \mathrm{Cr}-1 \mathrm{Mo}$ Stee1s," Proc. Symp. on Low Carbon and Stabilized $2 \frac{1}{4} \% \mathrm{Cr}-1 \%$ Mo Steels, American Society for Metals, Metals Park, Ohio, p. 37 (1973).

31. Program for the Development of Design Data LMFBR Steam Generator Materials, USDOE Rep. GEFR-00067-2, Genera1 Electric Company, Sunnyvale, CA (1978).

32. R. L. K1 ueh, "Creep-Rupture Properties of Decarburized and Aged $2 \frac{1}{4} \mathrm{Cr}-1$ Mo Stee1," ORNL-5292 (1977).

33. L. H. Kirschler, R. H. Hiltz, and S. J. Rodgers, "The Effect of High Temperature Sodium on the Mechanical Properties of Candidate Alloys for the LMFBR Program," USAEC Rep. MSAR 69-42, MSA Research Corporation, Evans City, PA (1969).

34. R. C. Andrews and L. H. Kirschler, "Design Properties of One Heat of $2 \frac{1}{4} \mathrm{Cr}-1 \mathrm{Mo}$ Steel and 316 Stainless Steel in High Temperature Air, Helium and Sodium Environments," USAEC Rep. MSAR 66-174, MSA Research Corporation, Evans City, PA (1966).

35. S. Yuhara and H. Atsumo, "Creep and Creep-Rupture Properties of $2 \frac{1}{4} \mathrm{Cr}-1$ Mo Steel for a Fast Breeder Reactor in High-Temperature Sodium," Proc. Intl. Conf. on Ferritic Steels for Fast Reactor Steam Generators, BNES, London, p. 300 (1978).

36. R. L. Klueh, "Thermal Aging Effects on the Mechanical Properties

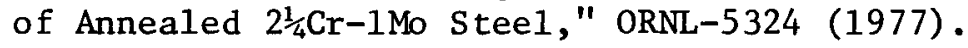

37. O. K. Chopra and K. Natesan, Mechanical Properties Test Data for Structural Materials Quarterly Progress Report for Period Ending April 30, 1978, ORNL-5416, p. 78. 
38. 0. K. Chopra and K. Natesan, Mechanical Properties Test Data for Structural Materials Quarterly Progress Report for Period Ending July 31, 1978, ORNL/BRP-78/2, p. 2.12.

39. C. R. Brinkman, M. K. Booker, J. P. Strizak, W. R. Corwin, J. L. Frazier, and J. M. Leitnaker, "Interim Report on the Continuous Cycling Elevated-Temperature Fatigue and Subcritical Crack Growth Behavior of $2 \frac{1}{4} \mathrm{Cr}-1$ Mo Steel," ORNL-TM-4993 (1975).

40. C. R. Brinkman, J. P. Strizak, M. K. Booker, and C. E. Jaske, "Timedependent Strain-controlled Fatigue Behavior of Annealed $2 \frac{1}{4} \mathrm{Cr}-1 \mathrm{Mo}$ Steel for Use in Nuclear Steam Generator Design," J. Nucl. Mater. 62, 181 (1976).

41. C. R. Brinkman, R. K. Williams, R. L. Klueh, and T. L. Hebble, "Mechanical and Physical Properties of $2 \frac{1}{4} \mathrm{Cr}-1$ Mo Steel in Support of Clinch River Breeder Reactor P1ant Steam Generator Design," Nuc1. Technol. 28, 490 (1976).

42. International Standard ISO 2604, Steel Products for Pressure Purposes, International Standards Organization, 1975.

43. D. S. Wood, A. B. Baldwin, F. W. Grounds, J. Wynn, E. G. Wilson, and J. Wareing, "Mechanical Properties Data on 9\% Cr Steel," Proc. Intl. Conf. on Ferritic Steels for Fast Reactor Steam Generators, BNES, London, p. 189 (1978).

44. T. Yukitoshi, K. Yoshikawa, K. Tokimasa, T. Kudo, Y. Shida, and Y. Inaba, "Development of $9 \mathrm{Cr}-2$ Mo Steel for Fast Breeder Reactor Steam Generators," Proc. Int1. Conf. on Ferritic Steels for Fast Reactor Steam Generators, BNES, London, p. 87 (1978).

45. G. C. Bodine, B. Chakravarti, C. M. Owens, B. W. Roberts, D. M. Vandergriff, and C. T. Ward, "A Program for the Development of Advanced Ferritic Alloys for LMFBR Structural Application," US-ERDA Report ORNL-Sub-4291/1 (1977).

46. G. V. Smith, "Evaluation of the Elevated Temperature Tensile and Creeprupture Properties of 3 to 9 Percent Chromium-Molybdenum Steels," ASTM DS58 (1975).

47. A. Thorley, B. Longson, and J. Prescott, "Effect of Exposure to Sodium on the Mechanical Properties and Structure of Some Ferritic, Austenitic and High Nickel Alloys," TRG-Report-1909 (1970).

48. D. S. Wood, "Effects of a Sodium Environment on the Mechanical Properties of Ferritic Steels," Proc. Int1. Conf. on Ferritic Steels for Fast Reactor Steam Generators, BNES, London, p. 293 (1978). 
49. W. Charnock, J. E. Cordwell, and P. Marshall, "The Influence of High Temperature Sodium on the Structure and Mechanical Properties of $9 \mathrm{Cr}$ Steel," Proc. Int1. Conf. on Ferritic Steels for Fast Reactor Steam Generators, BNES, London, p. 310 (1978).

50. D. S. Wood, G. F. Slattery, J. Wynn, M. D. Connaughton, and M. E. Lambert, "Preliminary Results of Effect of Environment on the Low Cycle Fatigue Behavior of Type 316 Stainless Steel and 9\% Cr Ferritic Steel," Conf. on Influence of Environment on Fatigue, London (1977).

51. K. Furukawa and I. Nihei, "Mass Transfer Phenomenon of the Austenitic Steels at High Temperature and High Flow Velocity," Proc. Int1. Conf. on Sodium Technology and Large Fast Reactor Design, ANL-7520, 143 (1968).

52. E. L. Zebroski, R. S. Young, F. A. Comprelli, and D. Dutina, "Effects of Mass Transfer, and of Changes in Properties, on Austenitic Steels in Flowing Sodium," Proc. Symp. Alkali Metal Coolants, Vienna, 195 (1966).

53. G. A. Whitlow, J. C. Cwynar, R. L. Miller, and S. L. Schrock, "Sodium Corrosion Behavior of Alloys for Fast Reactor Applications," Proc. Symp. on Chemical Aspects of Corrosion and Mass Transfer in Liquid Sodium, Detroit, 1 (1971).

54. P. A. Bague, L. J. Champeix, and E. T. Honnorat, "Compositional Changes in Austenitic Stainless Steels After Corrosion in Sodium at $700^{\circ} \mathrm{C}, "$ Proc. Symp. on Chemical Aspects of Corrosion and Mass Transfer in Liquid Sodium, Detroit, 299 (1971).

55. S. A. Shiels, C. Bagna11, S. L. Schrock, and S. J. Orbon, "The Influence of LMFBR Fuel Pin Temperature Profiles on Corrosion Rates," Proc. Int1. Conf. on Liquid Metal Technology in Energy Production, CONF-760503-P1, 386 (1976).

56. P. Roy and M. F. Gebhardt, "Corrosion and Mass Transport of Stainless Steels in Sodium Systems," GEAP-13548 (1969).

57. C. Bagna11 and D. C. Jacobs, "Relationships for Corrosion of Type 316 Stainless Steel in Liquid Sodium," WARD-NA-3045-23 (1975).

58. P. Roy, G. P. Wozadlo, and F. A. Comprelli, "Mass Transport and Corrosion of Stainless Steels in Flowing Sodium Systems at $1300^{\circ} \mathrm{F}$," Proc. Int1. Conf. on Sodium Technology and Large Fast Reactor Design, ANL-7520 (1968).

59. M. C. Rowland, D. E. Plumlee, and R. S. Young, "Sodium Mass Transfer XV, Behavior of Selected Steels Exposed in Flowing Sodium Test Loops," GEAP-4831 (1965).

60. W. F. Holcomb, "Carburization of Type 304 Stainless Steel in Liquid Sodium," Nucl. Eng. Des. 6, 264 (1967). 
61. M. Kolodney, "Carburization of Austenitic Stainless Steel by Sodium," Proc. Int1. Conf. on Sodium Technology and Fast Reactor Design, ANL-7520, 104 (1968).

62. N. P. Agapova, "The Behavior of Stainless Steel in Sodium Between 600$900^{\circ} \mathrm{C}, "$ Proc. Symp. Alkali Metal Coolant, Vienna, 85 (1966).

63. C. S. Campbell and C. Tyzack, "A Preliminary Model for the Carburization of Stainless Steel at High Temperatures in Sodium Containing Carbon at Unit Activity," Proc. Symp. Alkali Metal Coolant, Vienna, 159 (1966).

64. W. J. Anderson and G. V. Sneesby, "Carburization of Austenitic Stainless Steel in Liquid Sodium," NAA-SR-5282 (1960).

65. S. A. Shiels, C. Bagna11, and S. L. Schrock, "Interstitial Mass Trans-fer in Sodium Systems," Proc. Symp. on Chemical Aspects of Corrosion and Mass Transfer in Liquid Sodium, Detroit, 157 (1971).

66. E. D. Grosser, "Interstitial Element Movement in Potential Fuel Cladding Materials in Sodium," Proc. Symp. on Chemical Aspects of Corrosion and Mass Transfer in Liquid Sodium, Detroit, 199 (1971).

67. H. V. Borgstedt and E. D. Grosser, "Interstitial Element Movement of Austenitic Stainless Steels in Sodium," Proc. Intl. Conf. on Liquid Alkali Metals, BNES, 275 (1973).

68. S. L. Schrock, S. A. Shiels, and C. Bagnall, "Carbon and Nitrogen Transport in Sodium Systems," Proc. Int1. Conf. on Liquid Metal Technology in Energy Production, CONF-760503-P2, 809 (1976).

69. S. A. Shie1s, C. Bagnall, and S. L. Schrock, "Carbon Equilibrium Relationships for Austenitic Stainless Steels in a Sodium Environment," Nuc1. Techno1. 23, 273 (1974).

70. K. Natesan and T. F. Kassner, "Thermodynamic and Kinetic Aspects of Carbon Transport in Sodium-Steel Systems," J. Nucl. Mater. 37, 223 (1970).

71. K. Natesan and T. F. Kassner, "Thermodynamics of Carbon in Nicke1, Iron-Nickel and Iron-Chromium-Nickel Alloys," Met. Trans. 4, 2557 (1973).

72. R. B. Snyder, K. Natesan, and T. F. Kassner, "A Generalized Method of Computing Carbon-Diffusion Profiles in Austenitic Stainless Steels Exposed to a Sodium Environment," ANL-8015 (1973); also "Kinetics of Carburization-Decarburization Process of Austenitic Stainless Steels in Sodium," J. Nuc1. Mater. 50, 259 (1974).

73. R. B. Snyder, K. Natesan, and T. F. Kassner, "An Analysis of Carbon Transport in the EBR-II and FFTF Primary Sodium Systems," Proc. Int1. Conf. on Liquid Metal Technology in Energy Production, CONF-760503-P2, 826 (1976). 
74. K. Natesan and T. F. Kassner, "Monitoring and Measurement of Carbon Activity in Sodium Systems," Nuc1. Technol. 19, 46 (1973).

75. K. Natesan, T. F. Kassner, and Che-Yu Li, "Effect of Sodium on Mechanical Properties and Friction-Wear Behavior of LMFBR Materials," Reactor Technol. 15, 244 (1972).

76. L. H. Kirschler and R. C. Andrews, "Effect of High-Temperature Sodium on the Mechanical Properties of Candidate Alloys for the LMFBR Program," Proc. Intl. Conf. on Sodium Technology and Fast Reactor Design, ANL-7520, 41 (1968).

77. A. Thorley and C. Tyzack, "The Carburization of Stainless Steels in Sodium Containing Carbon Impurities and Its Effect on Mechanical Properties," Proc. Int1. Conf. on Effects of Environment on Materials Properties in Nuclear Systems, BNES, London, 143 (1971).

78. K. Natesan, D. L. Smith, T. F. Kassner, and 0. K. Chopra, "Influence of Sodium Environment on the Tensile Behavior of Austenitic Stainless Steels," ASME Symp. on Structural Material for Service and Elevated Temperatures in Nuclear Power Generation, MPC-1, 302 (1975).

79. O. K. Chopra and K. Natesan, "Representation of Elevated-Temperature Tensile Behavior of Type 304 Stainless Steel in a Sodium Environment," J. Eng. Mater. Technol. 99, 366 (1977).

80. K. Natesan, O. K. Chopra, and T. F. Kassner, "Influence of Sodium Environment on the Uniaxial Tensile Behavior of Titanium Modified Type 316 Stainless Steel," J. Nuc1. Mater. 73, 137 (1978).

81. W. T. Lee, "Biaxial Stress-Rupture Properties of Austenitic Stainless Steels in Zirconium-Gettered Sodium," USAEC Report NAA-SR-12353, Atomics International (1967).

82. D. F. Atkins, "Stress-Rupture Behavior of Types 304 and 316 Stainless Steels Cladding in High-Temperature Static Sodium," USAEC Report AIAEC-12976, Atomics International (1970).

83. J. H. Shively, D. F. Atkins, and W. T. Lee, "Creep Under High Heat Flux and Stress-Rupture Properties of Austenitic Stainless Steels in Elevated Temperature Sodium," Proc. Intl. Conf. on Sodium Technology and Large Fast Reactor Design, ANL-7520, 74 (1968).

84. P. N. Flagella, J. A. Denne, and S. L. Schrock, Mechanical Properties Test Data for Structural Materials Ouarterly Progress Report for Period Ending January 31, 1978, ORNL-5380, 186.

85. K. Natesan, O. K. Chopra, and T. F. Kassner, "Effect of Sodium on the Creep-Rupture Behavior of Type 304 Stainless Stee1," Proc. Int1. Conf. on Liquid Metal Technology in Energy Production, CONF-760503-P1, 338 (1976). 
86. L. M. T. Hopkin and L. H. Taylor, "Creep Properties of Cr-Ni-Mo Austenitic Stainless Steel in Relation to Structure," J. Iron Steel Inst. $\underline{205}, 17$ (1967).

87. P. D. Goode11, T. M. Cullen, and J. W. Freeman, "The Influence of Nitrogen and Certain Other Elements on the Creep-Rupture Properties of Wholly Austenitic Type 304 Stee1," Trans. ASME 89, 517 (1967).

88. P. G. Stone, "High Temperature Properties of Steels," Proc. Joint Conf. Organized by the British Iron and Steel Research Association and the Iron and Steel Institute, 505 (1966).

89. B. Weiss and R. Stickler, "Phase Instabilities During High Temperature Exposure of 316 Austenitic Stainless Stee1," Met. Trans. 3, 851 (1972).

90. G. F. Tisinai, J. K. Stanley, and C. H. Samans, "Effect of Nitrogen on Sigma Formation in $\mathrm{Cr}-\mathrm{Ni}$ Steels at $1200^{\circ} \mathrm{F}\left(650^{\circ} \mathrm{C}\right), "$ Trans. AIME, 200 , 1259 (1954).

91. D. L. Smith, G. J. Zeman, K. Natesan, and T. F. Kassner, "Influence of Low-Cycle Fatigue Behavior of Type 304 and 316 Stainless Steels," Proc. Int1. Conf. Liquid Metal Technology in Energy Production, CONF760503-P1, 359 (1976).

92. D. L. Smith, K. Natesan, T. F. Kassner, and G. J. Zeman, "Effects of Sodium on the Low-Cycle Fatigue Behavior of Austenitic Stainless Steels," ASME Symp. on Structural Materials for Service at Elevated Temperatures in Nuclear Power Generation, MPC-1, 290 (1975).

93. G. J. Zeman and D. L. Smith, "Low Cycle Fatigue Behavior of Type 304 and 316 Stainless Steels Tested in Sodium at $550^{\circ} \mathrm{C}, "$ Nucl. Technol. 42, 82 (1979).

94. P. N. Flagella, J. A. Denne, and S. L. Schrock, Mechanical Property Test Data for Structural Materials Quarterly Progress Report for Period Ending April 30, 1978, ORNL-5416, 239.

95. P. N. Flagella and J. R. Kahrs, "Low-Cycle Fatigue Testing in Flowing Sodium at Elevated Temperatures," Proc. Intl. Conf. on Liquid Metal Technology in Energy Production, CONF-760503-P1, 353 (1976).

96. L. A. James and R. L. Knecht, "Fatigue-Crack Propagation Behavior of Type 304 Stainless Steel in a Liquid Sodium Environment," Met. Trans. 6A, 109 (1975).

97. S. F. Pugh, "A Status Review of Alloy 800 in Nuclear Applications," Proc. BNES Conf., University of Reading, 1 (1974).

98. Huntington Alloy--International Nickel Company Data Package, "Incoloy Alloy 800 Data for Use in Design of Gas Cooled and Liquid Metal Fast Reactor," (1975). 
99. F. A. Mazandarany and P. L. Rittenhouse, "Effect of Service Environment on the Behavior of High Temperature Gas Cooled Reactor Steam Generator Structural Materials," Nucl. Technol. 28, 406 (1976).

100. H. G. A. Bates, W. Betteridge, R. H. Cook, L. W. Graham, and D. F. Lupton, "The Behavior of Metals in High-Temperature Reactor Helium for Steam Generators," Nucl. Technol. 28, 424 (1976).

101. S. Vandeth and R. L. Hemmings, "Materials in CANDU Steam Generators from the Designer's Point of View," Nucl. Technol. 28, 328 (1976).

102. L. Stieding, "Application of A1loy 800 in PWR's," Proc. of BNES Conf., University of Reading, 345 (1974).

103. A. W. Thorley, "A Review of the Behavior of Alloy 800 in Liquid Sodium," Proc. BNES, Conf. University of Reading, 185 (1974).

104. H. U. Borgstedt, G. Frees, and A. Marin, "Corrosion and Carburization of Incoloy 800 in Liquid Sodium up to $973 \mathrm{~K}$," in Alloy 800 , W. Betteridge et al. (eds.), North Holland Publishing Co., 291 (1978).

105. D. W. Sandusky, J. S. Armijo, and W. J. Wagner, "Influence of Long Term Sodium Exposure on the Composition and Microstructure of Austenitic Alloys," J. Nuc1. Mater. 46, 225 (1973).

106. L. Champeix, "High Temperature Corrosion and Mechanical Properties in Sodium Environment," in Alloy 800, W. Betteridge et al. (eds.), North Holland Publishing Co., 283 (1978).

107. P. Bague, L. Champeix, A. Lafon, and E. Sermet, "Some Aspects of Corrosion of Austenitic Steels in Flowing Sodium," Proc. Intl. Conf. on Liquid Alkali Metals, BNES, London, 223 (1973).

108. Sodium Technology Program--Progress Report, WARD-3045T1-3, Westinghouse Electric Corporation, Advance Reactors Division, Madison (1972).

109. H. Bohm and H. Schneider, "Stress Rupture and Creep Behavior of Austenitic $\mathrm{Cr}-\mathrm{Ni}$ Steels in the Presence of Na," J. Nucl. Mater. 24, 188 (1967).

110. R. S. Fidler, "The Effect of Liquid Sodium on the Creep and Rupture Properties of Alloy 800 ," in Alloy 800, W. Betteridge et al. (eds.), North Holland Publishing Co., 297 (1978).

111. J. E. Cordwell and R. D. Nicholson, "Effect of Liquid Sodium on the Tensile and Creep-Rupture Properties of Incoloy 800: A Preliminary Study," RD/B/N3195, Centra1 Electricity Generating Board, Berkeley Nuclear Laboratories (1975). 
112. H. V. Chamberlain, J. H. Coleman, E. C. Kovacic, and A. A. Shoudy, "Wastage of Steam-Generator Materials by Sodium-Water Reactions," Proc. Intl. Conf. on Sodium Technology and Large Fast Reactor Design, ANL-7520, 384 (1968).

113. D. A. Greene, "Sodium-Water Wastage and Reactions Program Performed by General Electric in Support of the US-AEC LMFBR Steam Generator Development," IAEA Study Group, "Steam Generators for LMFBRs," Interatom, Bensburg, 1974.

114. F. A. Kozlov, G. P. Sergeev, A. R. Sednev, and V. M. Makarov, "Studies on Some Problems of Leaks in Sodium-Water Steam Generators," Proc. Int1. Conf. on Liquid Metal Technology in Energy Production, CONF-760503-P1, 202 (1976).

115. D. W. Sandusky, "Sma11 Leak Shutdown, Location and Behavior of LMFBR Steam Generators," Proc. Int1. Conf. on Liquid Metal Technology in Energy Production, CONF-760503-P1, 226 (1976).

116. D. A. Greene, "Small Leak Damage and Protection Systems in Steam Generators," Proc. Intl. Conf. on Liquid Metal Technology in Energy Production, CONF-760503-P1, 233 (1976).

117. K. Tregonning, "Calculation of Wastage by Sma11 Water Leaks in Sodium Heated Steam Generators," Proc. Int1. Conf. on Liquid Metal Technology in Energy Production, CONF-760503-P1, 218 (1976).

118. R. N. Newman, A. R. Pugh, and C. A. Smith, "Explosive Interaction between Sodium and Water, and Material Wastage in the Vicinity of Leaks in Sodium Water Heat Exchangers," Conf. Liquid Alkali Metals, BNES, 85 (1973).

119. R. N. Newman and C. A. Smith, "Sodium/Water Combustion and the Chemistry of Wastage at Sodium/Water Leak Sites," J. Nucl. Mater. 2, 173 (1974).

120. B. Tomkins, "The Interpretation of Elevated Temperature Fatigue Data," presented at Int1. Conf. on Fatigue Testing and Design, London (1976). 
APPENDIX A

List of Abbreviations

AI

ANL

APDA

B\&W

$\mathrm{CE}$

CEA

EDF

FW

GA

GE

GFK

IHI

INTERATOM

MRL

MSAR

ORNL

PNC

SUMITOMO

UKAEA

WARD
Atomics International, Canoga Park, California

Argonne National Laboratory, Argonne, Illinois

Atomic Power Development Associates, Inc., Detroit, Michigan

Babcock \& Wilcox Company Research Center, Alliance, Ohio

Combustion Engineering, Inc., Windsor, Connecticut

Commissariat al 1'Energie Atomique, Cadarache, France

Electricite de France, Les Renardieres, France

Foster Wheeler Corporation, Livingston, New Jersey

General Atomic Company, San Diego, California

General Electric Company, Sunnyvale, California

Gesel1schaft fur Kernforschung, Kar1sruhe, West Germany

Ishikawajima-Harima Heavy Industries Co., Yokohama City, Japan

Internationale Atomreaktorbau Bmbh, Bensberg, Germany

C1imax Molybdenum Company of Michigan Research Laboratory, Ann Arbor, Michigan

Mines Safety Appliances Research Corporation, Evans City, Pennsylvania

Oak Ridge National Laboratory, Oak Ridge, Tennessee

Power Reactor and Nuclear Fuel Development Corporation, Tokyo, Japan

Sumitomo Metal Industries, Ltd., Amagasaki, Japan

United Kingdom Atomic Energy Authority, Risley, UK

Westinghouse Advanced Reactor Division, Madison, Pennsylvania 


\section{APPENDIX B}

Table B-I. Temperature Conversion Table

\begin{tabular}{rrrrrr}
\hline $\mathrm{K}$ & ${ }^{\circ} \mathrm{C}$ & ${ }^{\circ} \mathrm{F}$ & \multicolumn{1}{c}{$\mathrm{K}$} & ${ }^{\circ} \mathrm{C}$ & ${ }^{\circ} \mathrm{F}$ \\
\hline 300 & 27 & 80 & 725 & 452 & 845 \\
325 & 52 & 125 & 750 & 477 & 890 \\
350 & 77 & 170 & 775 & 502 & 935 \\
375 & 102 & 215 & 800 & 527 & 980 \\
400 & 127 & 260 & 825 & 552 & 1025 \\
425 & 152 & 305 & 850 & 577 & 1070 \\
450 & 177 & 350 & 875 & 602 & 1115 \\
475 & 202 & 395 & 900 & 627 & 1160 \\
500 & 227 & 440 & 925 & 652 & 1205 \\
525 & 252 & 485 & 950 & 677 & 1250 \\
550 & 277 & 530 & 975 & 702 & 1295 \\
575 & 302 & 575 & 1000 & 727 & 1340 \\
600 & 327 & 620 & 1025 & 752 & 1385 \\
625 & 352 & 665 & 1050 & 777 & 1430 \\
650 & 377 & 710 & 1075 & 802 & 1475 \\
675 & 402 & 755 & 1100 & 827 & 1520 \\
700 & 427 & 800 & 1125 & 852 & 1565 \\
\hline
\end{tabular}


Distribution for ANL-79-36

Internal:

J. J. Roberts

B. R. T. Frost

O. K. Chopra

A. A. Jonke

T. F. Kassner (4)
S. Majumdar

K. Natesan

W. E. Ruther

W. J. Shack

D. L. Smith

C. C. Stone
J. Y. N. Wang

A. B. Krisciunas

ANL Contract File

ANL Libraries (5)

TIS Files (6)

\section{External:}

DOE-TIC, for distribution per UC-62c (347)

Manager, Chicago Operations and Regional office, DOE

Chief, Office of Patent Counsel, DOE-CORO

President, Argonne Universities Association

Materials Science Division Review Committee:

E. A. Aitken, General Electric Co., Sunnyvale

G. S. Anse11, Rensselaer Polytechnic Inst.

R. W. Balluffi, Massachusetts Inst. Technology

R. J. Birgeneau, Massachusetts Inst. Technology

S. L. Cooper, U. Wisconsin

C. Laird, U. Pennsylvania

M. T. Simnad, General Atomic

C. T. Tomizuka, U. Arizona

A. R. C. Westwood, Martin Marietta Labs.

Div. of Central Solar Technology, USDOE, Washington:

G. W. Braun

M. U. Gutstein

L. Melamed

J. E. Rannels

J. Weisiger

Div. of Solar Technology, USDOE, San Francisco Operations Office:

R. W. Hughey

S. D. Elliott

R. N. Schweinberg, Solar $10 \mathrm{MW}$ Project Office, USDOE, E1 Monte, Calif.

E. Katz, Aerospace Corp., Los Angeles

E. Weber, Arizona Public Service Co., Phoenix

0. W. Durrant, Babcock \& Wilcox Co., Barberton

E. Y. Lam, Bechtel Nationa1, Inc., San Francisco

C. R. Bozzuto, Combustion Engineering, Windsor

J. Bigger, Electric Power Research Inst.

Foster Wheeler Development Corp., Livingston, N. J.:

I. Berman

R. Zoschak

General Atomic:

J. Schuster

J. Kaar

General Electric Co., San Jose:

C. N. Spalaris

P. Roy

J. Elsner, General Electric Co., Schenectady

W. F. Brehm, Hanford Engineering Development Lab.

T. Heaton, Martin Marietta Aerospace Corp., Denver 
R. Hallet, McDonnell Douglas Astronautics Co., Huntington Beach Rockwe11 Internationa1, Canoga Park:

T. H. Springer

J. Page

Solar Energy Research Institute:

F. Kreith

B. Butler

S. Pohlman

J. Reeves, Southern California Edison Co., Rosemead Oak Ridge National Laboratory:

J. H. DeVan

P. Patriarca

J. Bugge, Westinghouse Electric Corp., Pittsburgh

Westinghouse Electric Corp., Madison, Pa.:

W. E. Ray

F. G. Arcella

D. S. Griffin

S. A. Shiels

CRBRP Program Office, USDOE, Oak Ridge:

S. L. Schrock

E. A. Wright

J. R. Hunter, Div. Reactor Research and Technology, USDOE

E. E. Hoffman, Oak Ridge Operations Office, USDOE

A. F. Baker, Bonn, Germany

Sandia Laboratories, Livermore:

J. F. Banas

J. A. Leonard

M. J. Davis

J. Munford

W. B. Jones

W. J. Spencer

A. N. B1ackwel1

B. F. Murphey

C. S. Hoyle

W. D. Zinke

D. M. Schuster

M. W. Mote

D. B. Dawson

J. D. Swearengen

R. A. Baroody

C. S. Salvage

D. E. Gregson

C. M. Tapp

R. C. Wayne

W. G. Wilson

J. J, Bartel

K. W. Battleson

E. T. Cull

C. W. Moore

A. C. Skinrood

L. N. Tallerico

J. D. Gilson

L. G. Radosevich

J. W. Liebenberg

F. J. Cupps 